\title{
EARLY ROMAN PERIOD BURIALS OF PÚCHOV CULTURE: BURIED NATIVES OR OFFERED FOREIGNERS? ${ }^{1}$
}

\author{
K A R O L P I E T A
}

\begin{abstract}
The study presents and analyses materials from two hillforts located in North-Western Slovakia, where the Early Roman Age skeletal graves were discovered. At that time, Púchov culture hillforts disappeared abruptly. Significant changes in ethnical composition as well as in power structure led to the modification of settlement structure in the Western Carpathians. Numerous pieces of weaponry, inventories and hoards show that both hillforts analysed in this paper were destroyed in the first decades of the Current Era. Inventories of graves containing Noric-Pannonian attire can be attributed to the same period. So far, we do not know any cemeteries or graves of members of the culture dated back to the younger La Tène and Early Roman Periods. There are only sacrificial sites with dominating cremation rituals. Female burials found on the slopes below the fortifications in Bytča-Hrabové and in Mikušovce belong - together with the older finds from Púchov - to unique finds attributed to the culture. Judging by the position of the deceased and detected fatal injuries, we can assume that these burials reflect some previously unknown ritual practices. The question of whether the deceased were members of the local culture or rather new colonisers - presumably coming from the Noricum milieu - will be answered by prepared DNA and Isotope analyses.
\end{abstract}

Keywords: Western Carpathians, Northern Slovakia, Early Roman Period, Púchov culture, hillforts, decline horizon, skeletal graves, rituals, Noric-Pannonian costume.

\section{INTRODUCTION}

The development of burial customs in Western Carpathians in the early historic times has several specific features distinguishing it from surrounding lowland areas. Older native populations, traditionally living in this area at the end of Antiquity, cremated their dead and buried them in a relatively large graveyards, best known from central parts of the region inhabited by a very specific Orava group. In the western or south-western regions of the Middle Váh valley and Turiec with single cremation burials, the situation is different (Benediková 2017). Burial customs of the local settlers throughout the La Tène Period in the entire Western Carpathian region remain unknown. Human remains related to that period are known only as single bones found in settlement layers or at sacrificial sites that started to appear at the end of the older part of the Middle La Tène Period (Pieta 2010, 317-324; 2018). The discovery of skeletal graves at Late La Tène fortifications belonging to the Púchov culture in the Middle Váh valley was not only surprising but served also as an impulse to re-evaluate funeral habits as well as cultural and ethnic conditions at the turn of the La Tène and Roman Periods in this region. Research in Bytča-Hrabové and Mikušovce opened a new perspective on this issue and led to the revision of previous findings. The author is aware that there exists a terminological confusion and it is uncertain how should we refer to the deceased with traces of fatal injuries buried in standard attire but on an extraordinary site. Are these graves? Burials? Sacrifice?

\section{BYTČA-HRABOVÉ}

The Hlavina rock crest (575 m) is located nearby Hrabové village (Bytča-Hrabové, district Bytča), in the protected landscape area named Súlov Rocks (Fig. 1). The rocky hill is oriented north-south with a steep slope on the eastern side. In the west, it rises sharply but after reaching the height of the rock, the terrain passes into a milder slope. In the west, north and partially also in the east, we can notice rock terraces. The view of the site, covered by young beech forest, is dominated by two rock peaks crowning the north-south oriented rock crest passing toward the Brada hill (816 m; Fig. 2; 3: 1). From the saddle, south from the Hlboké village, there is an old road that could even be used as an original access route. The peak belongs to Strážov Mountains Protected Landscape Area and is covered with the fifth (highest) degree of the nature protection. The earth fortification is relatively hardly visible. In the south,

1 This paper was supported by the Project APVV-14-0842 'Central Europe between the Celtic Oppida and the Ancient Slavic Centres of Power' and by Project VEGA 2-0001/18 'Slovakia and the Middle Danube Region: development from the Early history to the Early Middle Ages'. 


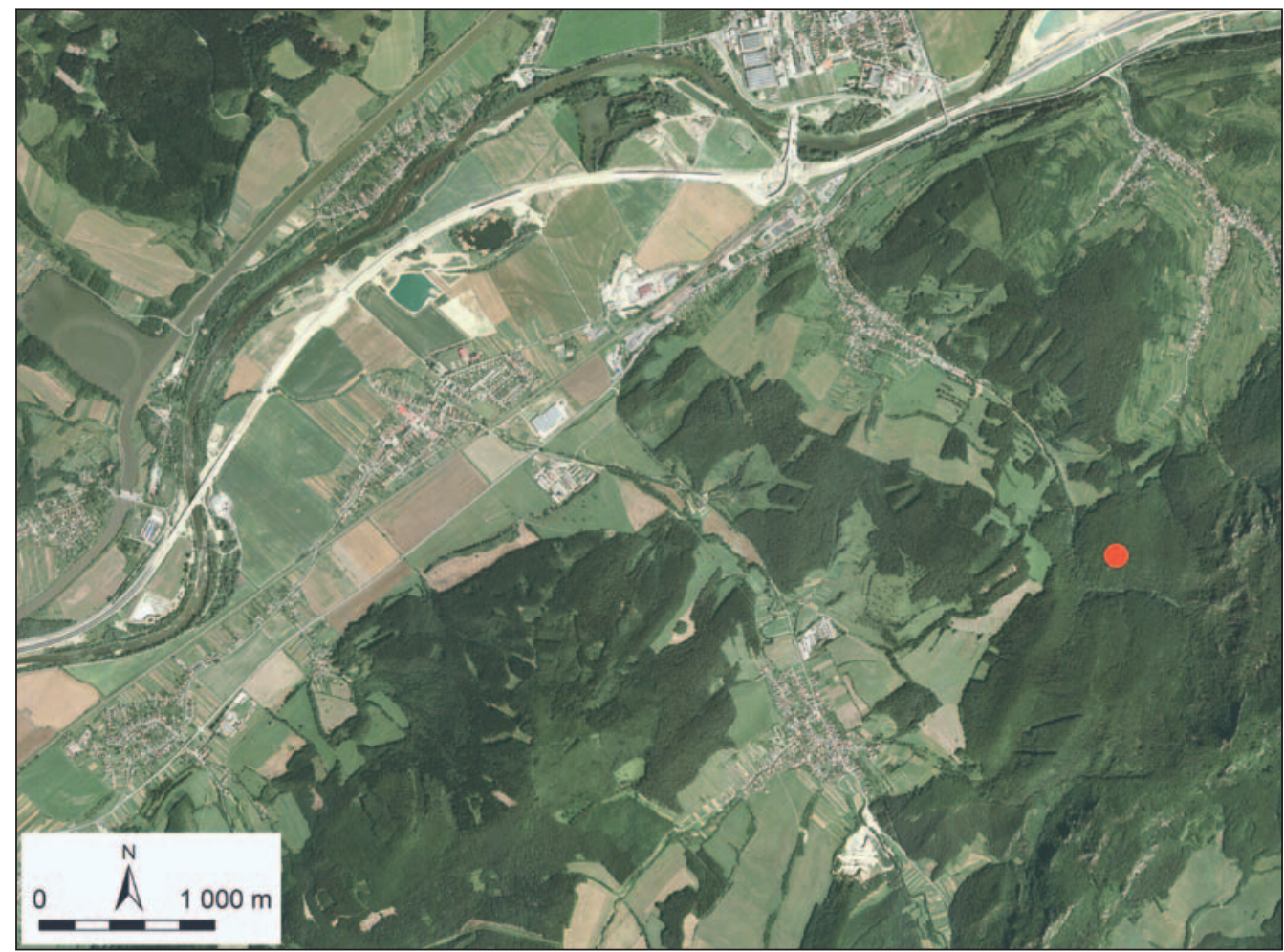

Fig. 1. Bytča-Hrabové. 1 - Benchmark location 575 m (Hlavina). Source: Ortofotomapa Eurosense, s. r. o. 2006.

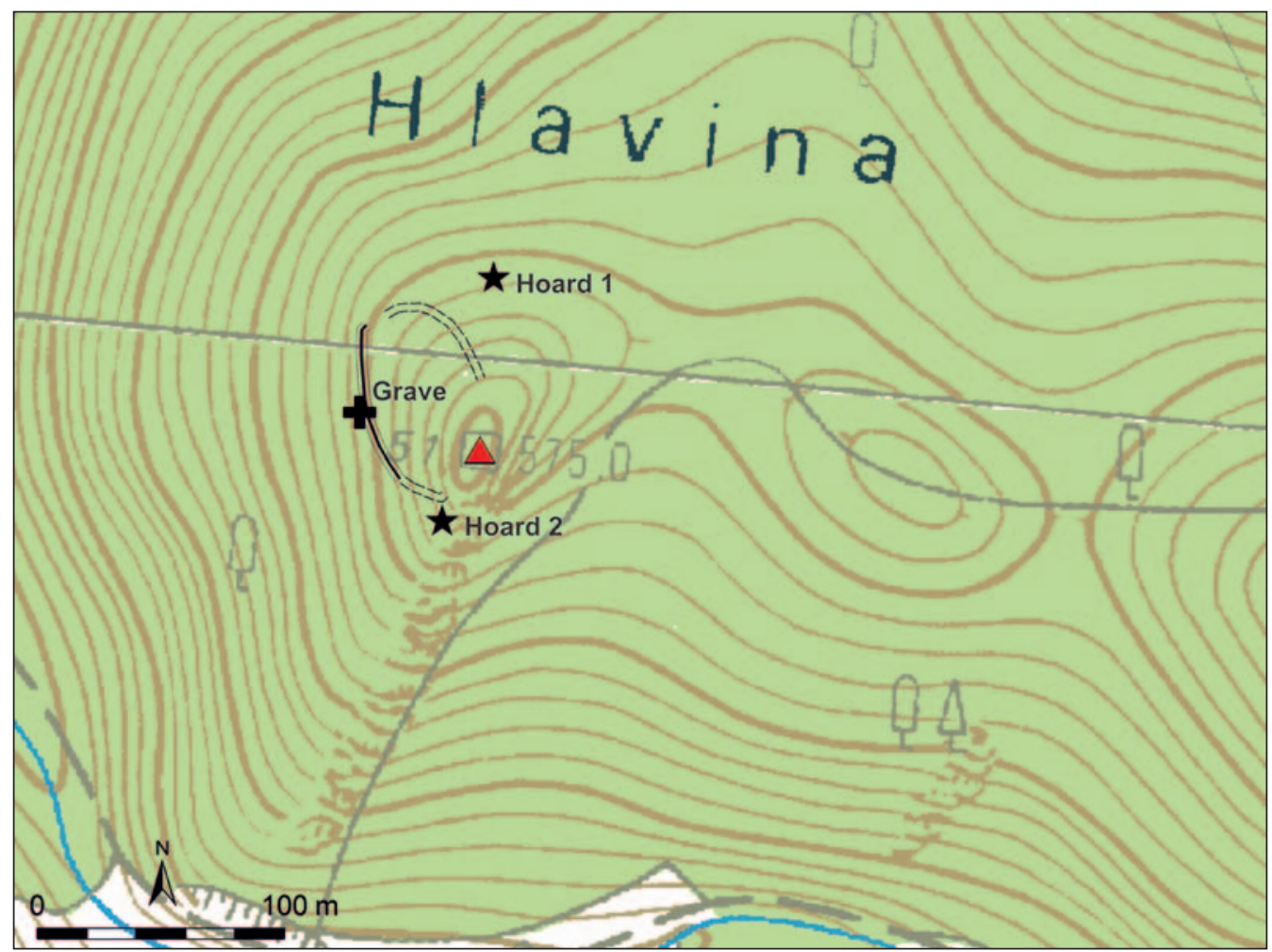

Fig. 2. Bytča-Hrabové. Plan of the Hlavina hillfort with marked locations of the double grave and hoards 1 and 2 . 

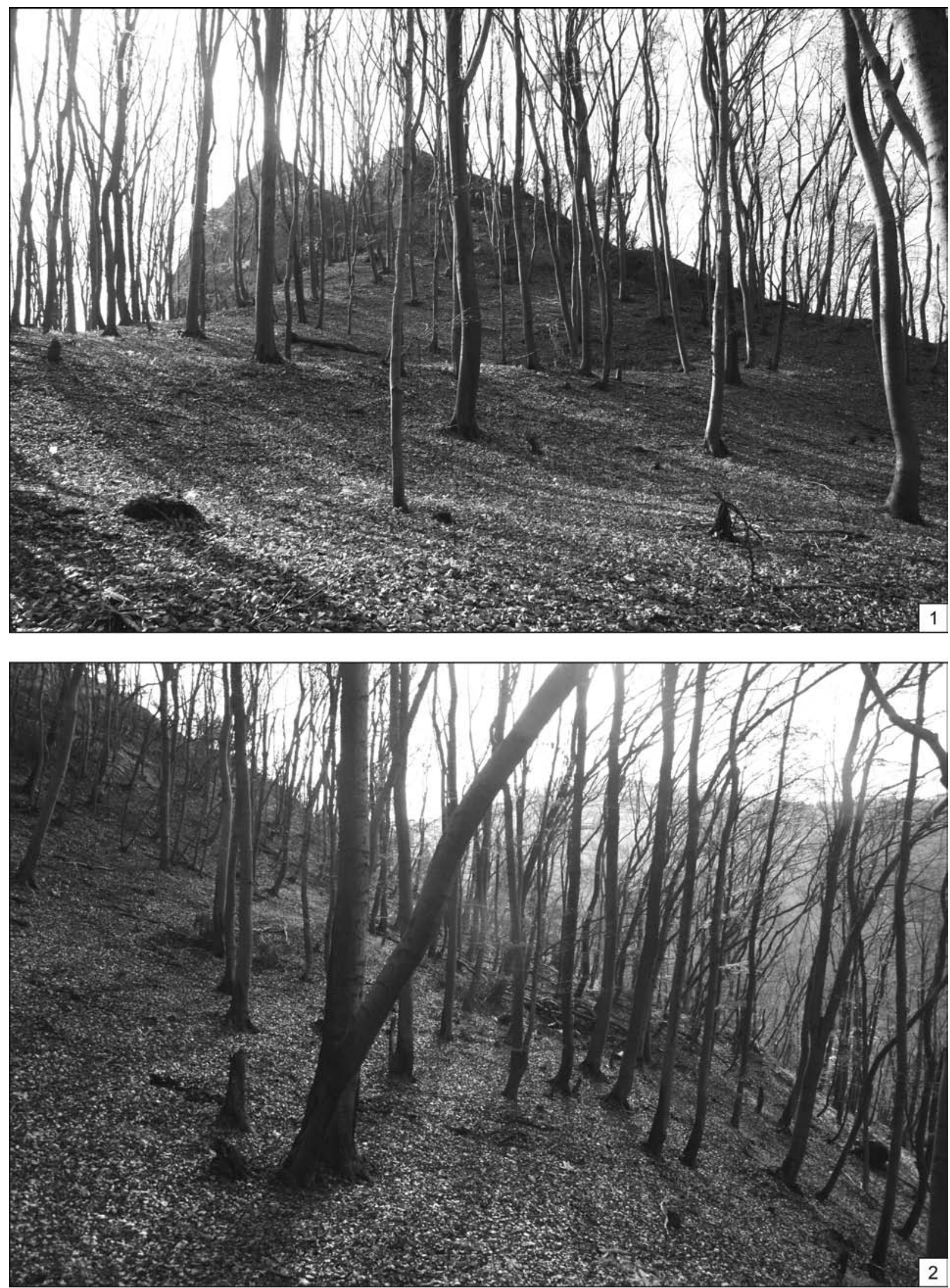

Fig. 3. Bytča-Hrabové. 1 - view of the Hlavina hillfort from the west, the rampart in the forehead; 2 - south-western part of the hillfort - view from the north-west, location of the grave in the background. 

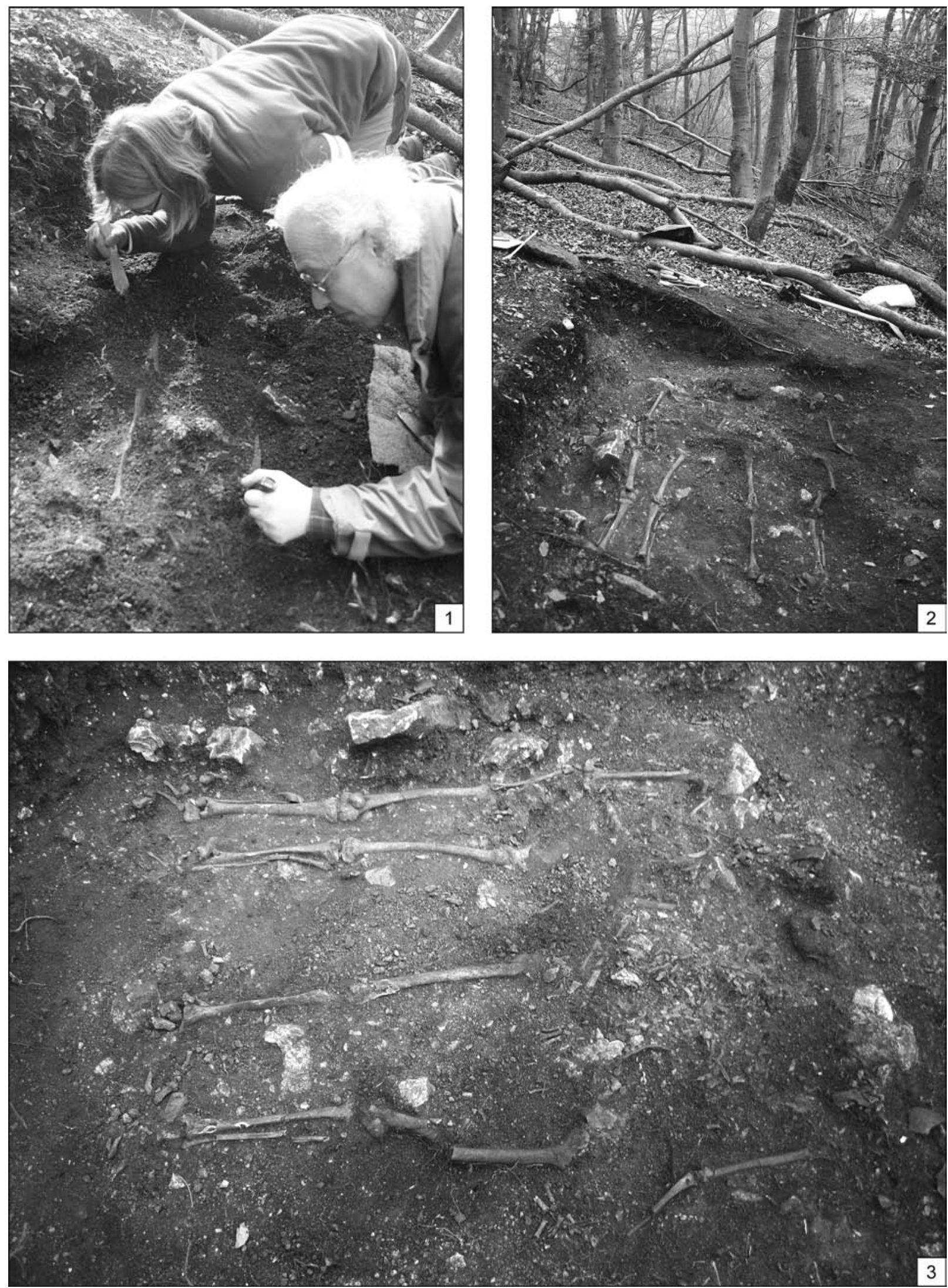

Fig. 4. Bytča-Hrabové. 1 - cleaning the grave; 2 - view of the double grave from the north; 3 - skeleton 1 (in the back) and skeleton 2 (in the forehead), view from the east. 
it joins with the rock massive and protects mainly the easily accessible west and north side of the hill with the assume entrance to the hillfort.

On October 22, 2008 the treasure hunters discovered human bones at the Hlavina hillfort and then reported the find directly to employees of the Institute of Archaeology SAS. The very next day the archaeologists started the survey. During the site inspection, in a spot where the soil was shifted below the rampart, they found human remains covered with dug soil. On an area of $200 \times 150 \mathrm{~cm}$, they revealed remains of two skeletons laid close to each other in the original layout. During threeday excavations together with the team (P. Ćerveň, Š. Hritz, M. Jakubčinová, L. Nezvalová, B. Šebesta, T. Vanglová), we managed to uncover and document both skeletons. Based on the fact that both skeletons were deposited at the same depth, similar aligned and also equipped with common artefacts (a vessel and a spindle whorl) we can conclude that it was a double grave. During the next research works in 2009 and 2010 in cooperation with authorities of Regional Monuments Board and Protected landscape area we found that the site was frequently damaged by amateur surveys. So far, only brief information

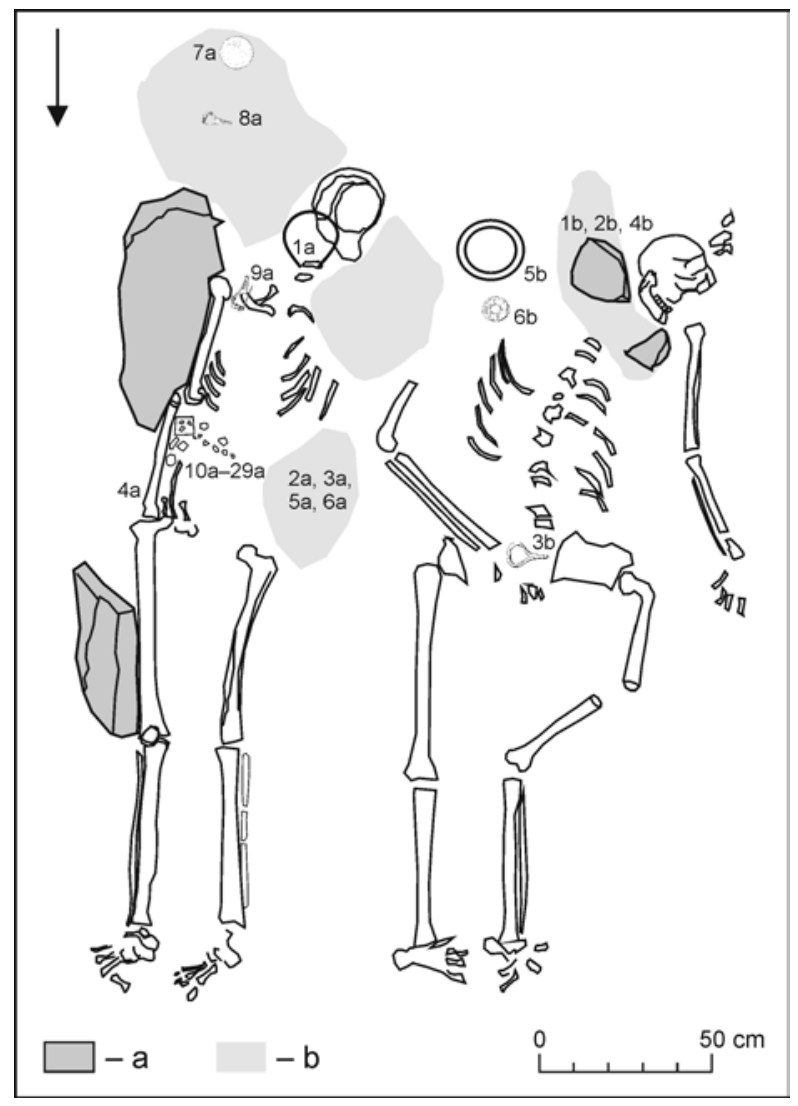

Fig. 5. Bytča-Hrabové. Skeletons 1 and 2. Legende: a stones; $\mathrm{b}$ - spots compromised before the survey. The numbering is consistent with item numbers on Fig. 6 and 7. was published about the find (Pieta 2010, 316, F40) as well as a short anthropological analysis of the skeletons (Jakab 2011).

Both skeletons, with their heads oriented to the south, were found in the western part of the fortification directly in a pile of soil from the rampart destruction (Fig. 2; 3: 2). Skeleton 1 was found on the eastern side, oriented towards the slope, $50 \mathrm{~cm}$ below the surface. The left side of skeleton 2 was placed just under the soil surface (Fig. 4: 2). Amateur explorers partly damaged the head, shoulders and left hand of skeleton 1 and neck as well as shoulders of skeleton 2 - that is the spots where signals from metal detectors are most likely (Fig. 5). Parts of the burial inventory (necklace, hooked belt clasp) as well as smaller, not fully bronze items (fragments of mirrors) were left on the spot. Traces of rust or patina allowed us to determine the original position of the artefacts in the grave. Collected bronze adornments were later returned (anonymously, through a third person) and the entire burial inventory was restored to its original condition.

The grave backfill contained loose dark brown soil with larger stones from the limestone bedrock, small pottery sherds and fine charcoal pieces. Long bones were relatively well-preserved. Flat bones, however, such as scapulae and pelvic bones, disintegrated. Skeleton 2, placed just below the soil surface, was in a worse condition.

\section{Skeleton 1}

The skeleton laid on its back in an outstretched position with legs placed parallel. The right arm was placed along the body, the left one was displaced by the amateur explores, similarly as the left shoulder and the head. The space behind the head was disturbed. The skull was also displaced, its parts, however, were in the correct layout. The head laid on its left side, closer to the left shoulder. On the eastern side, the body was lined with two large flat limestone stones that under the pressure of the soil on the slope felt on the right arm and the right femur. According to the anthropological analysis, the skeleton belonged to a 30-40-years old female. The skeleton was gracile and short $(152 \mathrm{~cm})$, with poorly developed muscles. The forehead, left temporal bone as well as the area of the coronal structure bear traces of strong perimortem blows made with a blunt instrument (Jakab 2011, 117).

\section{The inventory (Fig. 6)}

We have found components of equipment in the original position on the right side of the body 

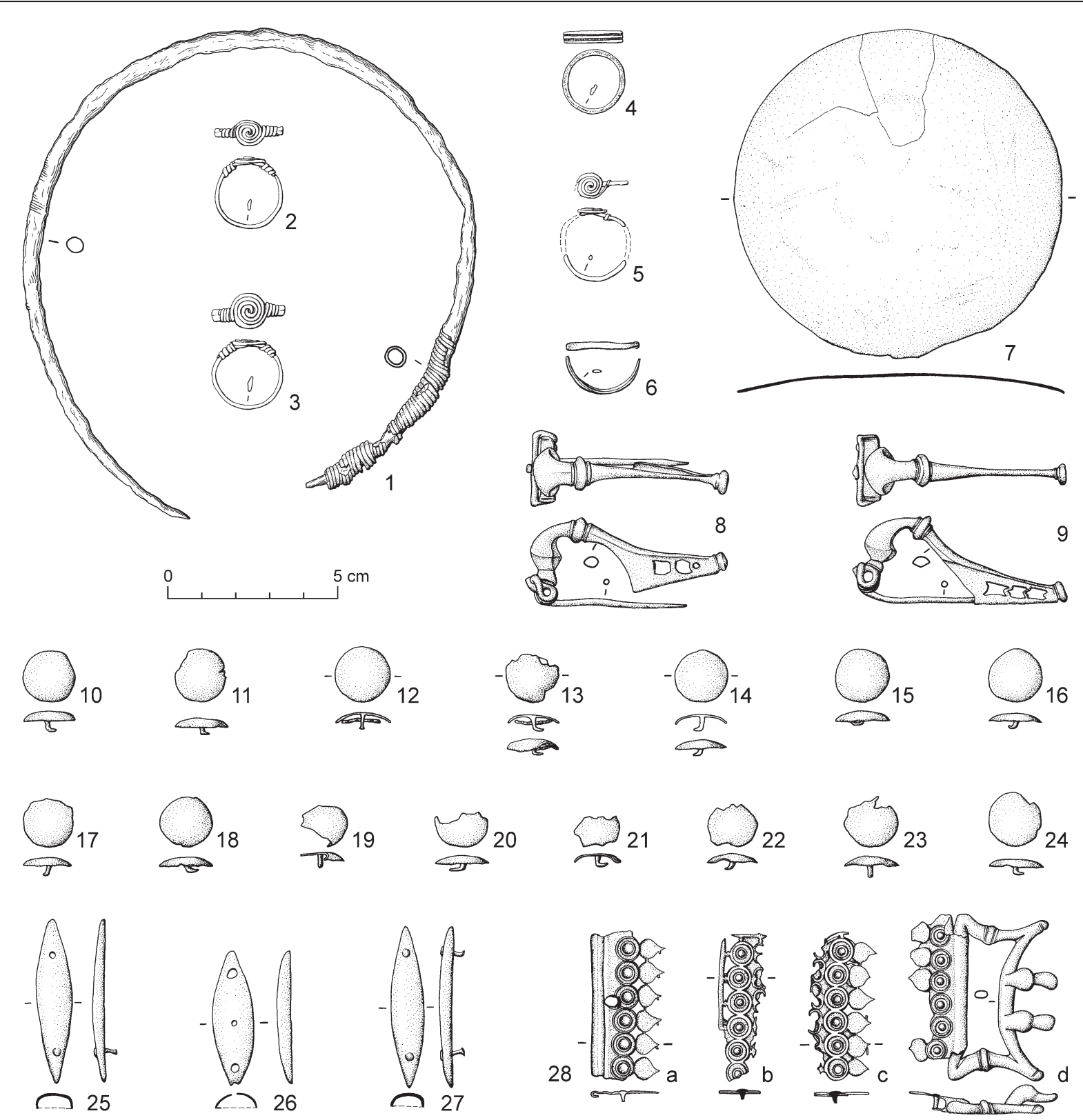
29

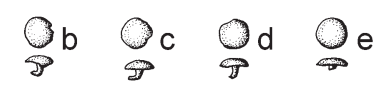

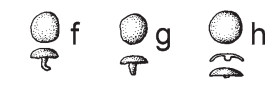

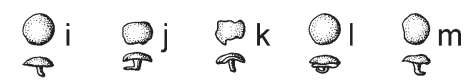

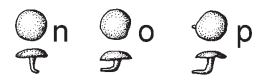

Fig. 6. Bytča-Hrabové. Inventory found by skeleton 1 (on Fig. 5 marked as 'a'). 1 - iron stick and a tin wire; 2-29-bronze.

protected by the stones lining the grave. The front part of the belt decorated with fittings and rivets was partly damaged, while the right and the back parts found at greater depth were well-preserved. The clasp was found on the right side of the body, just over the pelvic bone. The belt was rimed with a row of rivets. The rivets found below the clasp most likely decorated a strap passing through the clasp.

The following artefacts were found in the original position:
- A bronze fibula A 67 was placed on the right collarbone with its foot oriented upward. It has a straight foot with a small flat knot and a catchplate with two rectangular and one round opening, $63 \mathrm{~mm}$ long (Fig. 5: 9a; 6: 8).

- A fragment of a bronze ring on the right-hand phalanx (Fig. 5: 4a; 6: 6).

- A two-part bronze belt clasp of the Garbsch G2c type with a double hook and double-sided, with rings decorated and with rivets linked sup- 
porting plaques of the Garbsch B7 type (Fig.5: 10a-29a; 6: 28d).

- Three bronze boat-shaped fittings with two rivets and their other fragments (Fig. 5: 10a-29a; 6: 25-27).

- 15 bronze rivets, $15-16 \mathrm{~mm}$ in diameter (Fig. 5: 10a-29a; 6: 10-24).

- 16 bronze rivets, $6 \mathrm{~mm}$ in diameter (Fig. 5: 10a-29a; 6: 29a-p).

Dislocated but found on the site artefacts from around the head, the left shoulder and the space behind the head:

- An iron oval open neck ring made of an iron stick entwisted at the ends with a tin wire containing also lead (4,13\%) and copper (1,59\%). The wire decoration preserved only partially and in some spots, there are visible only imprints of the wire on the iron. Dimensions: $140 \times 130 \mathrm{~mm}$, diameter 5 mm (Fig. 5: 1a; 6: 1).

- A bronze fibula A 67 with a straight foot with a small flat knot at the end and a catch plate with three rectangular openings, $65 \mathrm{~mm}$ long (Fig. 5: 8a; 6:9).

- A white bronze mirror, round and convex, diameter 95 mm (Fig. 5: 7a; 6: 7).

- Fragments of a bronze openwork belt plaque with rivets (Fig. 6: 28a-c).

Dislocated items, most likely from the area around the missing left arm:

- A small bronze ring (Fig. 5: 6a; 6: 4).

- One damaged and two complete bronze finger rings made of wire with one end forming a roselike coil and the other wrapped around the ring (Fig. 5: 2a, 3a, 5a; 6: 2, 3, 5).

Traces of organic materials on bronze parts of the belt were analysed (textile analysis by T. Štolcová 2011). There were traces of some organic material on the bottom parts of numerous rivets. Probably the material was leather, however, we were unable to determine its type precisely. Bronze patina covering one of the rivets contained a fragment of linen/hempen textile made in linen weave.

\section{Skeleton 2}

The skeleton laid on its back in the outstretched position. Legs - from the knees downwards were placed parallel. The left hip together with the femur was slightly displaced down the slope - probably due to erosion or pressure exerted by roots. The femur was broken, but the injury was original and was not related to the amateur exploration of the site. The upper part of the body was slightly arched towards the slope. The skull - damaged by the mass of soil - was placed on its left side in the original position. Behind the head, there we a larger flat stone. The space behind the head and around both shoulder was distorted. Traced of patina indicated spots where taken and then returned artefacts. Fragments of the right arm and of the right shoulder were missing. The space behind the head there was a mirror 2 which, however, preserved only partially. The pelvis bones were crushed but intact in the original position. The right arm was slightly bent and the hand with preserved fingers was placed on the womb, where also a hooked clasp was found. Between the heads, there was a small broken vessel and closer to the skeleton 2 chest, we have found a spindle whorl.

Skeleton 2 belonged to a $20-30$-years old female. The skeleton was gracile and about $155 \mathrm{~cm}$ tall, with poorly developed muscles.

Numerous skull bones, the mandible and primarily the forehead bone bear traces of perimortem injuries - undoubtedly strikes made with a sharp instrument, probably an axe (Jakab 2011, $117,118)$.

\section{The inventory (Fig. 7)}

The following artefacts were found in the original position close to skeleton 2:

- A clay bowl with a rim wrapped to the inside, rounded belly in the upper part and slightly spaced bottom. Its polished surface was black. It was $69 \mathrm{~mm}$ high. The bottom diameter was $60 \mathrm{~mm}$ while the rim diameter was $97 \mathrm{~mm}$ (Fig. 5: 5b; 7: 5).

- The spindle whorl made of a graphite pottery sherd and decorated with vertical grooves. Diameter $37 \mathrm{~mm}$ (Fig. 5: 6b; 7: 6).

- An iron hooked clasp with an oval frame and rectangular in cross-section, $53 \mathrm{~mm}$ long and $33 \mathrm{~mm}$ wide (Fig. 5: 3b; 7: 3).

Dislocated artefacts from the distorted space behind the head and around both shoulders:

- A bronze fibula of the A 67 type with a straight foot and a flat knot and a rectangular openwork bow, $74 \mathrm{~mm}$ long (Fig. 5: 1b; 7: 1).

- A bronze fibula of the A 67 type, with a straight foot, profiled knot and a rectangular openwork catch plate, $78 \mathrm{~mm}$ long (Fig. 5: 2b; 7: 2)

- A white bronze mirror, round and convex, partially preserved. Diameter $71 \mathrm{~mm}$ (Fig. 5: 4b; 7: 4). 


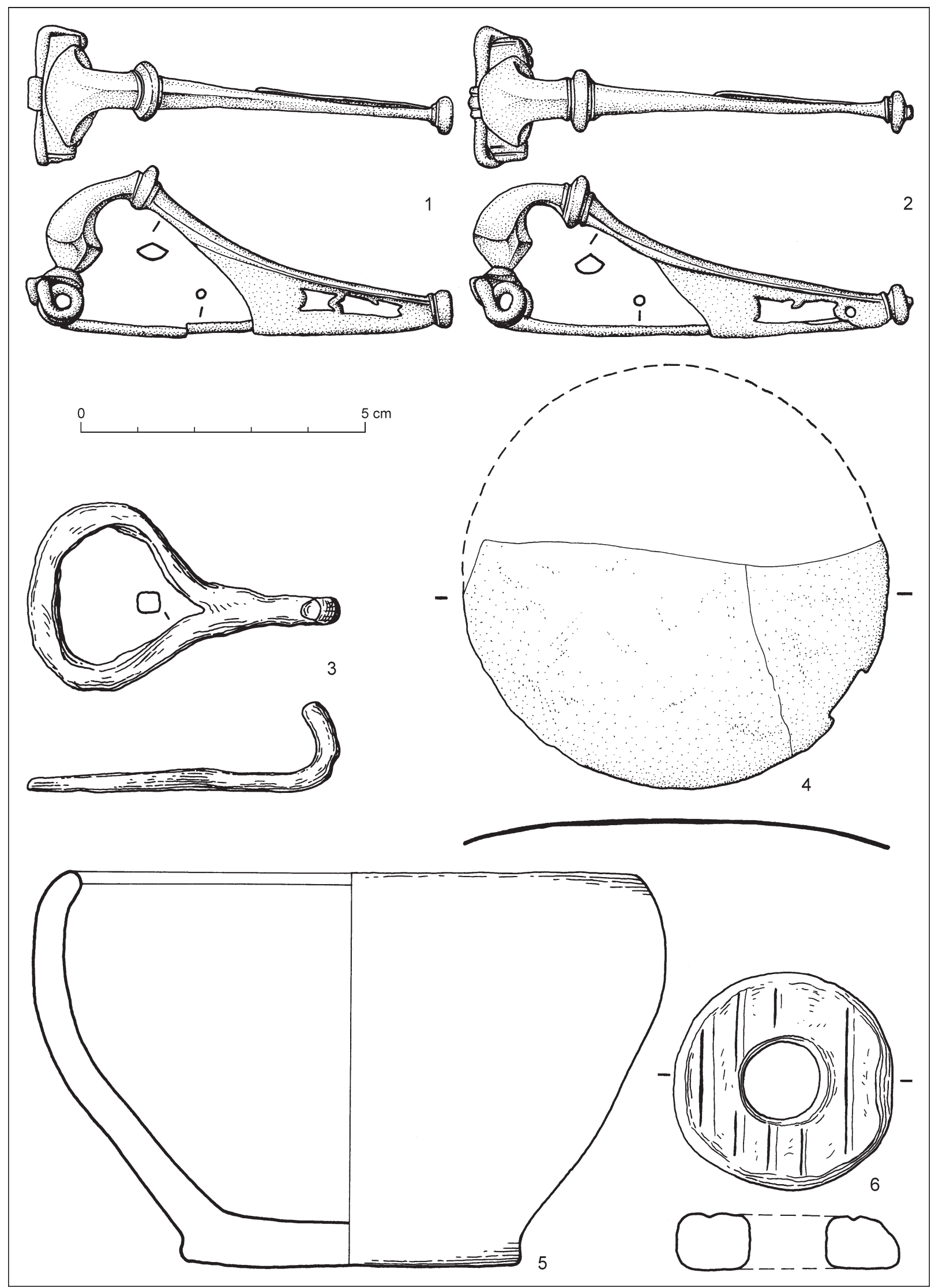

Fig. 7. Bytča-Hrabové. 1-4 - inventory found by skeleton 2 (on Fig. 5 marked as ' b'); 5, 6- Artefacts deposited between the skeletons 1 and 2. 1, 2, 4- bronze; 3 -iron; 5, 6 - pottery. 


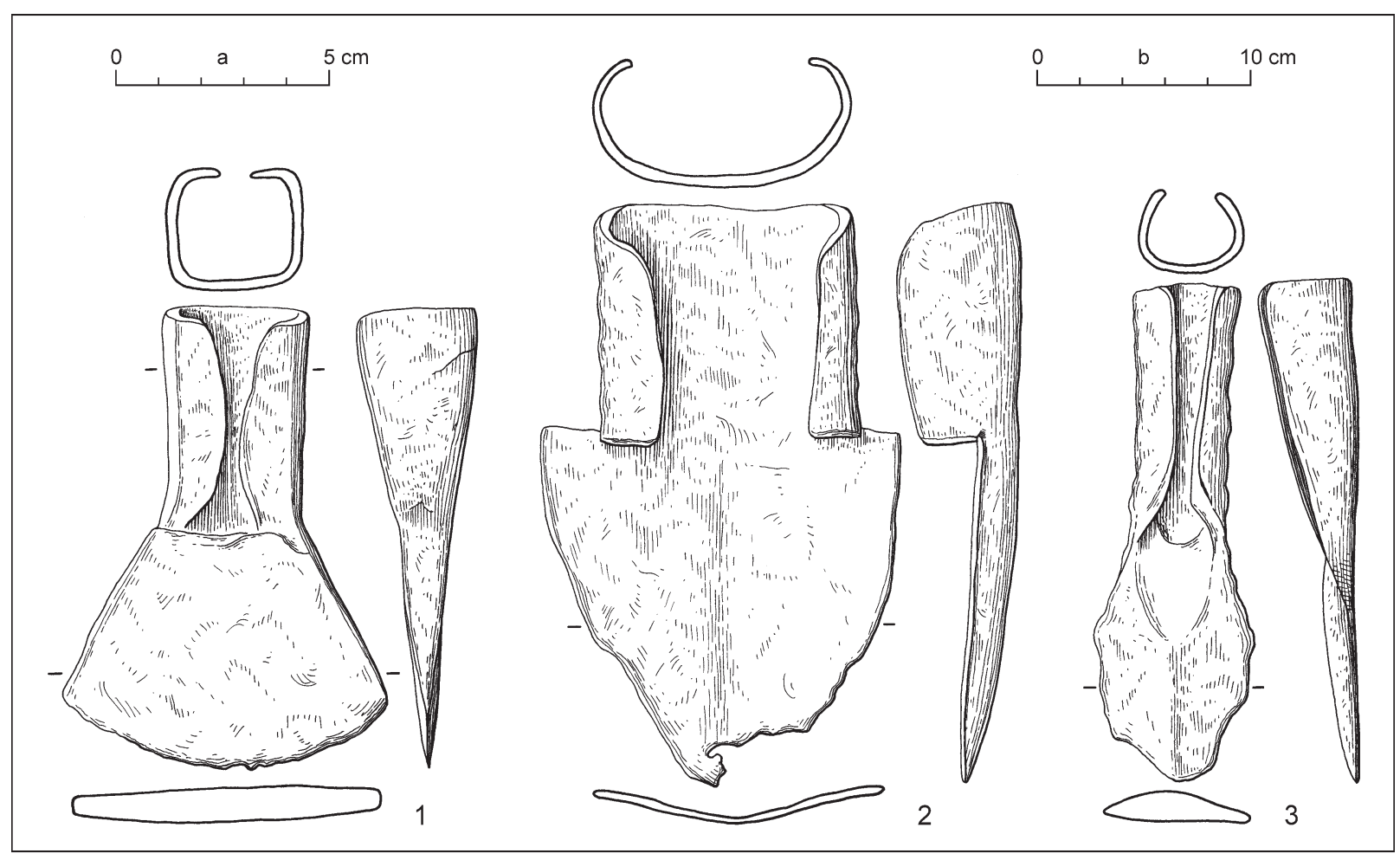

Fig. 8. Bytča-Hrabové. Hoard 1. All items made of iron. Scale: $a-1 ; b-2,3$.

\section{Other finds from the hillfort Bytča-Hrabové, Hlavina}

During 2008-2010 activities we performed measurements and surveys which resulted in the discovery of numerous metal artefacts, iron slag, a fragment of a rotary quern, animal bones and pottery. In numerous places, we have also found pebbles. The hillfort, as well as the slopes surrounding it, abounded in arrowheads. During the research, we documented the location and content of two small hoards uncovered by the amateur explorers.

\section{Hoard 1}

- Hoard was found in the northern part of the site, $30 \mathrm{~cm}$ below the surface. It contained two iron ploughs and three axes (Pieta 2010, 338). Both ploughshares and one axe were handed over to the Institute of Archaeology SAS.

- Axe with a narrow, fan-like blade and an open socket rectangular in the intersection. The blade was $216 \mathrm{~mm}$ long and $154 \mathrm{~mm}$ wide (Fig. 8: 1).

- Ploughshare with a wide, slightly deflected, triangle leaf-like body with traces of damages on the blade. The fastening part with long, side lobes was oval. The ploughshare is $272 \mathrm{~mm}$ long and $170 \mathrm{~mm}$ wide (Fig. 8: 2).
- Ploughshare with a short leaf-like body and a clearly visible centreline. It shows traces of long-term use. The long fastening loop conically narrows along the longer axis. It was $236 \mathrm{~mm}$ long (Fig. 8: 3).

\section{Hoard 2}

Hoard had been found on the steep southern slope by an anonymous explorer and then returned to the Trenčín Museum (Fig. 9). The collection included a buckle, two belt fittings, a strap-end, a bronze and an iron stick (a strike-a-light and an awl) and two drinking horn fittings. On the site, the author of the paper detected an amateur trench about $100 \times 100 \mathrm{~cm}$, were during the further investigation a suspending bronze ring (Fig. 9: 6) undoubtedly belonging to the hoard has been found. Traces of bronze patina found in several places of the trench confirmed that this was the original location of the hoard. However, due to the circumstances of the discovery, it remains uncertain whether the recovered collection is complete. Based on the ornaments (circular decorative punching, plastic, structured ribs) on four found items, all the artefacts undoubtedly formed one set of metal belt decorations. The current state of the artefacts suggests that the set contained a buckle, a loop, a strap-end and two suspending 


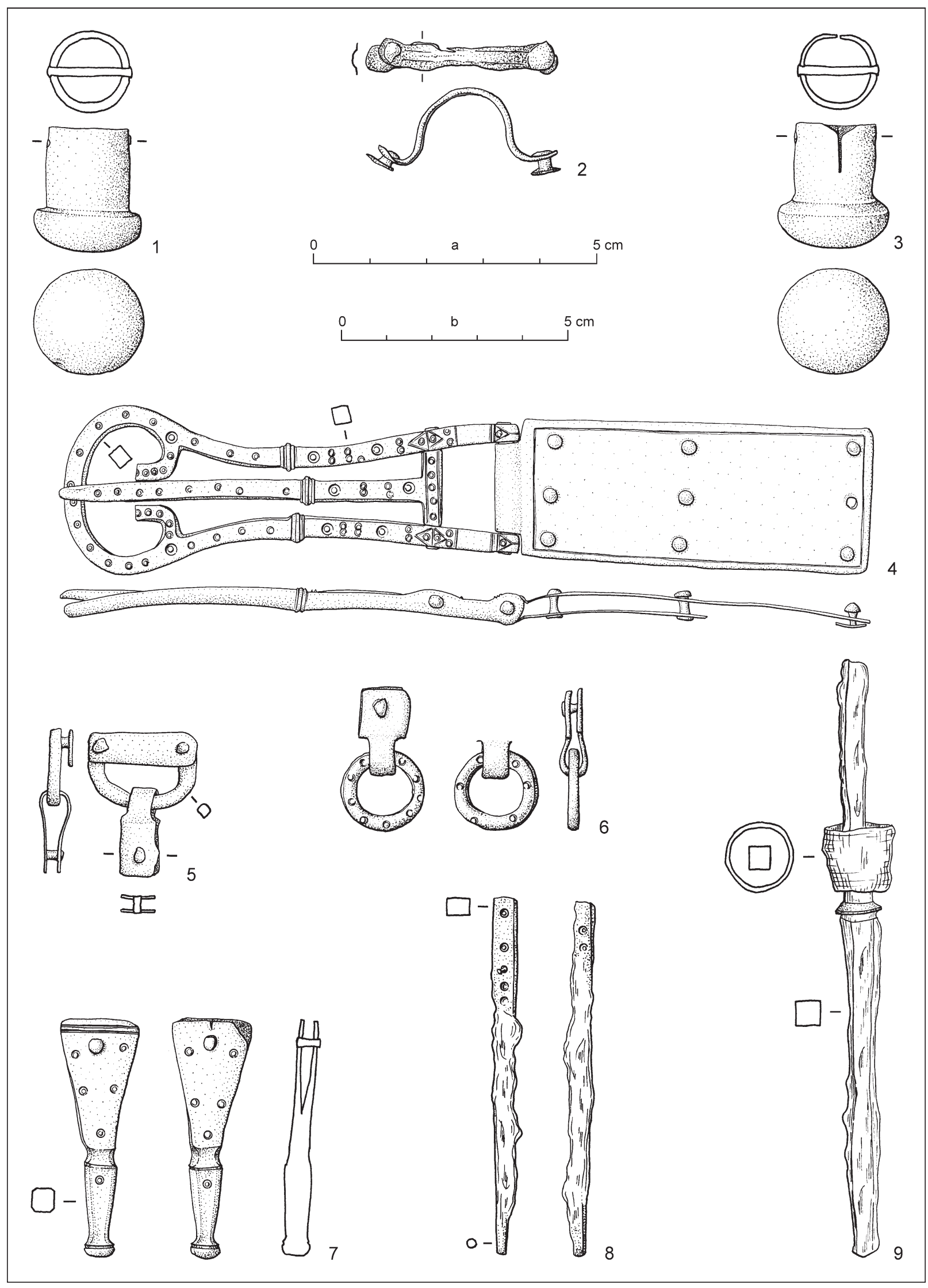

Fig. 9. Bytča-Hrabové. Hoard 2 - belt elements. $1-8$ - bronze; 9 - iron and bronze (the ring). Scale: a - 1-3, 5-9; b-4. 
rings. The strike-a-light and the awl were fastened on the belt and the traces of rust indicate that the two hung side by side. The set contained also two drinking horns.

- The eight-shaped bronze buckle (type U) was decorated with engraved and hammered plastic ornament. A long, characteristically bent frame with an omega-like fitting as well as a pin with a hinge axis were rectangular in the intersection. The plate was fastened to a leather belt with three clusters of three rivets. It was $178 \mathrm{~mm}$ long (Fig. 9: 4).

- The strap-end was circular in the intersection with a round tip and a triangular fastening plaque with one rivet. Its surface was decorated with fine round stamps. $45 \mathrm{~mm}$ long (Fig. 9: 7).

- The bronze suspending ring decorated with round stamps and a rectangular fastening plaque. The ring is $17 \mathrm{~mm}$ in diameter (Fig. 9: 6).

- The bronze belt loop with fastening rivets at both tips. Slightly deformed. $34 \mathrm{~mm}$ long (Fig. 9: 2).

- The bronze fastener with a fastening plaque, two rivets and a suspending ring with a rivet. $27 \mathrm{~mm}$ long (Fig. 9: 5).

- The bronze pointed stick (an awl? a toothpick?). It rectangular base was decorated with round stamps. There was also a cross rivet used to fasten a handle of some organic material. The surface was covered with iron rust. $66 \mathrm{~mm}$ long (Fig. 9: 8).

- A needle-like strike-a-light, rectangular in the intersection, with a bronze ring and an iron clamp for fastening of organic handle. $110 \mathrm{~mm}$ long (Fig. 9: 9).

- A drinking horn fitting in cylindrical form with a semi-circular tip and a cross rivet. $23 \mathrm{~mm}$ long (Fig. 9: 1).

- A drinking horn fitting in an open cylindrical form with a semi-circular tip and a cross fastening rivet. $23 \mathrm{~mm}$ long (Fig. 9: 3).

Close to the site, about $1 \mathrm{~m}$ below the trench, we have found 8 granite pebbles and 7 arrowheads. All these items - forming another, intact deposit were found just below the surface on an area of $30 \times 40 \mathrm{~cm}$. Elsewhere, we have found also two iron bracelets (Fig. 10: 13, 16).

On the hillfort, we have detected several traces of iron processing: fragments of slag and semifinished products like partly processed sticks, plates and forging semi-products (Fig. 11: 1, 3, 16). Two fragments of iron plates from which arrowheads were cut out belong to the most exceptional finds (Fig. 15).

\section{Analysis of single artefacts}

\section{Ornaments and parts of dress}

The site inventory includes also complete as well as fragments of iron and bronze brooches that undoubtedly cover the entire period of the site existence (Fig. 10: 1-9).

The MLT (Middle La Tène) scheme plain brooches (Fig. 10: 1, 7) were made most often of iron wire. Usually, they are arched, sometimes asymmetric, with internal or external chords. Dating of the artefacts cannot be narrowly defined. This final effect of the long-time evolution of wire brooches with a foot fixed to the bow was invented at the end of the Middle La Tène Period (LTC2). However, based on numerous contexts within the Púchov culture, we can assume that such items were used also at the beginning of the Roman Period. Furthermore, it seems likely that such artefacts were more frequent in the western peripheries of the culture than in its centre (Pieta 2014, 134, 135). In other areas, such simple wire brooches were used until the end of the $1^{\text {st }}$ c. AD (Keller 1984, 22; Riha 1994; Gruppe 1, Typ 4).

Arched brooches with a belt-like bow (Fig. 10:3, 5) were very popular in the Púchov culture, mainly in iron variants. Usually, such fibulas had a four-fold coil with an internal chord and plain or frame-like fastener (Pieta 2014, 135). Such items are found in areas settled by Celts or Dacians in the Middle Danube Basin and in the Upper Tisa Basin and clearly belong to the Late La Tène D1 stage.

Bent bow brooch in a simple iron variant with a plain bow and a knot only indicated with a small knot just over the curvature (Fig. 10: 4). It belongs to standard Púchov inventories attributed to the LTD2 stage. Such artefacts were made of wire semi-product and imitated more complex bronze specimens with a plastic knot and gradually arched fastener attributed to type Almgren 18 (Demetz 1999, 116-120).

Idria type brooches dated back to the Late La Tène D2 are represented here by one bronze specimen (Fig. 10: 2). These were most popular in Noricum and in the Upper Drava and Sava Basins. From the Púchov culture, we know single, bronze specimens closely resembling the originals (KošecaNozdrovice) as well as iron imitations of those (Folkušová-Necpaly: Pieta 2014, 135, 136).

A brooch with eyelets Almgren 45 with side insets by the eyelets (Fig. 10: 6) belongs to the oldest forms of this type of fibulae that received considerable attention in the extant literature (Droberjar 1999, 61-66; Glüsing 1968, 56; Kunow 1998, 100). It belongs to the oldest phase of the Roman Period 


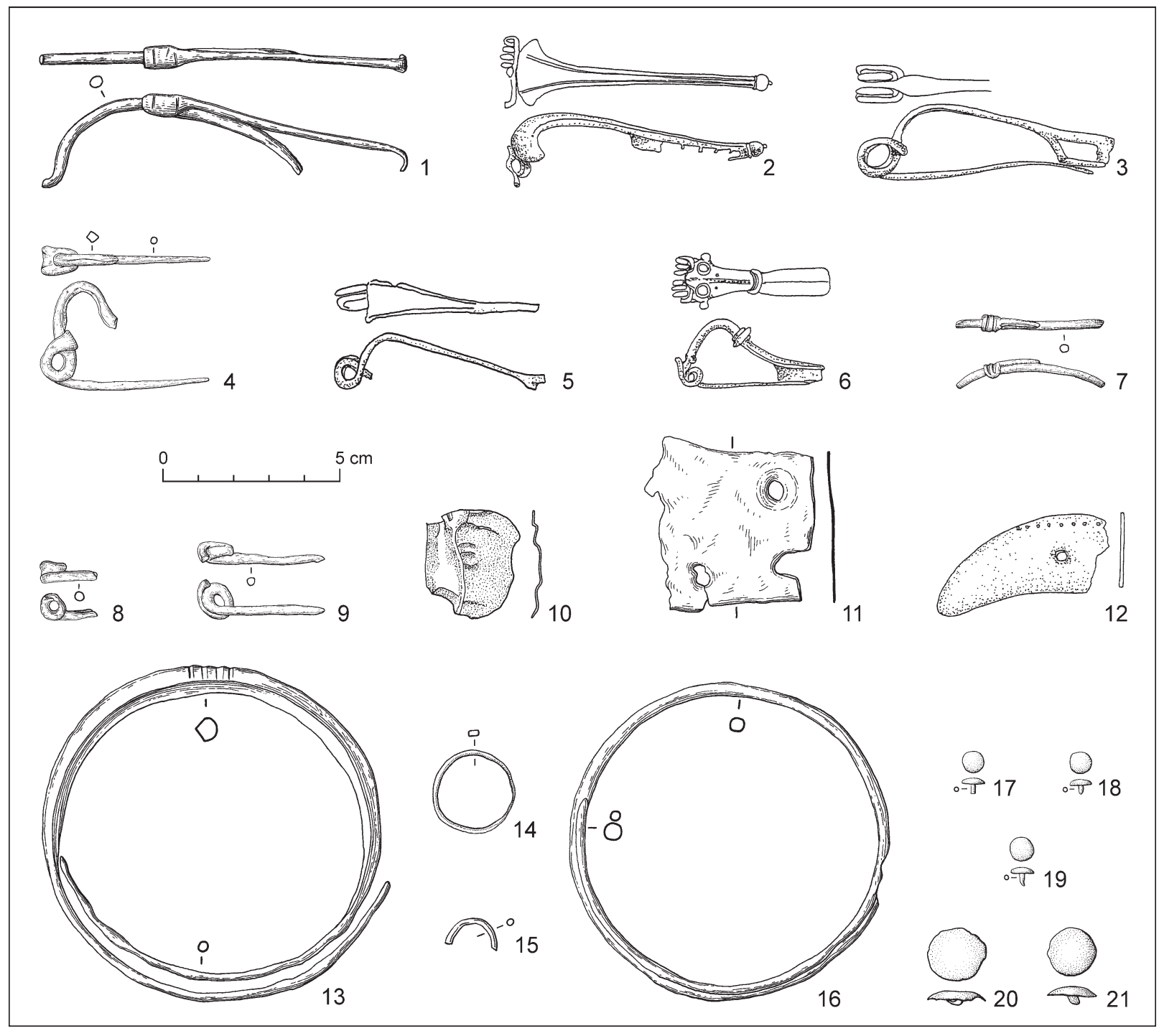

Fig. 10. Bytča-Hrabové. Fibulae and decorative artefacts from the Hlavina hillfort. 1, 4, 5, 7-9, 11, 13, 16 - iron; 2, 3, 6, 10, $12,14,15,17-21$ - bronze.

(B1a). This type of brooches is relatively uncommon at North Slovak sites (Mošovce) and certainly, its origins should be sought abroad.

Bracelets are represented by two iron open rings with narrowed tips overlapping half of the bracelet perimeter (Fig. 10: 13, 16). One of the artefacts is decorated with transverse notches in the middle. Both bracelets were found together as a small hoard. The internal diameter of the decorated and the plain bracelet is $78 \mathrm{~mm}$ and $81 \mathrm{~mm}$, respectively. Bracelets with a double coil occurred parallel with other types of circular jewellery throughout the La Tène Period, possibly as a continuation of the older, technically simpler tradition (Bujna 2005, 108-110). Structurally similar ornaments were found also in Germanic grave inventories attributed to the older Roman Period (Kolník 1980, pl. XVII: 26c).
Belt from the above mentioned mass find 2 belongs to exceptional finds in the mountainous Slovak areas. In order to date it properly, it is necessary to focus on the eight-shaped buckle (type U; Fig. 9: 4). The buckle has analogies among well-dated grave assemblages at numerous Barbaricum sites (Blankenfeldt 2015; Kolník 1977). According to the typology proposed by R. Madyda-Legutko (1987), we can attribute the specimen from Bytča-Hrabové to type 3 , although it has some features characteristic to type 18. U-type buckles are related to the beginning of the Roman Period (B1a), however, in the mountainous parts of Slovakia, outside the areas settled by the Quadi, such finds are rare (Nitrianska Blatnica - Pieta 2017, fig. 4: 2).

Mass find 2 can hardly be referred to as a hoard, because - in fact - it is a votive composition of 


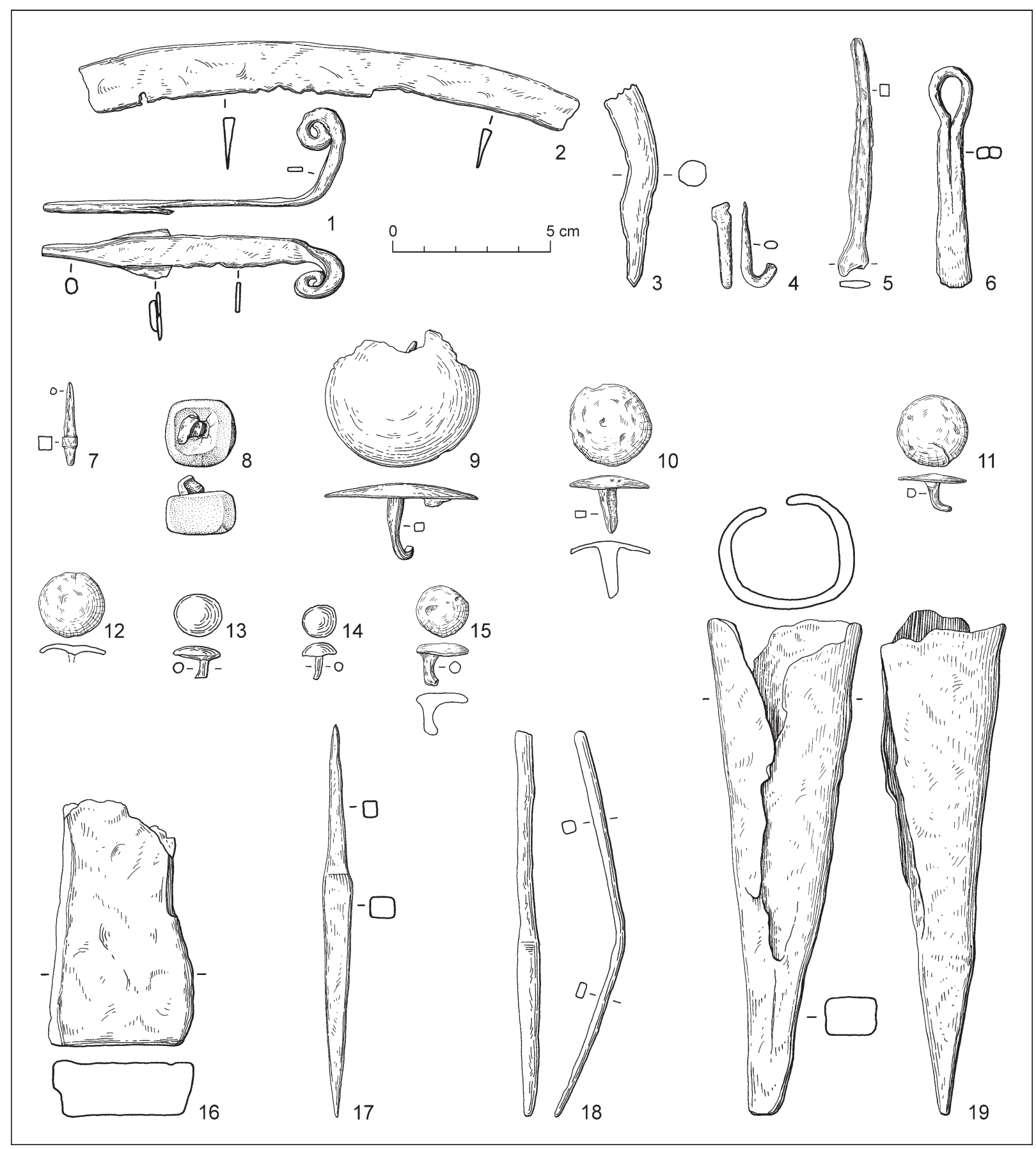

Fig. 11. Bytča-Hrabové. Finds from the Hlavina hillfort. 1-7, 9-19-iron; 8 - lead and iron.

a single item, the belt. We should mention here that depositing or ritual offering of the belt, a socially praised attribute of its owner, was repeatedly documented as a single find - either a deposit or an element of offerings at cult sites (Čambal/Budaj 2009; Pieta 2018).

The presence of drinking horns as components of the male belt set is confirmed by the finds of fittings (fig. 9: 1, 3). These specific vessels were very popular both in the Celtic and Germanic world
(Andrzejowski 1991; 2002; Bockius/Euczkiewicz 2004, 102-110; Droberjar 1999, 54, 55; Redlich 1977; Zeman 2017, 142-144). In the Púchov milieu such fittings as well as suspending chains - as confirmed by single finds from hillforts - were used already during the La Tène phase (Kolačno - Pieta 2010, fig. 124: 3). An interesting find in this context is a bull-head fitting found at the Rochovica hillfort (Žilina-Vranie - Pieta 2010, fig. 130: 9). The item represents type $E$ with a relatively long chronology, including the begin- 


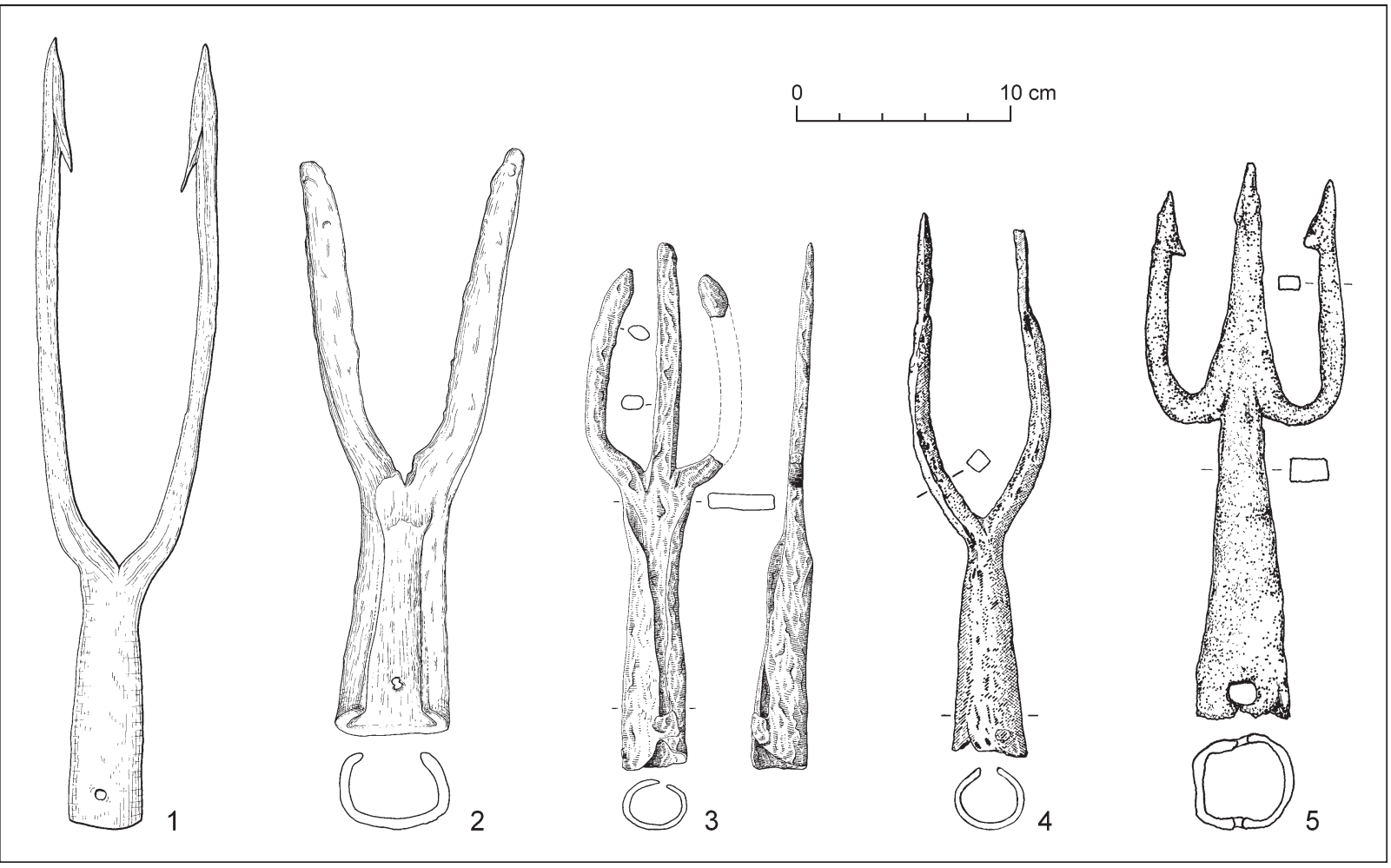

Fig. 12. Two- and three-prong pitchforks. 1 - Mošovce; 2 - Bytča-Hrabové; 3 - Liptovská Mara I; 4 - Weismein, grave 79; 5 - Skalka nad Váhom.

ning of the Roman Period, and popular mainly in Scandinavia (Andrzejowski 1991, 36-38). Only slightly younger, a semi-globular horn fitting is known from the site Liptovská Mara III (Pieta 1982, pl. XVI: 4; Švihurová 2017, 137).

\section{Tools}

At the Hlavina hill fort, a fragment of a sickle blade (Fig. 11: 2) and three ploughshares (Fig. 8: 2, 3; 11: 19) have been found. Based on the mass finds, ploughs with wide ploughshares were used in parallel with narrow, arrow-shaped types and most likely had different application - for various types of soil and crops. Ploughs with leaf-like ploughshare started to appear at the end of the La Tène Period and in the early Roman Period as a continuation of narrow arrow-shaped types and in the Púchov culture were relatively comon (Pieta 2010, 231, 236). Both specimens from hoard 1 match this developmental scheme.

A pitchfork-like tool (hooked bident). During the surface survey, we have found an item with an open sleeve and two massive, triangular in intersection prongs pointing slightly to the sides (Fig. 12: 2). Two- and three-prong pitchforks with a sleeve are known from inventories from the Middle La Tène Period (Urban 2006) through the Migration Period up to the Early Middle Ages (Husár 2014, 70, 71; Mazuch 2003, 361) and even in the Modern Era. According to the iconographic sources and shapes of the prongs, we can assume that these were used as fishing or hunting tools. The analysis of the Carolingian grave no. 79 in Weismain - where the deceased was equipped with two-prong pitchfork resembling the one from Hlavina - we can assume that the artefact had a relatively short, $40 \mathrm{~cm}$ long, handle similar to meat forks (Fig. 12: 4; Pöllath 2002, 171, 172). Pitchforks (hooked bidents) with three prongs are also known from La Tène hoards (Gründberg - Urban 2006, 85, fig. 6). Unfortunately, from the Slovak (La Tène) sites we knew only single finds that cannot be dated more precisely. The site list includes Mošovce (Fig. 12: 1), Bytča-Hrabové (Fig. 12: 2), Liptovská Mara I (Fig. 12: 3), Skalská Nová Ves-Skalka (Fig. 12: 5), Čachtice, Nimnica, Rakša.

\section{Weaponry}

Pole weapons are represented by two spear points. Similarly, like many other Púchov hillforts, Hlavina abounds in 'cartridges of long-distance weapons' - hand- or sling-thrown pebbles and arrowheads (Fig. 13; 14). The Institute of Archaeology SAS inventory contains 107 complete iron arrowheads or their fragments and further eight 

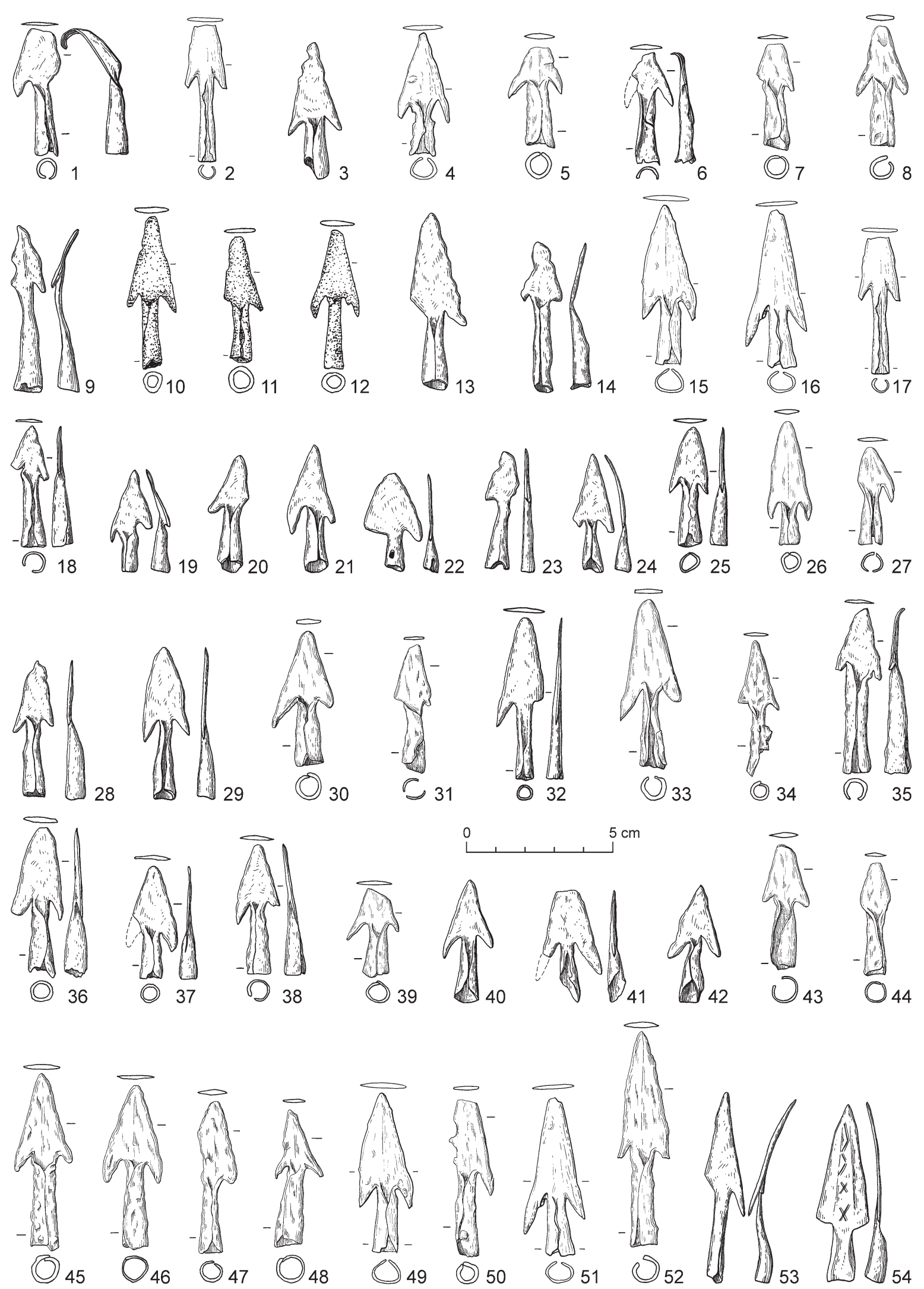

Fig. 13. Bytča-Hrabové. Arrowheads from the hillfort and the area around the ramparts. Iron. 

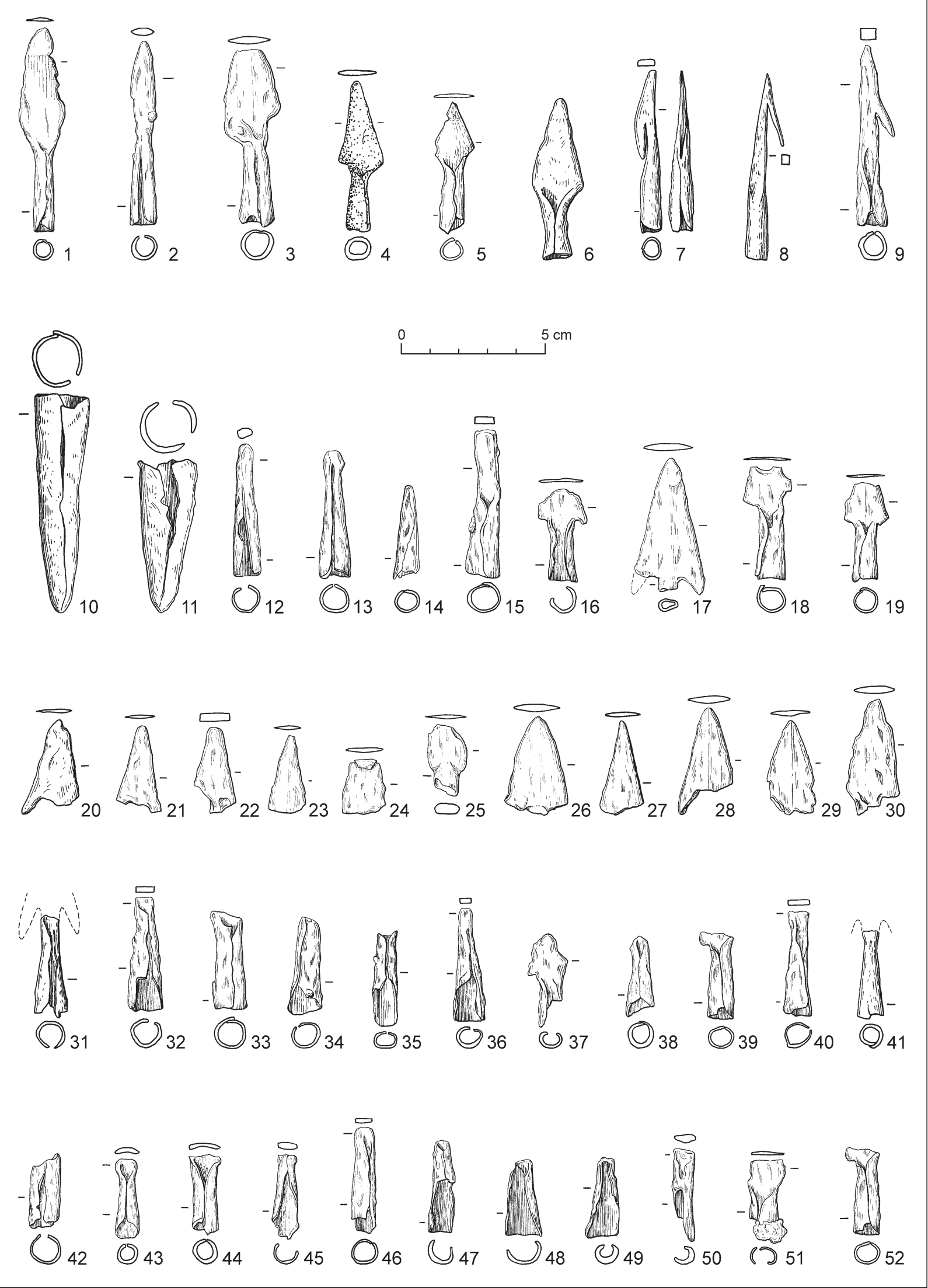

Fig. 14. Bytča-Hrabové. Arrowheads and spear butts from the hillfort and the area around the ramparts. Iron. 

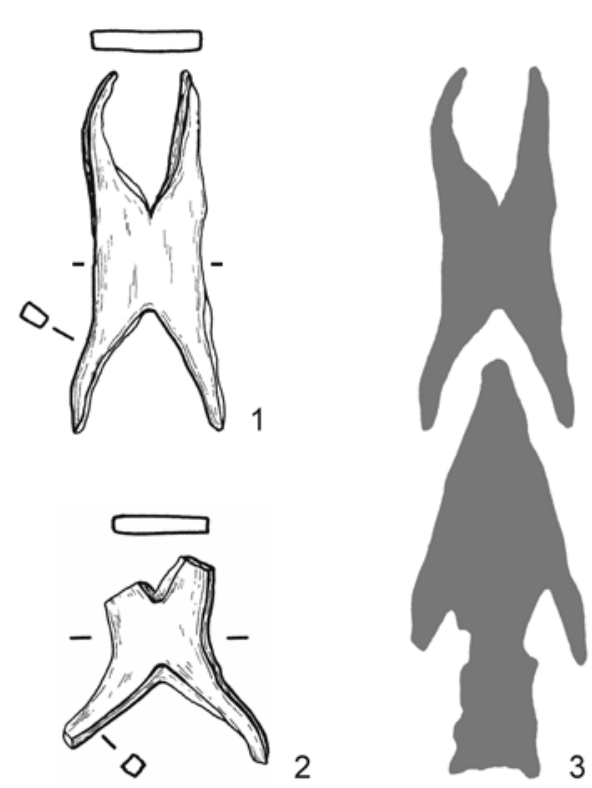

0 $3 \mathrm{~cm}$

Fig. 15. Bytča-Hrabové. Waste from the arrowheads production $(1,2)$ and its reconstruction (3). Iron.

were identified in private collections. The dominating type consists of arrowheads cut from a iron sheet with triangle leaf and back wings (type 1.2: Pieta 2010, 290-292). Less common type includes leaf-shaped arrowheads without wings. Only in two cases, the arrowheads were forged rectangular in the intersection with only back hook - useful against warriors wearing some protective attire (type 3: Pieta 2010, 290-292). Two fragments of an iron sheet strip (Fig. 15) show traces of cutting triangle shapes. Most likely these two are wastes from the production of iron arrowheads that were manufactured directly at the site, as other traces of blacksmithing confirm. We can assume that (most) of the arrowheads found at the site were shot by the aggressors. The issue who - apart from the local people - used such arrowheads is related to another unanswered question, namely who caused the abrupt extinction of Púchov fortifications at the beginning of the Roman Period (Pieta 2009, 286). A truly unique find discovered during the research was a set of seven arrowheads (Fig. 13: 8, 34, 45-48, 52) found close to each other - undoubtedly forming equipment of a quiver or a deposit of arrowheads.

\section{Varia}

Other artefacts that should arouse interest are lead weight (Fig. 11: 8). These provide a relatively unique confirmation that the local people used scales (Pieta 2010, 264). Lead weights were very popular in the Roman Period (Aßkamp/Rudnick 2007).

The strike-a-light found at the site (Fig. 11: 6) has good analogies among finds from Germanic graves attributed to the Early Roman Period but also in the Sarmatian milieu (v. Carnap-Bornheim 2002; Istvánovics/Kulcsár 2017). We found such items also at sites belonging to the Púchov culture (Liptovská Mara III, Spišské Tomášovce, Stupné - Ježišková/Pieta 2019, fig. 5: 17). Needle-shaped strike-a-lights such as the one from hoard 2 (Fig. 9: 9) were used mainly in areas settled by the Germanic tribes (Ilkiaer 1993, 253-255).

\section{Pottery}

Within the fortification perimeter and on the slopes below we have found 120 fragments of vessels. The vast majority of the shreds are rough, hand-made barrel-shaped vessels with a slightly spaced bottom. Some fragments were decorated with simple, vertical grooves. The material contains a mixture of medium-sized quartzite grains as well as limestone pieces, secondarily burnt out. Exceptionally, we have found also fragments of bowls made of finer material. Based on the production process, profiles and decoration, we can assume that all the shreds should be attributed to the Early Roman Age.

\section{MIKUŠOVCE}

The Mikušovce (district Ilava) village cadastre with several significant sites, including urnfields dated back to the Late and Final Bronze Age, belonged to the most densely populated areas in the Váh valley. In those times, the local people used the fortified upland named Skalice composed of several facilities (Fig. 16). So far, this fortified settlement area has not been thoroughly mapped (ZajacoválPivovarová 2015). It covers sites such as Vel'ké hradište, Malé hradište (culture national monument) and Mokrá skala. To the north-east of Malé hradište $(531 \mathrm{~m})$, there is a steep conical hill covered with limestone rocks referred to as Malý hrádok or Hrby (Fig. 17). Slopes on the eastern and southern side are rocky or grassy, but most of the hill surface is covered either with scrubs or young pine forest.

The site was probably discovered by E. Poliak in 1961 (Petrovský-Šichman 1965, 58, 59). In 2005, 2011, 2014 and 2017, the author of the paper with colleagues - primarily J. Somr - performed several surface prospections. As a consequence, we have obtained a collection of finds including ceramics, 


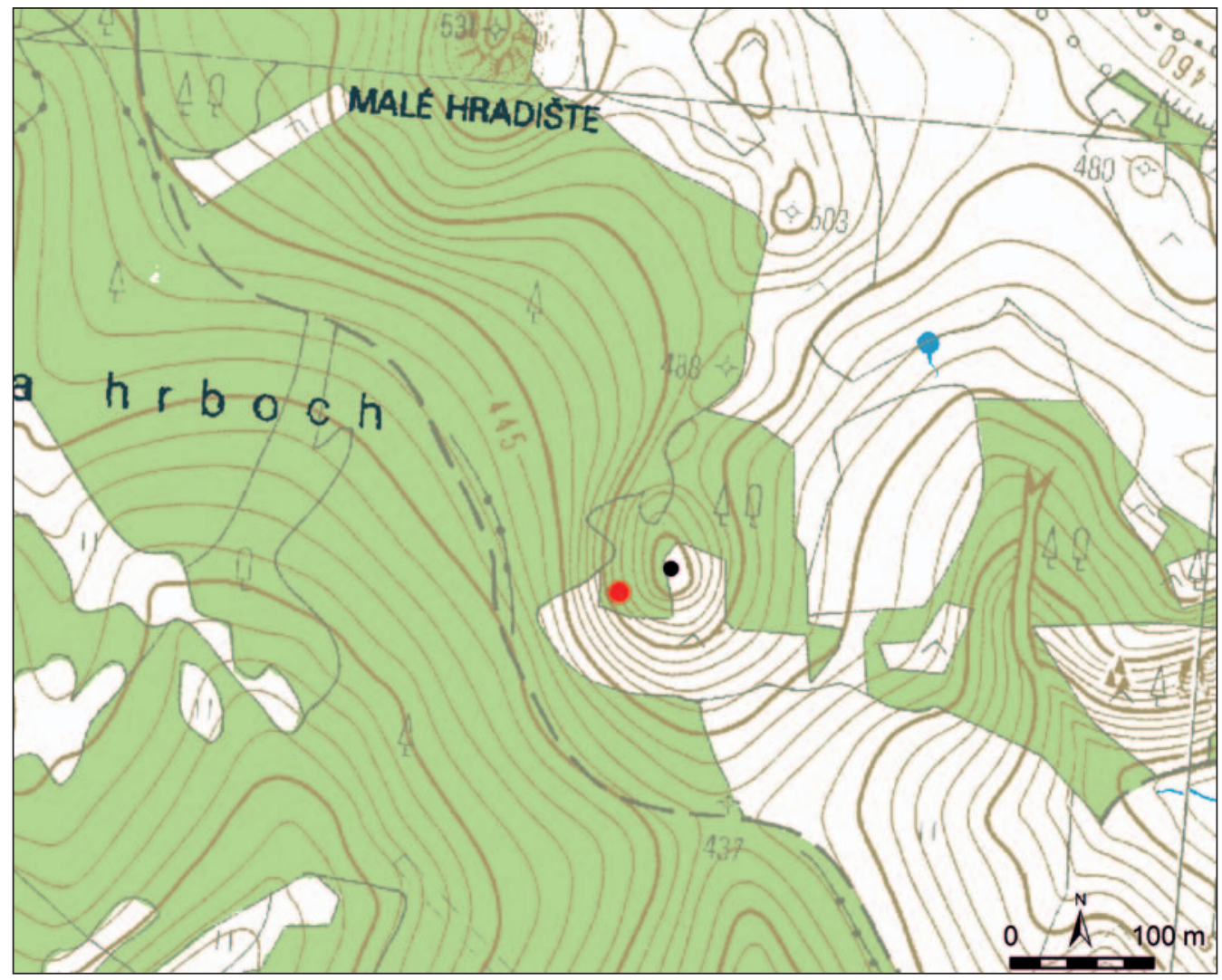

Fig. 16. Mikušovce. Black mark - the Malý hrádok hillfort; red mark - location of graves 1 and 2.

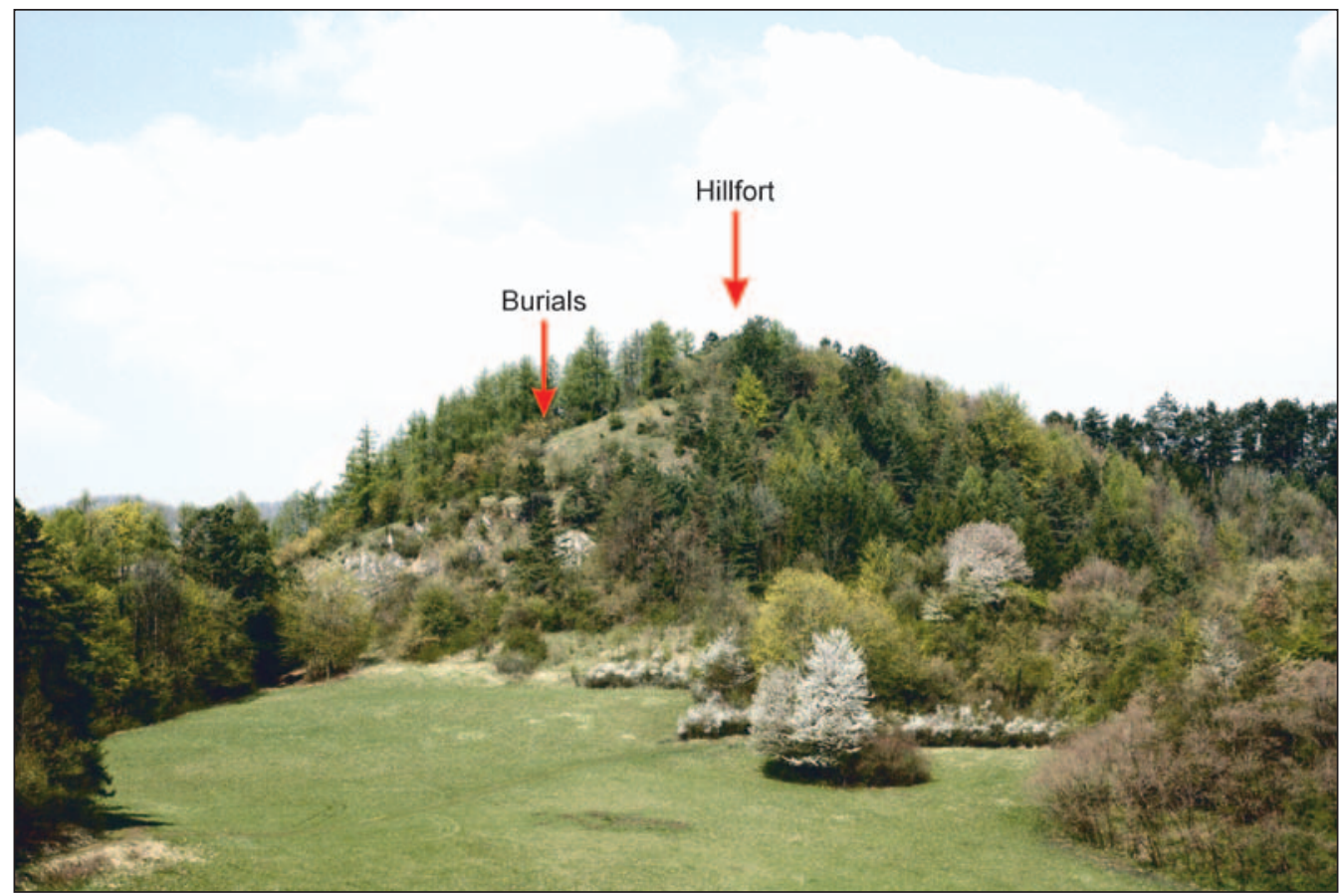

Fig. 17. Mikušovce, Malý hrádok. View from the south with the location of graves and the hillfort marked. 

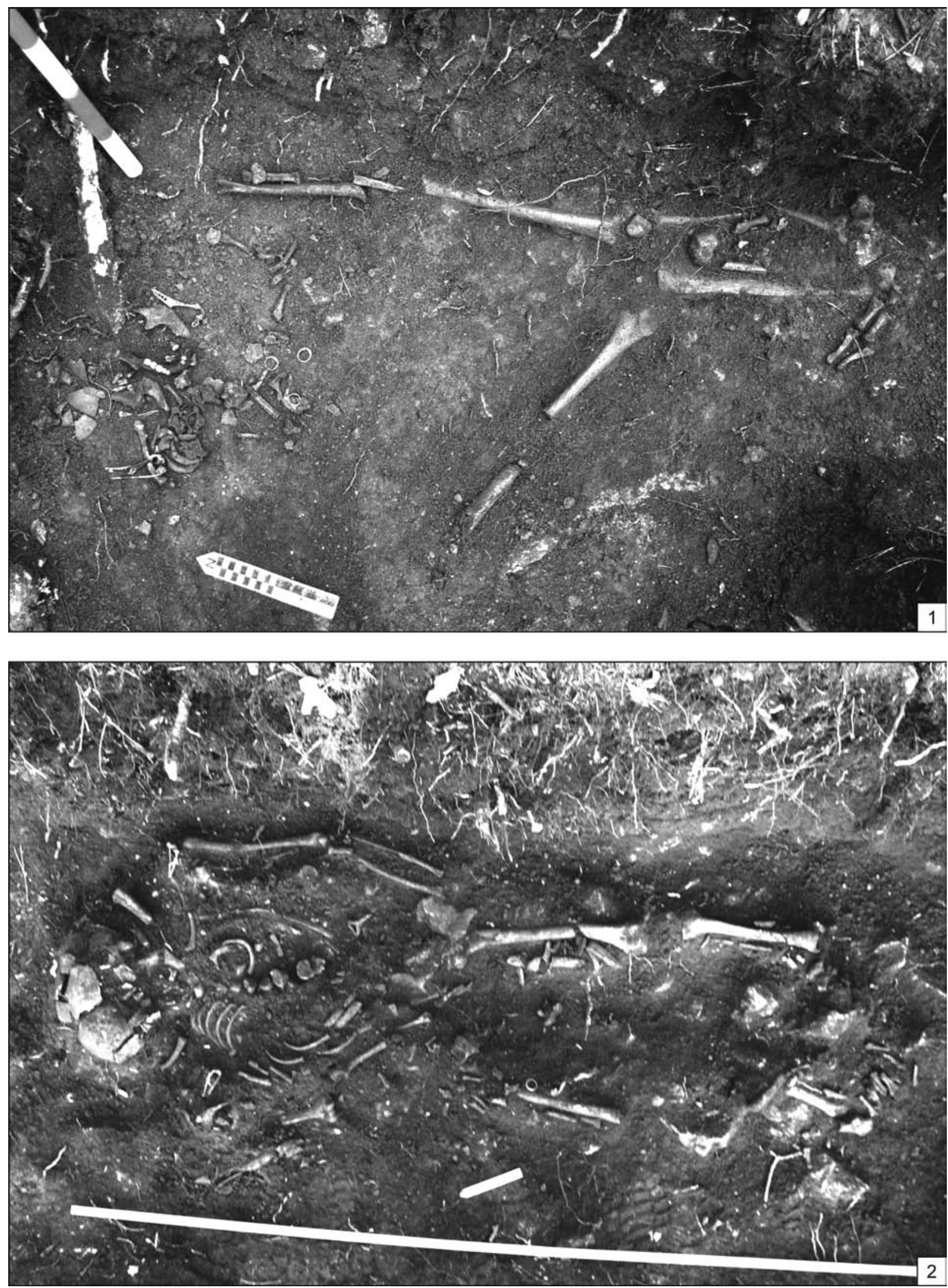

Fig. 18. Mikušovce. 1 - Grave 1; 2 - Grave 2. 


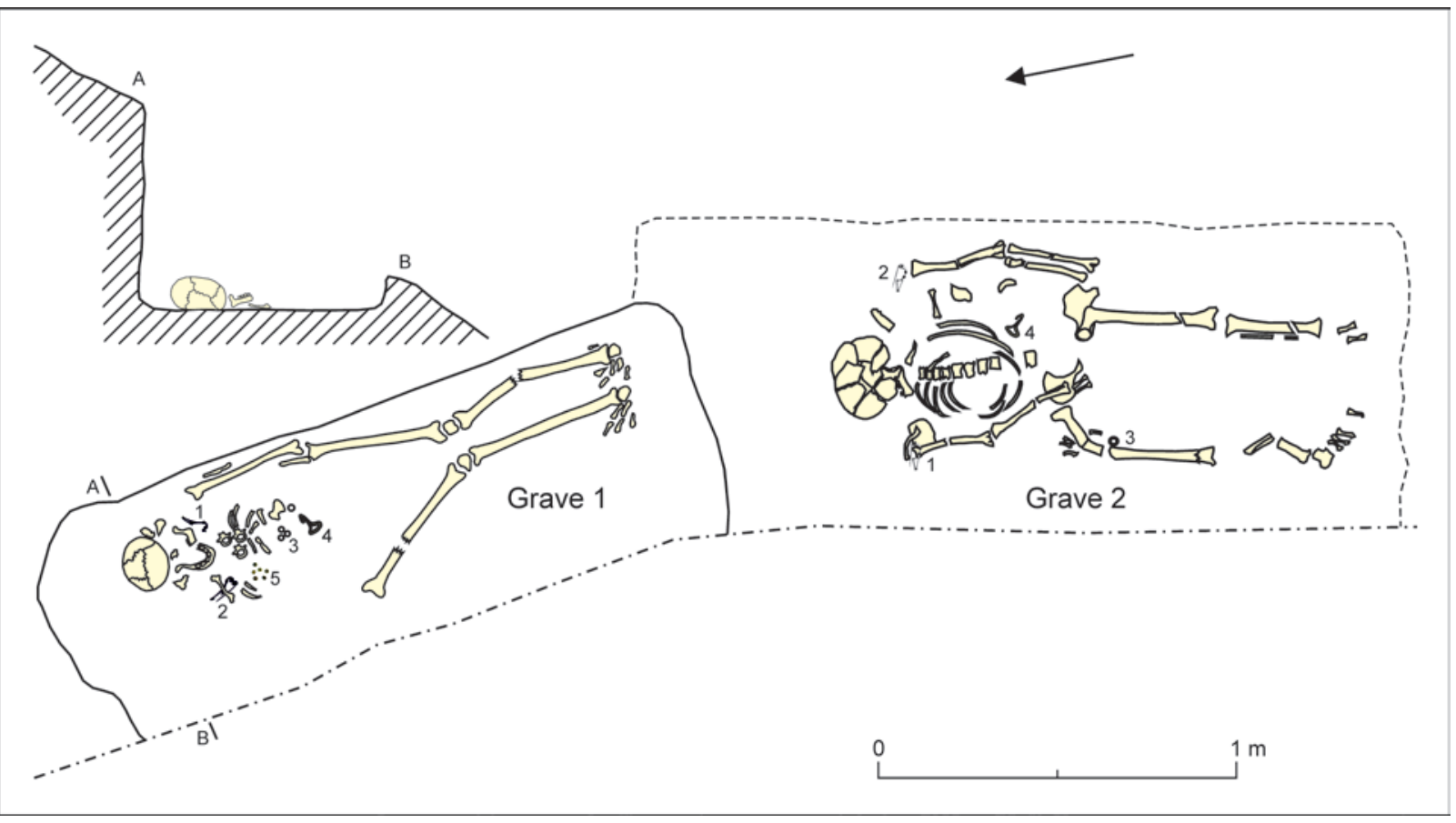

Fig. 19. Mikušovce. Grave 1 and grave 2.

animal bones and metal artefacts, samples for radiocarbon analyses and saved two skeletal graves from destruction. The site, similarly as the entire Skalice area, used to be a popular destination among amateur explorers who considerably damaged the site.

The summit plateau of Malý hrádok $(500 \mathrm{~m}$ a. s. 1.) is a narrow rectangle oriented to the southnorth. It is about 7-10 $\mathrm{m}$ wide and $30 \mathrm{~m}$ long and its edges are surrounded by faintly visible ramparts. At the south edge of the site, we can notice traces of a road - probably the original serpentine-like entrance - that accessed the site from the west. On the southern side of the summit, there is an almost square elevation, heavily damaged by modern digs. In its middle, there is a large pit, now filled with stones. The shape resembles foundations of a tower-like construction. The northern part of the site is also covered with illegal trenches abounding in pottery and pebble.

The western slope of the hill, under an eroded limestone rock, ends with a talus. The steep central and upper part of the slope is interwoven with rock crests but most of the surface is covered with a layer of forest soil of various thickness. It is here that all the so far known graves were discovered. The eastern slope is also steep, however, at the foot of the hill, we can notice traces of two terraces. A hoard of nine silver coins of the Vel'ký Bysterec type was found in the south-eastern part of the slope. The hoard was scattered along 4-5 m down the slope.

\section{Grave 1}

On November 18, 2010, an anonymous voice on telephone reported a find of human bones on the southern slope of Malý Hrádok. Jaroslav Somr from the Museum of Trenčín discovered here a skeleton with pieces of equipment that, except for a part of the body and the right arm, was intact. The grave was fixed with the GPS system and documented (Fig. 18: 1). The skeleton was placed in the upper part of the exceptionally steep south-eastern slope, $486 \mathrm{~m}$ above the sea level. The grave was oriented along the N/NW - S/SE axis with the head oriented to the north. In its lower part, it was about $50-55 \mathrm{~cm}$ deep, while in the upper part it was $15-20 \mathrm{~cm}$ deep. The skeleton laid stretched on its back, with the head slightly bent to the west. Its left hand laid straight along the body, the soil around the right hand and the torso was disrupted by the amateur exploration. The entire right side of the skeleton was slightly dislocated due to soil erosion which is confirmed by the position of the right femur moved away from the body, down the slope. In this damaged part of the grave, also fragments of an infant's skull have been found. There were also animal bones (sheep/goat metatarsal bones. Analysis Z. Bielichová) which original position, however, in the grave is unknown.

At both sides of the adult's skull, there were bronze brooches, foot up (Fig. 19; grave 1: 1, 2). On the right side, one of the fibulas laid directly on the 


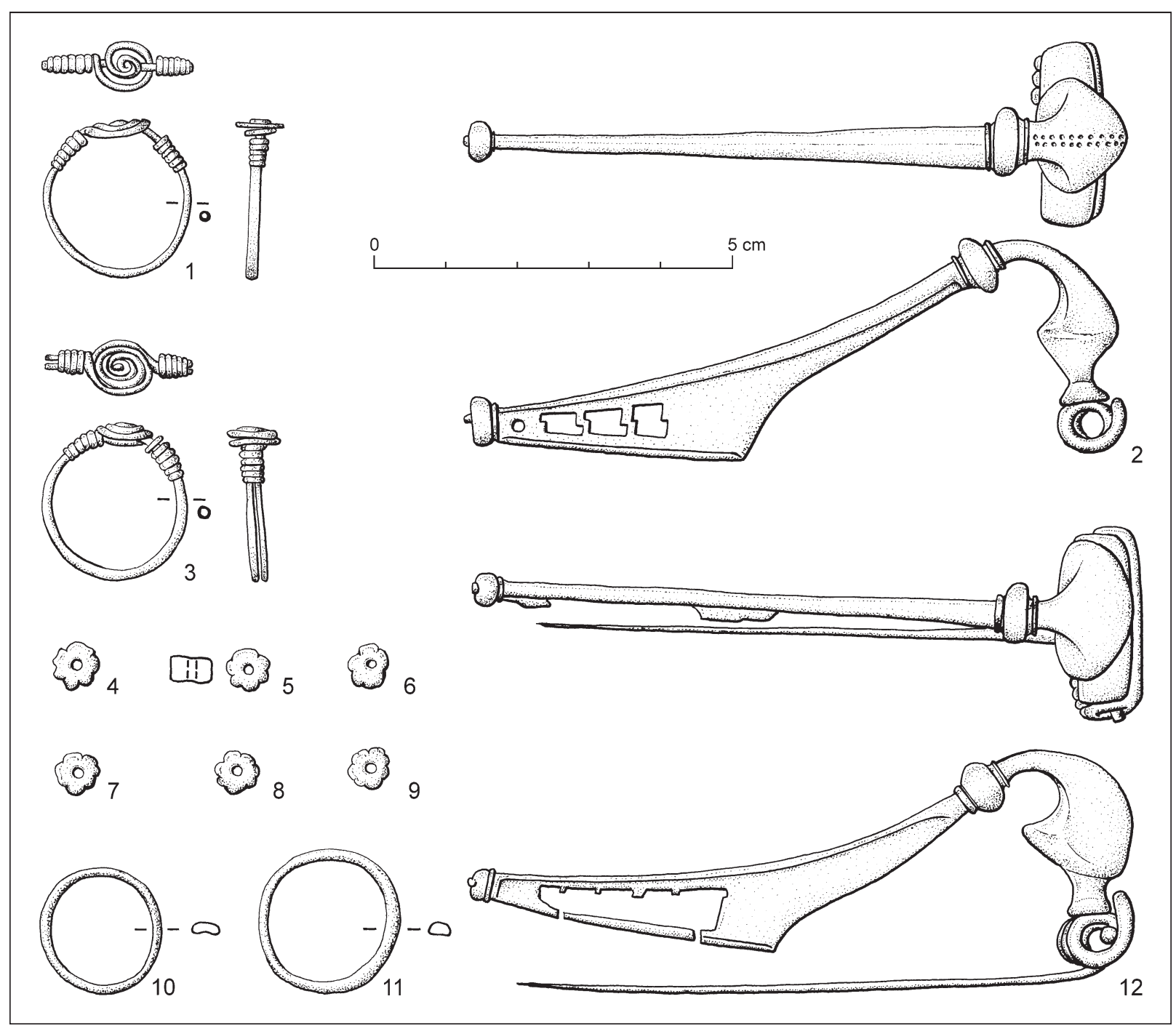

Fig. 20. Mikušovce. Grave 1 inventory. 1-3, 10-12 - bronze; 4-9 - glass and gold foil.

collarbone. Around the top of the chest, they were six melon-shaped beads made of transparent glass with gold foil (Fig. 19; grave 1: 5). In a secondary position close to the right hand, there were four bronze finger rings - two simple rings (bands) and two made of wire with a spiral crown and an adjustable band (Fig. 19; grave 1: 3). Around the waist, on poorly preserved pelvic bones, was an iron belt clasp with a triangular frame which, unfortunately, was not preserved (Fig. 19; grave 1: 4). The fibulas belong to the Almgren 67 type. One of them - typologically slightly older - has a broken spiral repaired with a bronze axis. Finds from the grave are deposited in the Trenčín Museum. The osteological material is kept at the Institute of Archaeology SAS in Nitra.

In accordance with the anthropological analysis (J. Jakab), skeleton belonged to an adult of unspecified age (adultus I, 20-30-year-old) with poorly developed muscles. The body height remains unknown. Remain of a scull belong to an infant (infans I).

\section{The inventory (Fig. 20)}

Brooch A 67a (according to Garbsch and Demetz) with a massive head over a protective plaque with an eightfold spring. A structured, spherical knot passes into a long, arched pin ended with a spherical button. A long, damaged catch plate was gradually, fivefold perforated. The item was made of bronze and $99 \mathrm{~mm}$ long (Fig. 20: 12).

- Brooch A 67a with a massive head decorated with a double, dotted line over the plaque with an eightfold spring. A structured, spherical knot passes into a long, arched foot ended 
with a spherical button. A long catch plate was perforated with three circular openings in the narrower part. Part of the spiral as well as the needle are missing - most likely there were lost due to unprofessional handling during amateur exploration. The item was made of bronze and $97 \mathrm{~mm}$ long (Fig. 20: 2).

- Cylindrical beads with vertically folded sides made of transparent glass with gold foil. 6 pieces, $7 \mathrm{~mm}$ wide and $4 \mathrm{~mm}$ high (Fig. 20: 4-9).

- Wire ring with an oval crown and a double band with both ends wrapped. The item was made of bronze with an internal diameter of $18 \mathrm{~mm}$. The wire is 1-2 mm wide (Fig. 20: 1).

- Wire ring with an oval crown and a simple band with both ends coiled around. The item was made of bronze with the internal diameter of $18-19 \mathrm{~mm}$. The wire is $1-2 \mathrm{~mm}$ wide (Fig. 20: 3).

- Flat ring (band) made of bronze, $2 \times 3 \mathrm{~mm}$ in the intersection with the internal diameter of $18 \mathrm{~mm}$ (Fig. 20: 11).

- Flat ring (band) made of bronze, $2 \times 5 \mathrm{~mm}$ in the intersection with the internal diameter of $15 \mathrm{~mm}$ (Fig. 20: 10).

- Belt clasp with a triangular frame and a long arm ended with a hook. The item was not preserved. Dimensions unknown.

\section{Grave 2}

On April 14, 2011, the site was inspected. The aim of the inspection was to verify the abovedescribed find and to control preservation of the entire site. We found that the upper part of the hill was cleared of bushes and in numerous spots were traces of illegal exploration to see, together with small piles of pottery shreds left on the surface together with numerous pieces of pebble - originally used as cartridges. Even on the forested southern and eastern slopes, we detected numerous pits - traces of metal detector search. The entire site was considerably damaged and systematically plundered.

On the site of the grave 1, we uncovered again the pit from 2010 and this extended in its southeastern part (around the original position of the skeleton legs). In this additional trench, in a layer of red-yellow soil, we found many prehistoric pottery shreds unrelated to the graves. In the distance of $80 \mathrm{~cm}$ from the legs of skeleton 1, skull of another skeleton in a layer of black humus soil have been detected (Fig. 18: 2; 19).

The grave 2 was also situated on a steep (up to $30^{\circ}$ ), rocky slope covered with vegetation. Lime- stone bedrock can be seen on the surface in several places. The soil here is humus-like, loose and dark. Similarly as the grave 1, the burial laid parallel to the slope. Towards the slope was the grave $50-55 \mathrm{~cm}$ deep, while the right (western) part was only $10-15 \mathrm{~cm}$ beneath the surface. The grave fill was heavily overgrown with roots that compromised the skeleton position, particularly its right side and all flat bones (shoulder blades, pelvis) as well as the skull.

After cleaning the skeleton carefully, we found that the deceased was buried in black humus, straight on its back with legs laid side by side. The body was oriented with the head to the N/NE. The left arm was placed along the body, while the right, heavily damaged hand was placed closer to the pelvis. The skull was placed on the left side and seriously damaged facial bones were partially covered with a long, animal bone.

According to the anthropological analysis (J. Jak$\mathrm{ab})$, the skeleton belonged to a short $(148 \mathrm{~cm})$, adult women (adultus I, 20-30-year-old).

On the right side of the shoulder, there was a bronze fibula (Fig. 19; grave 2: 1) and an identical specimen was found, backside up, on the left collar bone (Fig. 19; grave 2: 2). On the right side of the pelvis, we have found a plain bronze ring (Fig. 19; grave 2:3), originally placed on the poorly preserved right hand. In the lower left part, below the chest, there was an iron belt clasp with a triangle frame (Fig. 19; grave 2: 4) placed in a horizontal position with its hooked facing inward toward the waist. Unidentified animal bones were found around the right hand.

\section{The inventory (Fig. 21)}

- Brooch A 236C (Garbsch 236b2b1) on the right side of the shoulder with a massive head and two three-fold knots on a bow. A steep bow over the frame-like foot ends with a plain, double button. The item was made was bronze and $61 \mathrm{~mm}$ long (Fig. 21: 1).

- Brooch A 236C (Garbsch 236b2b1) on the left side of the shoulder with a massive head and two three-fold knots on a bow. A steep bow over the frame-like foot ends with a plain, double button. The item was made was bronze and $58 \mathrm{~mm}$ long (Fig. 21: 2).

- Plain ring (band), flat in the intersection. The item was made of bronze, $3 \times 1 \mathrm{~mm}$ in the intersection with the internal diameter of $18 \mathrm{~mm}$ (Fig. 21: 3).

- Belt clasp made of iron, with a narrow, triangular frame and a long arm ended with a hook was made of iron and was $47 \mathrm{~mm}$ long (Fig. 21: 4). 


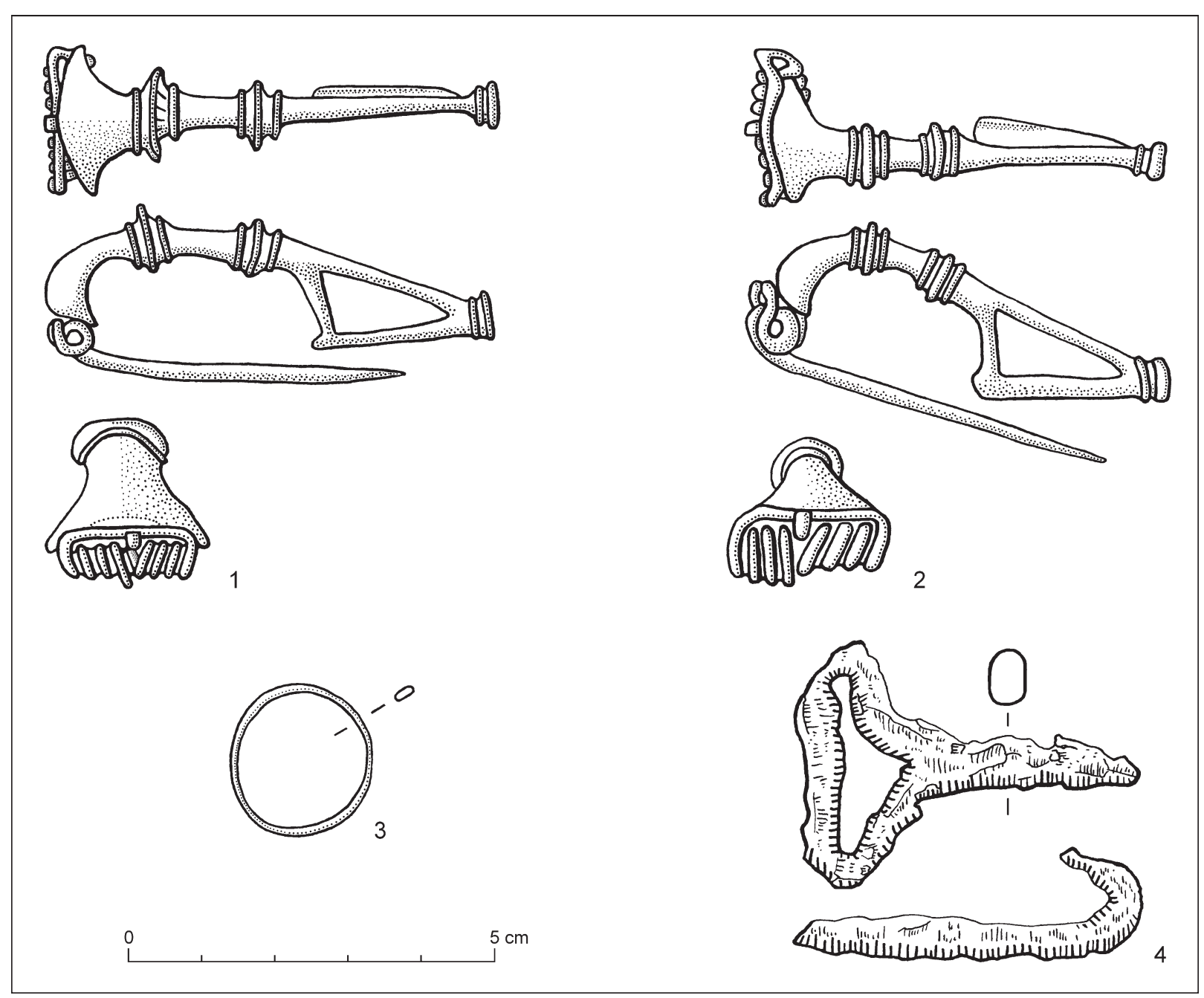

Fig. 21. Mikušovce. Grave 2 inventory. 1-3 - bronze; 4 - iron.

\section{Grave 3}

The skeletal grave 3 at the Mikušovce, Malý hrádok site has been found already in 2001. It was until the end of 2017, however, that the detailed information about the find got to the archaeologists. The discoverers became interested in nonferrous metal signals from their detector on the steep southern slope just below the summit plateau. According to the relation of bystanders who observed (and photographed) the exploration, the grave was found between graves 1/2010 and 2/2011 and the fortified summit. The spot is marked by a recess that remained after the trench was filled. The skeleton laid parallel to the slope. Allegedly, next to the grave the explorers heard another signal and found child's ribs which they left on the site uninspected. This information, however, we failed to confirm.

According to two, well-preserved photos dated August 8 and 10 (Fig. 22), about $40-80 \mathrm{~cm}$ below the surface, the explorers carefully cleaned the skeleton (from its head to the knees). The skeleton was in relatively good shape and laid straight on its back. Around the waist, the skeleton was sufficiently cleaned at both sides. The head area and lower parts of legs were covered with soil and thus we do not know whether they were later cleaned. The photo made on August 8 shows left femur (broken in two points) and a fragment of right femur, left shoulder bones, a collar bone and ribs. It seems that the works were continued two days later. The photo made on August 10 shows the left humerus and chest. In the upper part, we can notice two bronze pincer-like fibulae feet oriented upwards. The head area was still covered with soil.

According to the witness and a simple sketch, there was a small broken vessel next to the head. The vessel, unfortunately, was not preserved. Bronze fibulae (type A 238) were placed on both shoulders and a small bronze brooch (type A 67-68) laid just below the chin. The bronze belt fittings were found 

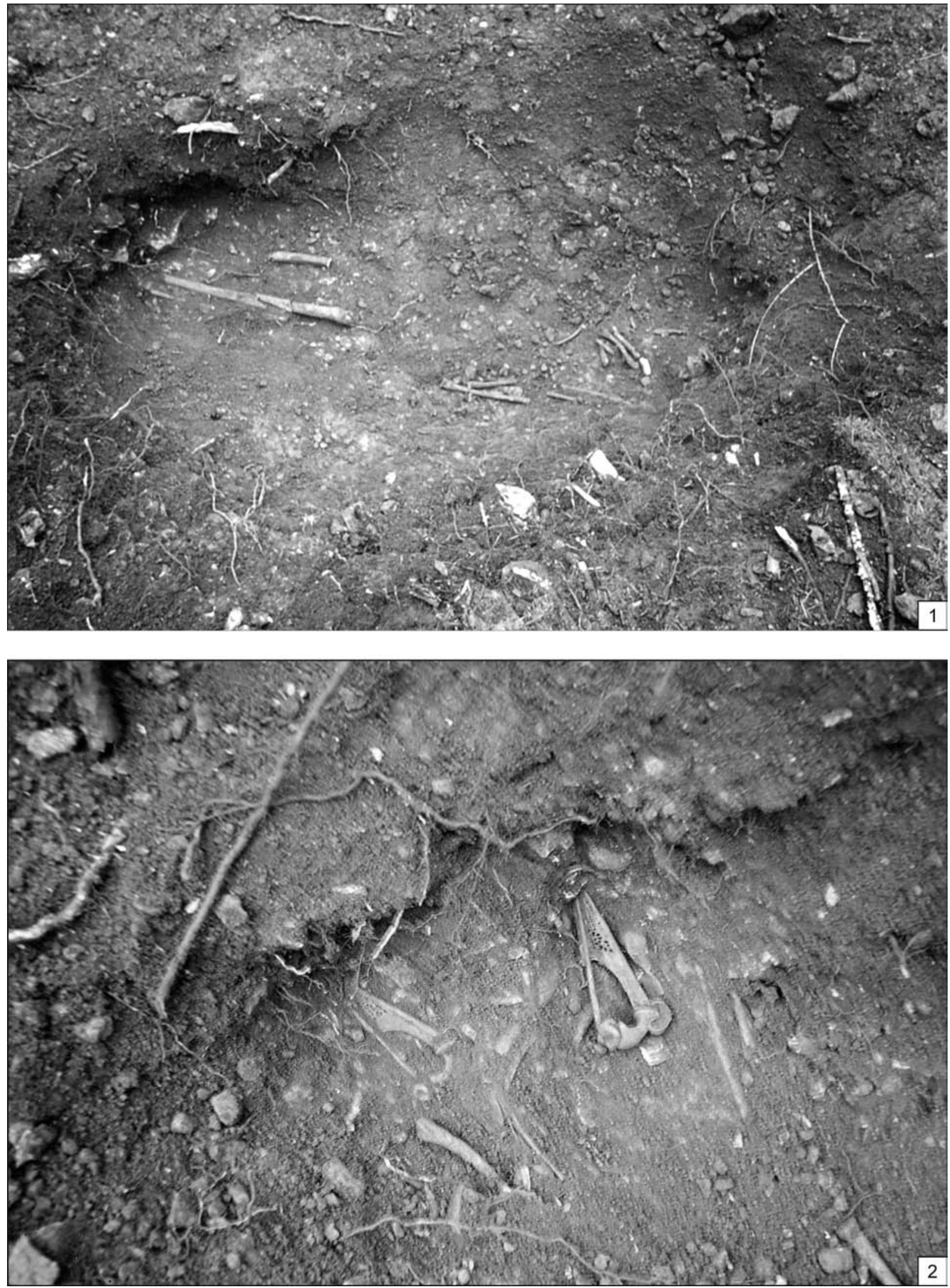

Fig. 22. Mikušovce. Grave 3. Photos from the amateur exploration of the grave. 
on pelvis: a hooked clasp, a perforated plaque, a boat-shaped fitting and numerous decorative flatheaded rivets. Next to the clasp, on the left side of the pelvis - under the left-hand bones - there was a pseudo filigree bronze circular pendant and a blue glass bead with yellow inclusions. By the femur, there was an iron arrowhead, placed about $2 \mathrm{~cm}$ from the bone pointing to the body.

The grave inventory is known from three photos and detailed sketches. We were able to acquire the iron arrowhead and bronze parts of the Noric-Pannonian belt including the openwork metal plaque, seventeen circular head rivets, five small decorative rivets and one boat-shaped fitting and two nails. Unfortunately, bones were not preserved.

\section{The inventory (Fig. 23)}

- Brooch (type A 238) from the left shoulder with a massive head, wide knot and a flat, prong-like application decorated with grooves and three rivets. Its bow is even, roof-like profiled, decorated with a row of impressions. The long catch plate is perforated with circular and square apertures with a radially arranged motif placed closer to the head. The eight-fold coil is fastened with a wide, decorated hook. The item was made of bronze and is $154 \mathrm{~mm}$ long (Fig. 23: 31).

- Brooch (type A 238) from the right shoulder with a massive head, wide knot and a flat, prong-like application decorated with grooves and three small insets. The bow is even, roof-like profiled, decorated with grooves. The long catch plate is perforated with circular and square apertures with a radially arranged motif placed closer to the head. The eight-fold coil is fastened with a wide, decorated hook. The item was made of bronze and is $154 \mathrm{~mm}$ long (Fig. 23: 33).

- Brooch A 67/68 with a massive head and a protective plaque over the six-fold coil. The item has a three-fold knot on the even foot, ended with a circular button. The catch plate is perforated with two steps. It was made of bronze and $60 \mathrm{~mm}$ long (Fig. 23: 34).

- Clasp with a flat oval frame decorated with ten circles made with compass tool. The longer part of the circular cross-section ends with a hook. The item was made of bronze and is $78 \mathrm{~mm}$ long (Fig. 23: 29).

- Plaque from a leather belt made of two bronze sheets linked with sets of four rivets. It has a flat head arranged in two rows. The plaque is heavily damaged. Its upper side is decorated with openwork and tubularly curved shorter sides. The inner side of the item is smooth. The dimensions are: 50 × $60 \mathrm{~mm}$ (Fig. 23: 1-4).
- Boat-shaped fitting with two fastening openings. Its tips plastically narrowed. The item is semicircular in the intersection and made of bronze. It is $50 \mathrm{~mm}$ long (Fig. 23: 5).

- Rivets with a rounded head and a curved pin. 5 pieces. The items were made of bronze. The head diameter is $6-7 \mathrm{~mm}$ and the pin is $5 \mathrm{~mm}$ long (Fig. 23: 24-28).

- Rivets with a rounded head and a curved pin. 17 pieces. The items were made of bronze. The head diameter is $15-16 \mathrm{~mm}$ and the pin is $5 \mathrm{~mm}$ long (Fig. 23: 7-23).

- Arrowhead made of an iron plate with a flat tip and ears oriented backwards with a long, curved notch. It is $43 \mathrm{~mm}$ long (Fig. 23: 6).

- Round bead slightly flattened with a wide opening. The item was made of blue glass with irregular yellow inclusions and was $26 \mathrm{~mm}$ wide (Fig. 23: 30).

- Disc-shaped pendant with a bail and an opening in the middle. The item was cast in a form and decorated with pseudo-filigree. It was made of bronze, $88 \mathrm{~mm}$ wide and $29 \mathrm{~mm}$ thick (Fig. 23: 32).

\section{The other finds from the hillfort Mikušovce-Malý hrádok}

The oldest horizon covers ceramics found during surveys between graves 1 and 2 . Sherds were parts of a thick-walls vessel with a horizontal, circular in intersection handle and at least two other vessels. A fragment of a tube-shaped vessel with a narrowed neck and a horizontal circular in intersection handle placed in the widest point of the vessel can belong to the Early Eneolithic Period, most likely to the late Lengyel culture.

The bronze fibula with a decorated foot (Fußzierfibel; Fig. 24: 1) of the Mansfeld type F1 could be attributed to the end of the Hallstatt Period (HD2/D3 Glunz 1997, 130-132; Mansfeld 1973, 37, pl. 26; Stöllner $2002,60)$. It is a isolated find at the site. The fibulae were manufactured in Heuneburg (Drescher 1995, 257, fig. 3). In the Western Carpathian region, so far, we know analogous fibulae from Blatnica (Bazovský 2003,185 ) as well as a new specimen, found on the hill fort Bojná V in 2019.

Most of the finds discovered during the surveys at the site belong to the La Tène and Early Roman Periods. Some of the items, including shred and fragments of querns, were handed in the Institute of Archaeology SAS by local explorers and employees of Forests of the Slovak Republic. Pottery shreds concentrate around the summit plateau. Large fragments of pottery in moved soil indicate that some features had been here damaged. This applies 


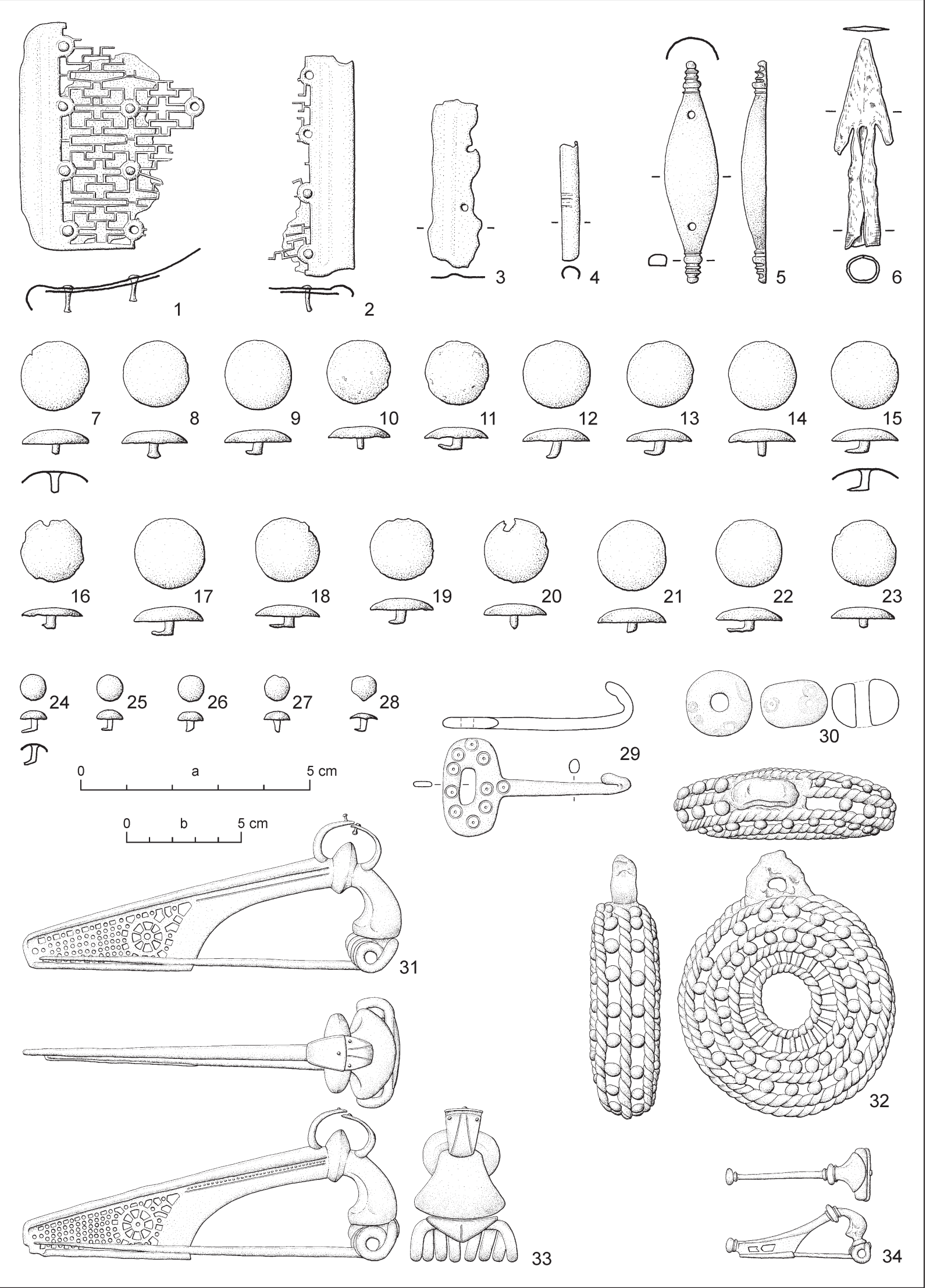

Fig. 23. Mikušovce. Grave 3 inventory. According to the finders, the arrowhead (6) was placed inside the body. 1-5, 7-29, 31-34 - bronze; 6 - iron; 30 - glass. Scale: $\mathrm{a}-1-28 ; \mathrm{b}-29-34$. 


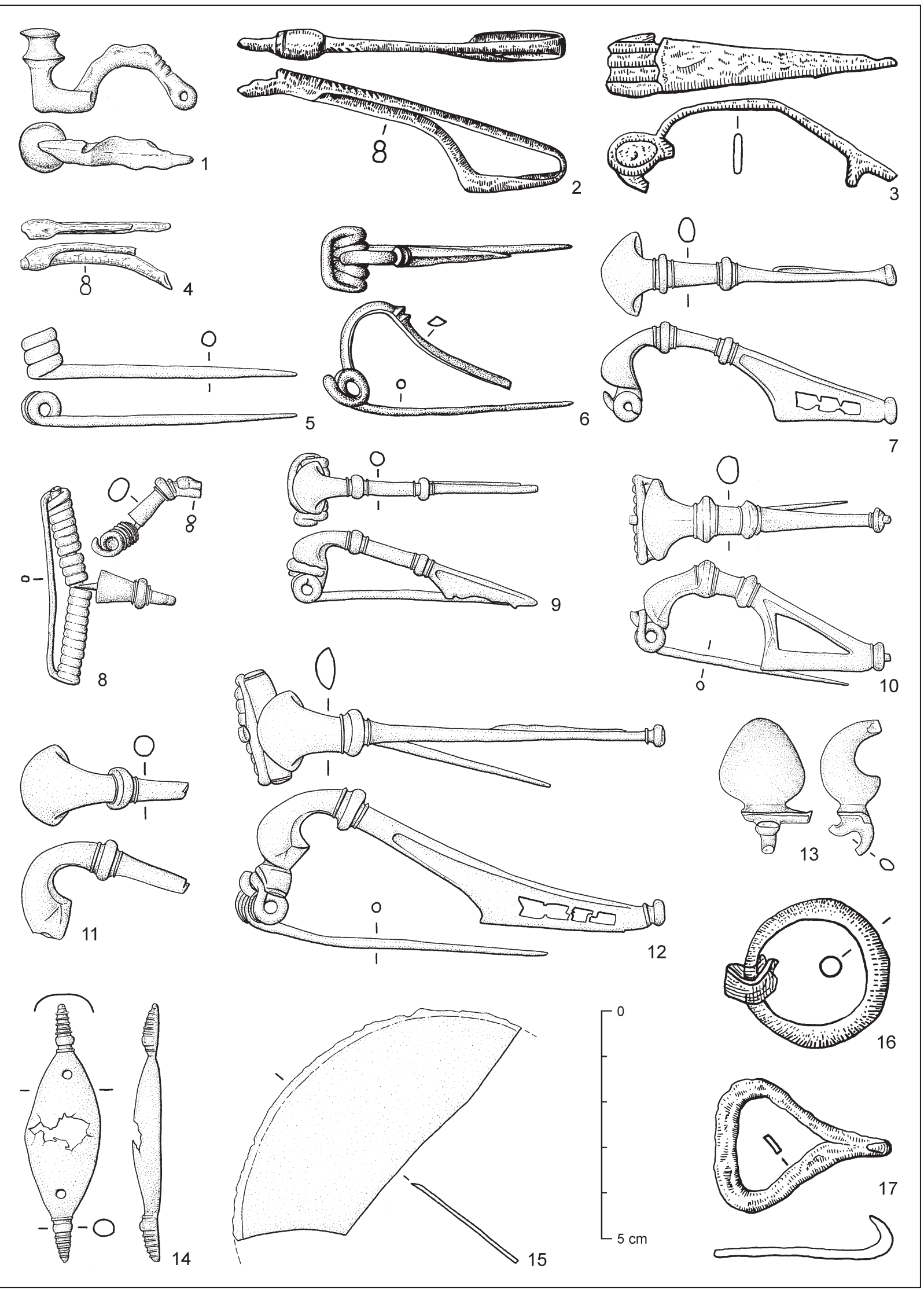

Fig. 24. Mikušovce. Finds from the hillfort and slopes of the hill. 1, 7-15 - bronze; 2-6, 16, 17 - iron. 


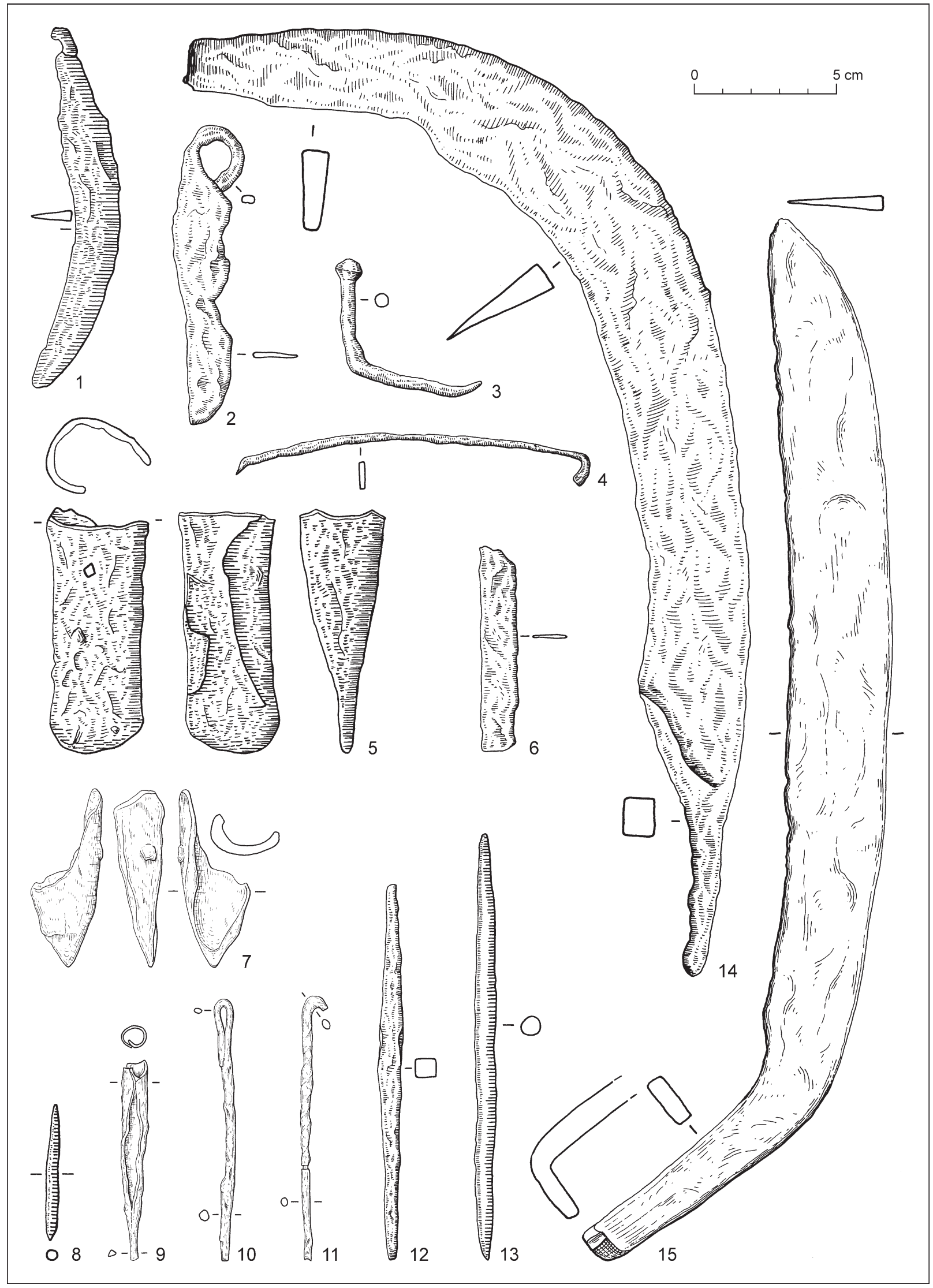

Fig. 25. Mikušovce. Implements and tools from the hillfort and slopes of the hill. All iron. 
mainly to fragments of storage vessels (dolia), but there are also shreds of hand-formed bowls and pots as well as single fragments of wheel thrown and graphite pottery. On the slopes, but mainly inside the fortification, there are also piles of pebbles.

According to various sources, two single coins were found at the site. A Vel'ký Bysterec type coin was found in the southern part inside of the fortification, while a Divinka type coin was found in the lower part of the eastern slope. A hoard of nine coins of the Vel'ky Bysterec type was also found in the middle part of the slope outside the rampart.

Chronologically, the La Tène settlement at the site is best represented by the collection of brooches.

Some types of fibulae have already been discussed in the characteristics of the above analysed Bytča-Hrabové site. These include plain MLT fibula made of wire (Fig. 24: 2, 4) with the foot fastened with a clamp. Such items were particularly popular in LTC2 and D1 stages but could be used for a relatively long time. An arched fibula with a belt-like bow (Fig. 24:3) is an item characteristic to the older Late Tène Period and also very common in entire Northern Slovakia. Specimens linked with the Púchov material culture were usually simple and made of iron. Afterwards, during the D2 stage, there are also fibulae with a bent bow (Fig. 24: 6).

The Oberleiserberg type fibula (Fig. 24: 8) has characteristic crossbow-shaped long spring and a massive head with a triple knot and an inset in a place where a foot is attached (Karwowski/Militky 2011, 133-135). The type is related to A65 brooch originating from Northern Italy where are attributed to the Late La Tène D1 and D2 (Danielisovál Militký 2014, 49, 50, with references Demetz 1999, 28; Sedlmayer 2009, 118). In the Middle Váh Basin, A65 fibulae coincide with oppida. Numerous finds from Trenčianske Bohuslavice (Pieta 2010, fig. 15: 24). Within the Púchov culture, are such artefacts known only from its north-western part (Belušské Slatiny; Divinka - Pieta 2010, fig. 118: 9; Udiča - Pieta 2006, fig. 2: 13). The specimen resembles the Magdalenska Gora type, distributed mainly in the Eastern Alpes (Dizdar/Božič 2010, 147-152).

Strongly profiled fibulae A 67 (Fig. 24: 11, 12) were found in grave 1 and, both entire specimens and fragments, in layers at the Malý hrádok site on the slopes below the ramparts. These items belong to a repeatedly analysed type of artefacts with a narrow chronological horizon but a wide distribution ranging from the original Alpine region to various parts of the Germanic Barbaricum and to the lands inhabited by the Dacians. In terms of chronology, such items could be attributed to the Middle Augustean to the Late Tiberian periods (cf. Demetz 1999, 127-135; Rustoiu 1997 for an overview).
Developmental features of these brooches - predecessors of A68 type - include the gradual reduction of size, robustness of the head and modification of the foot form. Together with it's a 236 variation, such fibulas form a leading Early Roman horizon of fibulae at the turn of the older and younger stages of the Púchov culture. Their frequent occurrence coincides partially with the abundance of finds in the so-called decline horizon of the hill forts but indicates also the strength of contacts between the local people and the region of Eastern Alps, where such fibulae were developed. Prior to the discovery of graves analysed in this paper, various variations of the A 67 type were known only from hillforts and open settlements (Blatnica, Divinka, Dolný Kubín-Vel'ký Bysterec, Liptovská Mara I, Liptovská Mara II, Púchov, Rajecké Teplice, Žilina-Vranie, Jasenica, Skalka nad Váhom, Košeca-Nozdrovice Kolníková-Kolník 2004, 19-25, with references Pieta 1997, 58, 59, fig. 7; 2014, 136). A 67 fibulae belonged to the burial equipment at both analysed sites.

Strongly profiled brooches with two knots A 236 (Fig. 24: 7, 10) are variants of A 67 fibulae. The distribution, as well as typological development and dating of these two types, are similar (Böhme-Schönberger 1998; Garbsch 1985). This type - particularly older forms A 236a and smaller specimens with a frame-like catch are strongly represented among finds attributed to the Púchov culture (KošecaNozdrovice, Trenčín - Pieta 2010, fig. 33: 2; Liptovská Mara I - Pieta 1982, tab. 7: 5a, b; Liptovská Mara II Pieta 2000, fig. 4: 4, 5; Púchov - Pieta 1982, tab. 9: 1; Rochovica, Žilina-Vranie - Kolníková/Kolník 2004, fig. 10: 5; Mošovce - Pieta 2014, 136). Apparently, such items were less extended in the Przeworsk Culture (Euczkiewicz 2009, 421, 422) and on the west Dacian sites (e.g. Zemplín, Mala Kopanja - Budinský-Kričkal Lamiová-Schmiedlová 1990, pl. XIV: 9; Kotigoroško 1989, pl. VIII: 24, 26). In the grave from Mikušovce, two matching fibulae of this type were found on the deceased shoulders.

Tools and instruments, as well as other utility items from the hillfort (Fig. 25), are represented by two scythes and a ploughshare. These are supplemented by awls, a razor, a mirror fragment, hooks, needles and numerous fragments of querns. Metal finds are mainly arrowheads (Fig. 26): small arrowheads made of a metal plate with a socket and a triangle body with (or without) back ears. Many of the arrowheads are preserved fragmentarily.

Several intact items, for example A 67 and A 236 fibulae or the iron belt clasp, are identical to artefacts found in already known female graves. It seems likely that the finds could belong to assemblages from other burials damaged by the erosion or moved and discarded by treasure hunters. 


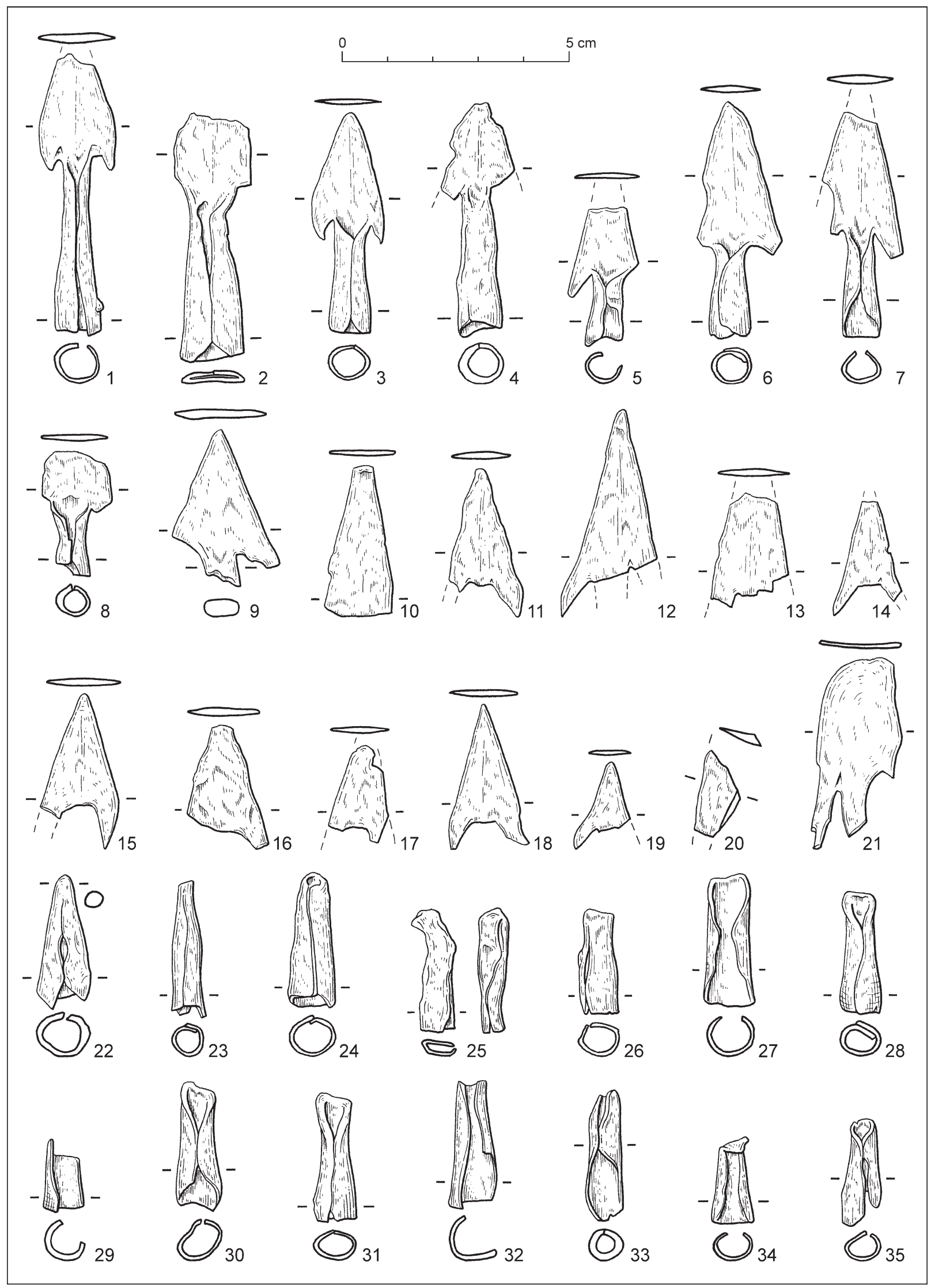

Fig. 26. Mikušovce. Arrowheads and arrowhead fragments. All iron. 


\section{LOCATION \\ AND GRAVE INVENTORIES}

Generally, in Bytča-Hrabové and Mikušovce, there are two graves placed next to each other and two graves with two bodies buried. All of the graves were skeletal and bodies laid straight on the back. Apart from the infant from Mikušovce grave 1, the skeletons belonged to women. At both sites, graves were dug on steep slopes outside the fortifications.

\section{Fibulae}

The deceased women was equipped mainly with metal and glass elements of attire consisting mainly of a pair of brooches on the shoulders, represented by the Noric-Pannonian brooches of type A 67, A 236 and A 238. The former two types were previously characterised in the context of settlement finds from both hillforts. The specimens found in the graves, although typologically different, can be unambiguously linked with older forms dated back to the B1a stage. Typologically the oldest artefacts (A 67a1) laid on the shoulders of about twenty-fiveyear-old female buried in grave 1 in Mikušovce. Graves 1 and 2 from Bytča (with bodies of about 20- and 40-year-old females) as well as in grave 3 from Mikušovce contained A $67 \mathrm{~b} 1$ fibulae dated back to the Early Tiberian Period (Demetz 1999, 135). Types A 67 and A 236 belong to finds characteristic of the decline horizon of hillforts attributed to the Púchov culture (Fig. 27: 1-3, 7-18).

Winged fibulae from grave 3 in Mikušovce belong to early forms of the A $238 \mathrm{~b}$ type (according to Garbsch) or the A 238b2 type (according to Demetz). Origins, distribution as well as the chronology of these fibulae have already received considerable attention (Bazovský 2017; Cambal 2017; Demetz 1999, 42-47; Garbsch 1985). It is believed that the A 238b2 type was manufactured in the second and third decades of the Current Era (Demetz 1999, 46).

\section{Belts}

Belts belonging to the deceased buried in grave 1 (Bytča) and grave 3 (Mikušovce) are examples of decorative sets. Unfortunately, some of the elements were lost - mainly clasps and fastening elements (Fig. 6: 10-29; 23: 1-5, 7-29). The Bytča specimen (Fig. 6: $28 \mathrm{a}-\mathrm{d}$ ) consisted of a clasp with two tongues (type G 2b) and a plaque decorated in opus interrasile technique (palmettes surrounded by two rows of rivets, type B5: Garbsch 1965). This type was popular not only by inhabitants of Noricum but also in Germanic, Dacian and Púchov milieus (Fig. 28: 5, 6; Pieta 2014, 151, 152, with references).
The woman buried in grave 3 (Mikušovce) was equipped with a leather belt with fittings typical for Noric-Pannonian belts which, however, was fastened with a bronze hooked clasp. Decorative motifs on the clasp (imprinted circles) are considered common in that time and are known from various types of metal belt elements closed with clasps or buckles (Fig. 9).

In more modestly equipped graves as Bytča 2 and Mikušovce 1 and 2, belts were fastened with simple iron hooked clasps with triangle frames (type Werner C; Fig. 21: 4). Since the Middle La Tène Period, when these clasps evolved from more complex La Tène metal belt clasps, iron clasps of this type were common elements of attire in the vast areas of Central and Western Europe (Bataille 2001). Hooked clasps were popular in the Púchov culture and are known from several settlements (KošecaNozdrovice, Podskalie, Stupné) and sacrificial sites (Liptovská Mara, Prosné, Trenčianske Teplice). This traditional Celtic product was used still at the beginning of the Roman Period as a part of the Germanic attire, undoubtedly to fasten simple, undecorated belts (Droberjar 2006, 32-35; Madyda-Legutko 1990, 159; Salač 2010, 362). The hooked clasps longevity is confirmed also by finds from Mikušovce and Bytča-Hrabové.

\section{Neck ring}

The woman's neck ring from grave 1 (Bytča) was made of an open iron ring wrapped with wire made of a tin alloy. Decorative necklaces belonged to the most popular types of decorations in the La Tène culture found in female graves but served also as symbolic ornaments - torques - on pictures showing male deities and heroes. In graves, such items belong to sets of ring jewellery, also in simple, iron variations (Bujna 2005, 112-114). In the Late La Tène Period and at the beginning of the Roman Period this type of adornments was common only in some areas, particularly in Noricum and Raetia. From these two regions, neck rings are known both from grave inventories and tombstones (Keller 1984, 31, 32).

During the La Tène Period - in the Western Carpathians - metal neck rings imitated Celtic open rings with buffer ends. During the older phase of the Púchov culture, such adornments were made of bronze - with simple stamp-like or multiple lentiform tips. There are also twisted neck rings torques - with end rings (Pieta 2000, fig. 5: 8; 2008, fig. 95: $6 ; 2012,319 ; 2014,137)$. The unique design of the neck ring from Bytča with the tin wire - resembling woven or twisted necklaces - imitated silver used in the necklaces production both in the Púchov 


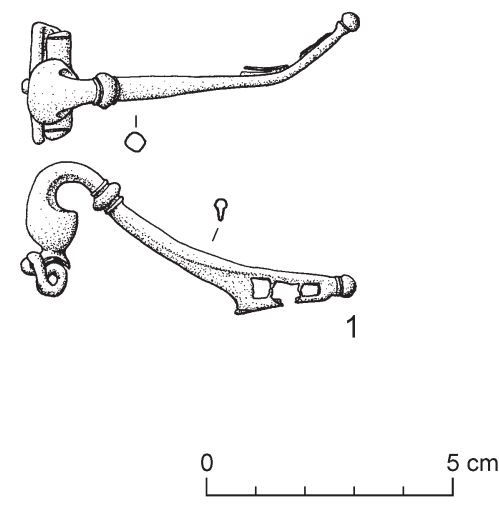

$\sum_{\frac{1}{1}}^{0}$

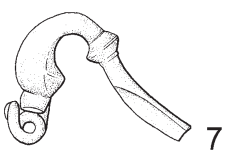

$\int_{0}^{3}$

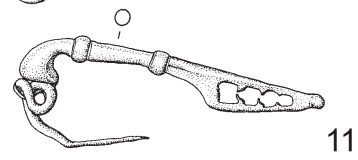

11
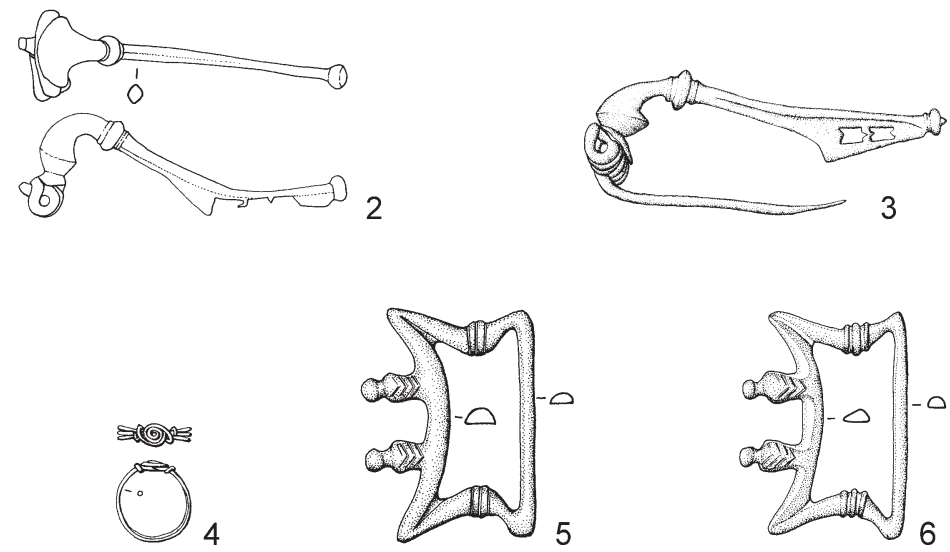
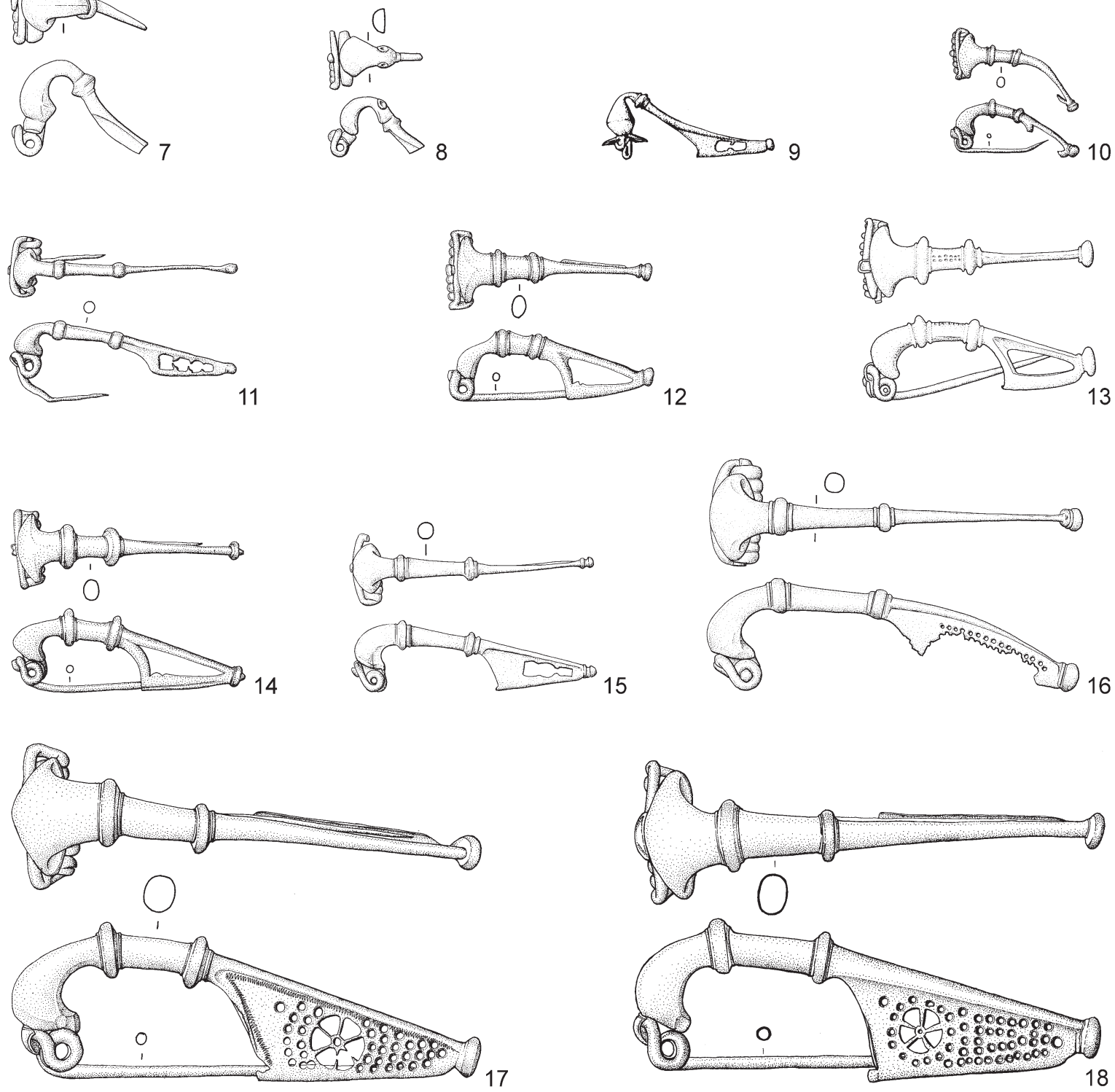

Fig. 27. Selected costume accessories and jewellery from Púchov culture settlements. 1,5 - Blatnica; 2, 3, 6-8, 11 - KošecaNozdrovice; 4 - Vrchteplá; 9 - Skalská Nová Ves; 10, 12, 14, 17, 18 - Folkušová a Necpaly; 13 - Púchov; 15, 16 - Mošovce. All bronze. 
culture and in the Noric-Pannonian environment (Garbsch 1965, 123; Pieta 2014, 137). An open iron neck ring from Liptovský Trnovec - bearing traces of being wrapped with a narrow, probably organic (leather?) strap - shows certain similarities with the Bytča specimen (Benediková/Pieta 2018a, 169). Unfortunately, the lack of similar finds prevents any conclusions about origins - local or foreign - of the custom to deposit such necklaces as a part of burial assemblages. However, we should remember that numerous Noric gravestones are depicted women with twisted neck rings. Simple neck rings with pointed ends or clasps are also known from peripheral areas during the Roman Period (Beckmann 1981, 16-18).

\section{Pearls}

Pearls belonged to the burial assemblages from graves 1 and 3 (Mikušovce). Six small melon-shaped pearls from grave 1 made of transparent glass with gold foil (goldüberfangene Perlen) belong to the XXIX group, type 387c. This widespread type started to appear in Barbaricum already in the Early Roman stage B1, but it became common in burials during stages B2 and C1 (Tempelmann-Maczyńska 1985, 64, 65). Judging by their location on the chest, we can assume that the pearls hung on the neck on a cord.

The dark blue bead with inclusions from grave 3 belongs to a relatively widespread group XXI. The colour is exceptional. Yellow inclusions arranged in numerous layers suggest that the item belongs to older variations known already in the B1 stage (Tempelmann-Maczyńska 1985, 51). The bead - together with a bronze disc-shaped pendant - was placed on the pelvis. Therefore, it seems that both items decorated a fancy belt fastened with a hooked clasp and decorated fittings, typical for the NoricPannonian sets.

\section{Disk-shaped pendant}

The bronze, disk-shaped pendant belongs to appealing adornments used in the Younger and Late La Tène period. Such pseudo-filigree decorations amulets - were lost-wax cast. Similar items are known from Western Slovakia (Bazovský 2014, 166) and from the Púchov culture area (Benediková/Pieta 2018b, fig. 4; Pieta 2010, fig. 134: 1; F21: 5; 2014, 137, fig. 7: 12). Used production technique corresponds with a large and varied group of cast basket-shaped pendants (v. Endert 1991, 20, 21). Numerous finds from Northern Slovakia confirm that such items were distributed particularly in the Púchov culture. However, the location of the pendant on the belt makes the find unique.

\section{Rings}

Rings were found in three graves. The older from the women buried in Bytča had three bronze wire rings with a spiral head and two narrow bands (Fig. 6:2-6). A similar combination of wire rings with adjustable ends and a spiral head was found in grave 1 in Mikušovce (Fig. 20: 1, 3, 10, 11). The modestly equipped female from grave 2 (Mikušovce) had only one simple band on her finger (Fig. 21: 3).

Rings as female hand jewellery had a relatively weak tradition in the mountainous area of Slovakia. Significant bronze saddle rings were found on pre-Púchov settlements from the early and Middle La Tène period (Bujna 2005, 144, 152; Pieta 2014, 135). On sites related to the Púchov culture, appear flat bands and imported antique rings with a head (Pieta 2010, fig. 119: 1-3). Due to the simplicity of construction and customizable size, wire rings with adjustable ends and a spiral head - type 16 according to Beckmann - were the very common type of jewellery since the end of the Iron Age until the Middle Ages (Fig. 28: 4; Beckmann 1969, 34). Some examples are known from oppida and primarily from early Roman sites in Raetia and Noricum (Deimel 1987, 64, pl. 46: 1-10; Keller 1984, 41), but were popular also in Barbaricum (Czarnecka 1989).

\section{Mirrors}

In the double grave from Bytča-Hrabové behind both females' heads, there were bronze mirrors which preserved only as metal discs -95 and $71 \mathrm{~mm}$ in diameter (Fig. 6: 7; 7:4). The item found by skeleton 2 was incomplete, however, due to the amateur exploration, it is impossible to determine whether the item was deposited as already broken or incomplete (as in some graves attributed to the Migration Period) or it was damaged during the exploration. There were no traces of a handle and thus we are entitled to assume that the mirrors were framed in organic, most likely wooden, not preserved settings. In the Late La Tène Period as well as in the Early Roman Period - in Central Europe - used mirrors were small and either put in a cassette or framed in a bronze handle. Comprehensive research on late La Tène hillforts and settlements in our region provided numerous finds of mirrors, mainly disc fragments, but also cast decorative handles (Pieta 1997, 48). Distribution of metal mirrors in the Middle Danube Region was so dense that it cannot be exclude the hypothesis that these items were manufactured locally.

The spread, application and importance of these toilet objects - but also symbolic artefacts was thoroughly discussed in the extant literature 


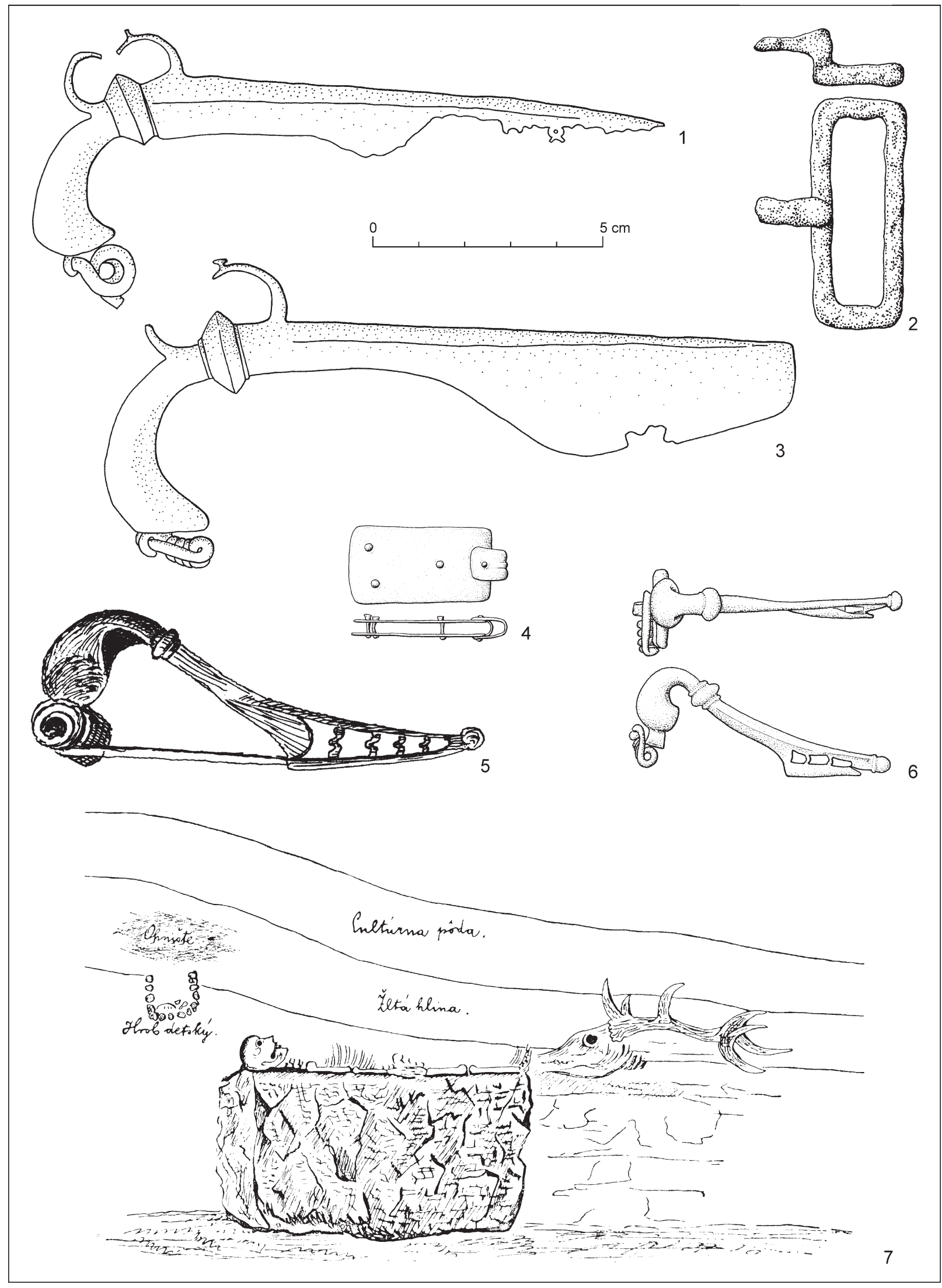

Fig. 28. Púchov. 1-6 - elements of the grave inventory from the E. Hoenning's survey (according to Prohászka 2017); 7 -sketch of grave 1 (according to Hoenning O'Caroll/Halaša 1903). 1, 3, 4-Slovak National Museum in Martin; 6-Naturhistorisches Museum Wien. 
(Niezabitowska-Wiśniewska 2012). Frequent images of mirrors on Noric tombs (Kvetánová 2006, 394, with references) and their common presence in Germanic graves attributed to the Early Roman Period are particularly informative for the present study. It can be assume that the custom to use mirrors was imported from the Eastern Alpine areas in the combination with metal elements of the so-called Noric-Pannonian costume (Adler 1976; Bemmann 1999, 165; Schuster 2010, 179-185; Zeman 2017, 146, with references). The two graves with mirrors from Bytča-Hrabové fit this context well.

\section{Spindle whorl, vessels and arrowhead}

So far, the spindle whorl made of graphite clay and a small bowl, placed between the bodies in the double grave in Bytča, are unique finds. Also in grave 3 in Mikušovce there was a small vessel which, however, was not preserved. Larger quantities of pottery shreds would help to solve the issue of origins of the graves. According to the finder, the iron arrowhead with a bent tip, found in grave 3 during amateur explorations, was placed just by the femur of the deceased. Due to the questionable context of the discovery, the question whether the deceased was injured or the arrowhead simply laid by the body - buried in an area with numerous pieces of weaponry left there after some battle - but was unrelated to the grave will remain unanswered.

\section{OTHER HUMAN SKELETONS FOUND WITHIN THE PÚCHOV CULTURE}

Púchov. First protohistoric graves within the Púchov culture had been found already at the end of the $19^{\text {th }} \mathrm{c}$. on the eponymous Skalka site in Púchov. According to the published records of E. Hoenning, six skeletal graves were found in the northern part of the hillfort. Skeleton 1, most likely a woman with an infant, laid straight on her back with a deer head by her legs (fig. 28: 7). In grave 2 - with an Almgren 67 fibula - bovine bones were found. There were no finds in grave 3. Skeleton 4 laid on its belly and there was no skull. Skeletons 5 and 6 were crouched burials (Beninger 1937, 61, 62; Hoenning O'Caroll/ Halaša 1903, 21, 22). Based on the records, we can assume that at least the grave 2 with brooch A 67 preserved together with the description of the find (Naturhistorisches Muzeum Wien, inv. no. 21 179; Fig. 28: 6) should be attributed to the Early Roman Period. Important pieces of information provided by P. Prohászka's research in archives shed new light on these graves. It turns out that $\mathrm{E}$. Hoenning found also further - previously never discussed in the literature - graves (Prohászka 2017). In his correspondence, the discoverer mentioned also a child's grave with two fibulae which, according to the archive drawings, belonged to the archaic form of the A 67 type (Prohászka 2017, fig. 4). It seems likely that the information refers to a bronze brooch pictured by E. Hoenning (see: Pieta 1982, pl. VII: 8).

According to the recently acquired documents, E. Hoenning found also other artefacts in the other graves. This applies particularly to a G1 type clasp (Fig. 28: 2; Bockius 1990; Garbsch 1965, 87; Pieta $1997,49,50)$ and a plaque, probably a fragment of a bronze omega-shaped buckle with three rivets and a double axis, belonging probably to type A16-18 (Fig. 28: 4; Madyda-Legutko 1987, 7, 8). In both cases, dating of these belt elements is consistent with the horizon of the Early Roman Period. The chronology of two wing fibulae - that according to the above mentioned source were found by the Púchov skeletons - remains less clear (fig. 28: 1, 3; Pieta 1982, 45, pl. IX: 4, 7). According to J. Garbsch, the A $238 \mathrm{r}$ brooch belongs to a group of simple products with an undecorated catch plate. Distribution of such items was limited to Barbaricum where the fibulae were either imported as semi-finished products or copied (Garbsch 1965, 78). In terms of size and dimensions of the head and knot as well as the small spring hook, both Púchov specimens belong to older variants of these relatively rare in the Púchov and Quadi environment fibulae. Therefore, the very presence of A 238 fibulae in skeletal graves (Mikušovce 3, Púchov?) is an exceptional finding that supports the hypothesis about the affinity with the NoricPannonian milieu.

The graves described here are clearly concentrated in the Middle Váh valley (Fig. 29). Other skeletal graves known from Púchov culture sites either cannot be dated with the accompanying inventories or the context of discovery cannot be reliably determined. Other 2-3 skeletal graves were found in Udiča-Okrut (district Považská Bystrica). Based on a spindle whorl found in one of the graves, V. Budinský-Krička dated the features back to the Roman Period (Petrovský-Šichman 1965, 66). In 1976, during research on a steep slope below the eastern terrace of the Havránok hillfort (Liptovská Mara I), we have found a female skeleton with an infant, without any accompanying inventory. The grave was dug into the destruction of the Late La Tène ramparts. In 2014 on the Hôrka hillfort near Lysica, district Žilina, scattered human bones were found. From this site, we know at least two hoards of Celtic coins (Pieta 2010, 218) and melted fragments of adornments (the information provided by J. Fröhlich). 


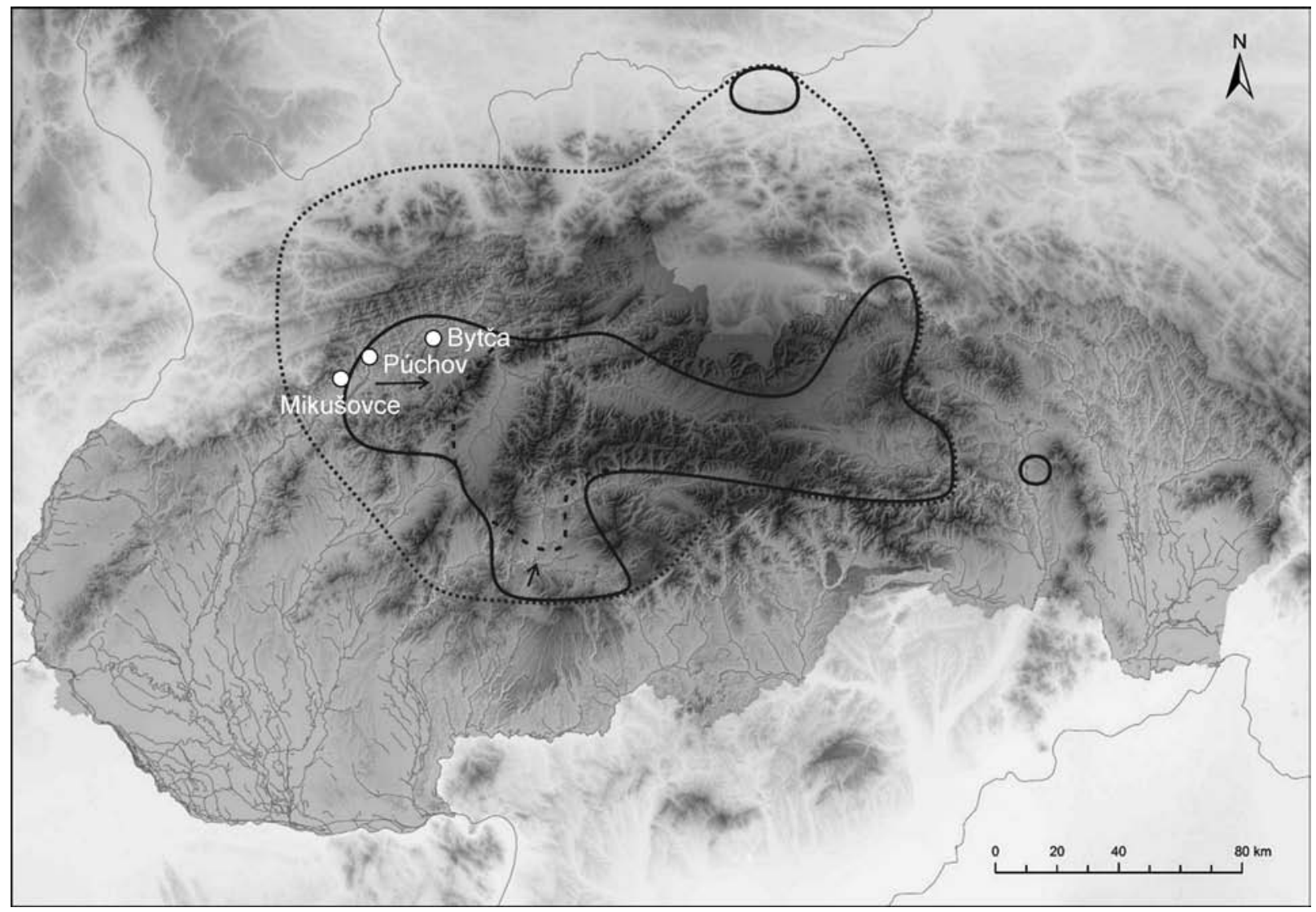

Fig. 29. A map presenting La Tène stage (dotted line) and Roman stage (broken and solid lines) of Púchov culture (according to Švihurová 2017) together with the sites with Early Roman skeletal graves.

\section{CULT PRACTICES AND BURIALS ON THE PÚCHOV CULTURE SITES}

Small hillforts with a settlement located on a slope or at the foot of a hill are characteristic habitats of the Púchov culture. These settlement patterns certainly result from the landscape features - in Western Carpathians, there are many small, steep hills located in mouths of tributary valleys in the Váh Basin but also, to a lesser extent, in the Nitra and Hron Basins as well as other regions in the Northern and Central Slovakia. Hillforts in Bytča-Hrabové and Mikušovce share all substantial features with other sites of this type. Generally, these are small fortifications located in hardly accessible but densely populated areas of the Middle Váh valley. Numerous projectiles as well large assemblages, including hoards found there, together with the lack of any traces that would suggest that the sites were used also afterwards, imply that these settlements were abruptly abandoned at the beginning of the Roman Period. Similar processes were observed on numerous other sites in the entire area dominated by the
Púchov culture, primarily in the Middle Váh valley (Pieta 2009). Undoubtedly, this phenomenon is a reflection of dramatic historical events that so significantly affected settlement in the entire Western Carpathian region and, more generally, Middle Danube Region.

In terms of extreme location, inventories and anthropological material, the graves - found and partially researched on both sites - offer new insights into the process of decline of Púchov culture fortifications. Furthermore, these unique finds contribute to understanding burial and ritual customs as well as the ethic and cultural situation during dramatic changes that took place in the $1^{\text {st }} \mathrm{C}$. CE in the vast Middle Danube Region. The author is aware that the sources are insufficient and that the number of reliably dated graves is not very large. A common feature of all these graves is ritual inhumation of bodies laid in an outstretched position with heads facing south (Bytča-Hrabové) or north (Mikušovce). However, we do not know whether the orientation results from some ritual customs or simply from the specific geographical features of the site (just outside the ramparts). 
The deceased, undoubtedly women, were buried with all metal elements of their attire and other small items (as vessels, spindle whorl, mirrors or animal bones). At least in one case (the double grave from Bytča), we are certain that the deceased died a violent death.

The records about skeletal graves from Púchov discovered by E. Hoenning at the end of the $19^{\text {th }} \mathrm{C}$. - are products of their times but still provide precious pieces of information. According to the accompanying finds, at least two of the burials should be attributed to the beginnings of the Roman Period. Also, the grave of a female with an infant resembles grave 1 from Mikušovce. Location of the graves - close to the fortifications - is consistent at both sites. Grave orientation, however, is different. Four skeletons discovered in Púchov laid along the west-east (east-west) axis. Only the last skeleton - the one without the skull - had a different orientation (Beninger 1937, 61, 62). A significant feature of the graves is animal bones, allegedly found by the skeletons. Although we cannot be certain whether these were parts of the burial inventory or rather remains of prehistoric settlement characterised by rich fauna, traces of 'meat feasts' were probably also discovered in graves 1 and 2 in Mikušovce.

The evolution of burial rites adopted by the La Tène civilisation in Central Europe is well known. Burying the deceased on both long-used and newly-established row graveyards ended at the end of the $\mathrm{C} 1$ stage that is at the turn of the $3^{\text {rd }}$ and $2^{\text {nd }} c$. BCE. We have no evidence about the burial customs in the Late La Tène Period (Pieta 2018; Repka 2015). Ritual burials on graveyards continue for some time but only in specific areas such as the Eastern Alps, Bavaria etc. In mountainous regions of Slovakia, the situation was different. Here, for a long period between the end of the Early or the beginning of the Late Iron Age until the beginnings of the medieval period, we know no graves of the local people. At the end of the prehistoric times, local traditions favoured cremation. The urnfield tradition evolved to more or less symbolic deposition of a human remains and grave inventory ('pars pro toto'). Hypothetically, based on the simplification trend of the burial rite observed on youngest Hallstatt or Early La Tène urnfields with crematory pit graves, we can assume that the process reflects world-view transformations - the renunciation of faith in the afterlife. On sites related to the Púchov culture, sometimes single human bones were uncovered in settlement layers. This common phenomenon in the La Tène Period, so far, received little interpretations (Čižmár 2000; Waldhauser 2010).
Burnt human bones found on a small hillfort in Hradec (district Prievidza) used to be cautiously interpreted as a Púchov crematory pit grave (Bialeková/Pieta 1964, 451). This interpretation, however, has not been confirmed by decades of comprehensive research performed on the other hillforts.

It is believed that people of the Púchov culture, similarly as other La Tène societies, lost their interest in worshipping their departed and their remains when they substituted the faith in the afterlife by the reincarnation concept (Pieta 1982, 191). Fire as magic connection with the afterlife and the supernatural, dominates archaeological and written testimonies about La Tène rituals. It also determines forms of offerings of artifacts, animals and people combined with ritual destruction of the offering. A specifically Western Carpathian feature are sacrificial places with deposited cremated human sacrifices (Prosné - Pietal Moravč́k 1980; Slatina nad Bebravou - Pieta 2018). Sometimes, according to the local tradition, burnt animal sacrifices and remains of unburnt human bones were deposited in sacrificial pits (Liptovská Mara - Pieta 1982, 198-201; Pieta/Stloukal 1991). So far, however, graves with ritually deposited bodies have not been known in this region. The discovery of Early Roman skeletal graves on the Váh-valley hillforts opened a new dimension on this issue.

According to the current state of the art, it seems that the major settlement changes in the Púchov culture - reflected in the horizon of destroyed hillforts with mass finds dated back to the beginnings of the Roman Period - led to a certain interruption of religious traditions, including 'fire rituals'. This process can be observed in Liptovská Mara. On the eastern terrace of the hillfort, there was an abandoned sanctuary linked with the LTD2 stage. When the fortification was rebuilt later in the B1a stage, this previously sacred place was no longer worshipped.

It seems, however, that the old cremation rituals survived. The skeletal graves from Váh-valley are chronologically consistent with a new find from Mošovce (district Turčianske Teplice) which shows the complexity of religious imagery and practices in this critical for the Púchov culture period. During a survey with a metal detector, on one of the terraces of the upper hillfort with traces of - chronologically unspecified - iron melting, fragments of the burnt and deformed bronze pan (Type Eggers 131) were found along with an intact silver fibula (probably type Almgren 11; Grasselt 1998; Voigt 1965), an incomplete bronze eye-fibula (probably A 49) and belt elements - an omega-shaped bucket and an arched fitting with rivets linked with the 


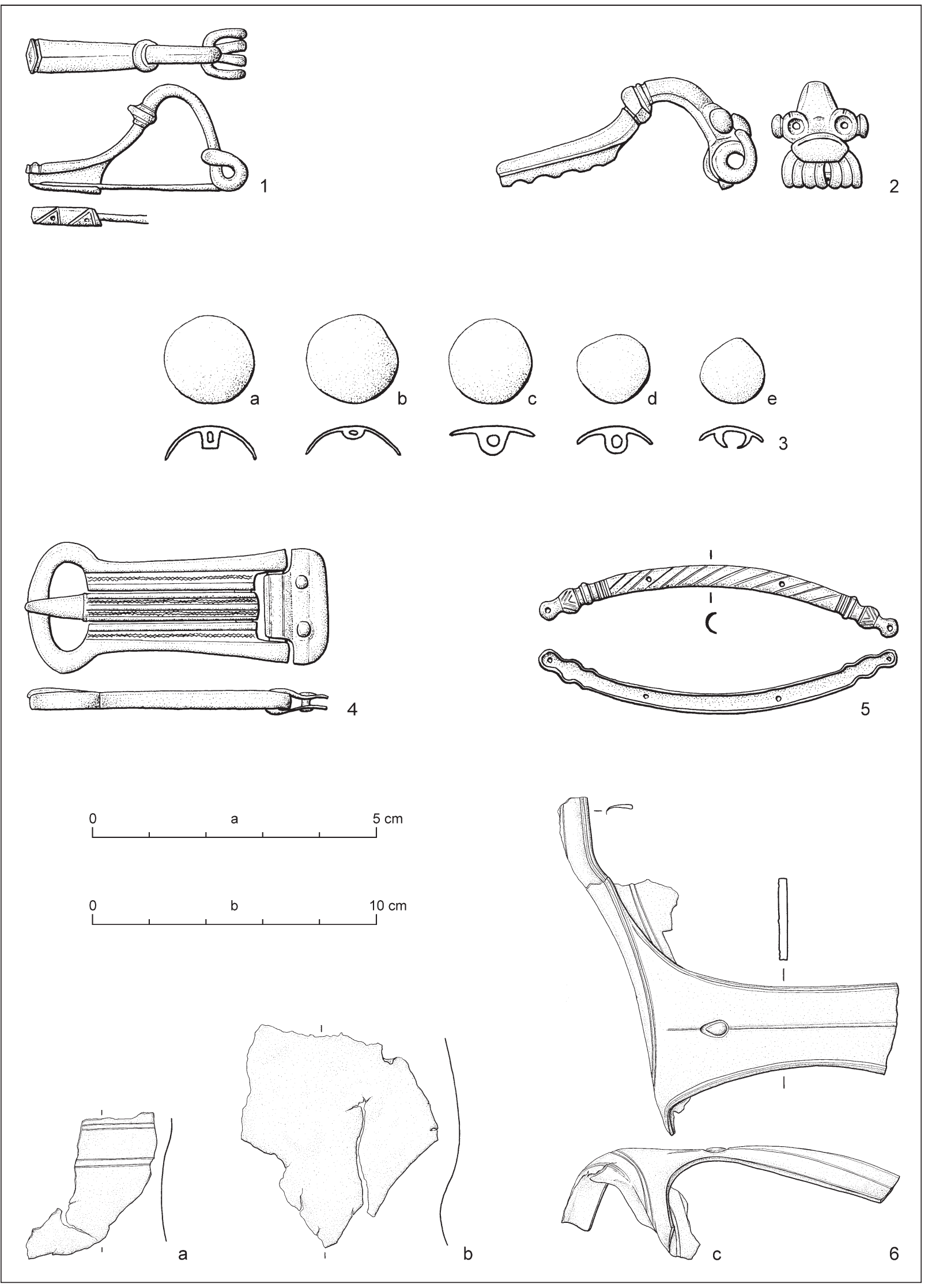

Fig. 30. Mošovce. A hoard (?) from the site Kňazov vŕšok. 1 - silver; 2-6 - bronze. Scale: a - 1-5; b -6. 
Noric-Pannonian belt (Fig. 30). The collection of artefacts was verified and reliably located, however, detailed circumstances of the discovery or the presence of any organic material that could accompany the find could not be investigated or determined. Therefore, we do not know whether it was only a single grave or a cremation-related sacrifice during which the inventory was deformed.

The complexity of sacrificial or burial (?) rituals in Northern Slovakia at the end of the La Tène Period and in the Early Roman Period is shown also by unique finds from Blatnica, district Martin (site Rémová). On an extremely steep slope in the mouth of the Gaderská valley, explorers using metal detectors found a deformed Late La Tène sword in a scabbard (Pieta 2010, fig. 126: 2), an iron spearhead with traces of melted bronze as well as bronze bracelets and human bones. Bronze brooches, belt elements and a deformed shield umbo confirm that still at the end of the Older Roman Period the site was exploited. Verifying surveys revealed fragments of another umbo, arrowheads, a Spiš type silver coin and an anthropologically examined human shoulder bone with phalanges (Pieta 2014, 147; Pieta/Švihurová, in print).

Skeletal graves from the Roman Age in NorthDanubian Barbaricum, were predominated the cremation are rare and repeatedly analysed phenomena (Bemmann/Voß 2007; Kvetánová 2008; Lichardus 1984; Pollak 1980, 11-13). Their distinctive character was explained with social position, affiliation to a different tribe or influences from the Roman provinces. Skeletal double graves - known from Bytča, Mikušovce and allegedly also from Púchov - indicate a close relationship, possibly kinship, of the deceased, which can be confirmed through DNA tests. These, together with isotope analyses, will undoubtedly contribute to answering the basic question whether the dead belonged to the locals or rather to the foreigners and where they came from. ${ }^{2}$

Skeletal graves in the milieu of Púchov culture - as already mentioned - show no affinity with strong local traditions or burial rites. There are some similarities in terms of metal inventories which, however, are rather faint. Costumes of the deceased, particularly fibulae and belts, imply that they represented the Noric-Pannonian style which - as it turns out - is a difficult to capture, highly variable 'fashion' trend adopted in the Early Roman Age rather than a purposeful export of attire or decorations in both peripheral and barbaric milieus (Rothe 2013).

\section{CONCLUSION}

According to the archaeological sources, the settlement structure in areas linked with the Púchov culture substantially changed at the beginning of the Roman Period. The process started with destructing and abandoning fortifications. Undoubtedly, this major transition reflects political turbulence resulting from massive migrations. The background of this process left a mark also in the written sources. Western parts of the Púchov culture, together with the above-described sites, were now placed between two expanding formations - the Quadi realm ruled by Vannius and their enemies, the Lugii, settled on the other side of the Carpathian crest. Conflicts between these two groups in that period were mentioned by Tacitus in his Annals (XII, 29, 30).

A part of this transformation was also a new phenomenon described in this paper - clusters of skeletal graves close by the Púchov fortifications. The deceased were buried most likely during the Tiberian-Claudian period. However, it remains uncertain whether it was before or after the hill forts were abandoned. Are these simply graves or rather ritual burials related to some unknown custom? Fatal injuries on heads of the women from Bytča-Hrabové and possibly also the arrowhead found by the skeleton from grave 3 in Mikušovce indicate that this was not an example of the usual local tradition. It seems that, similarly as in most areas related to the Late La Tène civilisation, inhumation had in the Púchov culture no tradition at all. In the neighbouring Germanic world, however, inhumation on graveyards was nothing unusual at the beginning of the Roman Period. Although, of course, crematory graves predominated.

Belt sets and fibulae or mirrors found in the graves suggest that origins of the dead should be sought somewhere in the East Alpine area. Diffusion of Noric influences to the north could be observed already in the Late La Tène settlement in Western Slovakia. The process was manifested in numerous aspects of the material culture including various types of pottery spreading from eastern Noric areas to Western Slovakia (Ćambal et al. 2014, 67; Pieta 1996, 190; 2010, 54; Pieta/Plachá 1999, 200, 201). Even more clearly, it can be observed contacts with the south according to the distribution of Pannonian and Norician coins found in areas related to the Púchov culture, particularly in its western part. As the source base grows, differences between material culture variants in

\footnotetext{
2 Osteological analysis of the material acquired from Bytča-Hrabove and Mikušovce is performed by R. Pinhasi and S. Sawyer, Universität Wien.
} 
the central (north-eastern) territories (Spiš, Liptov, Orava, Turiec) and the Middle Váh valley where our graves were discovered become more and more distinct. It seems that these regional differences date back to the end of the prehistoric times (BenedikoválPieta, in print). Southern influences from the opposite Danube bank only highlighted the distinction.

At the beginning of the Roman Period, the Noric-Pannonian 'style' - manifested in attractive female costume accessories - reached vast areas of the Danube Barbaricum, including the Púchov culture. This is also a potential source not only of the inhumation rite but also of the migrants belonging to a different cultural formation. They could be 'heralds' of the new colonisation wave that migrated through the lands settled by weakened Celtic groups in the western parts of the Púchov culture. This new expansion possibly interrupted or prevented the arrival of the Quadi in Slovakia. Nowadays, such questions - when biological material is sufficient - can be efficiently answered with prepared DNA and isotopic analyses.

Regardless of the origins of the individuals buried on the slopes outside the hillfort fortifications, explaining this phenomenon we are confronted with an important question: whether the deceased were representatives of local people (possibly killed in some battles) or they were sacrificed before or after the conflict to protect the society? The graves analysed in this paper - as a unique form of human sacrifices - could serve ritual protection of defending communities and also a magical obstacle for those who attempted to capture the fortifications. On the other hand, it is possible that the sacrifice was made by the invaders and the deceased were members of the defeated society. In the Celtic world, in case of imminent danger, human beings - as the most valuable - were sacrificed instead of animals. This phenomenon is confirmed in several ancient written sources (Caesar BG, VI: 16). Human sacrifices in the face of danger are also confirmed in the Roman history (e.g. when Hannibal threatened Rome: Livius, XXII: 57). Archaeological traces of similar rituals are nothing exceptional even in the Middle Danube Basin, including Púchov culture sacrificial sites. Forms of depositing human sacrifices were variable and certainly were related to practices devoted to specific deities. However, in the secular spheres - such as the graves on the Púchov culture hillforts - these were certainly exceptional situations, sacrifices to save the community of faithful from some imminent danger or to secure its prosperity.

\section{LITERATURE}

Adler 1976 - H. Adler: Kaiserzeitliche Funde aus Baumgarten an der March. Mitteilungen der Antropologischen Gesellschaft in Wien 16, 1976, 3-16.

Andrzejowski 1991 - J. Andrzejowski: Okucia rogów do picia z młodszego okresu przedrzynskiego i okresu wpływów rzymskich w Europie Środkowej i Północnej (Próba klasyfikacji i analizy chronologiczno-terytorialnej). Materialy Starożytne i Wczesnośredniowieczne 6, 1991, 7-120.

Andrzejowski 2002 - J. Andrzejowski: Die Trinkhornbeschläge. In: J. Peška/J. Tejral (Hrsg.): Das germanische Königsgrab von Mušov in Mähren 2. Mainz 2002, 311-328.

Aßkamp/Rudnick 2007 - R. Aßkamp/B. Rudnick: Römische Bleifunde aus Haltern. In: W. Meltzer/T. Capelle (Hrsg.): Bleibergbau und Bleiverarbeitung während der römischen Kaiserzeit im rechtsrheinischen Barbaricum. Soester Beiträge zur Archäologie. Soest 2007, 33-40.

Bataille 2001 - G. Bataille: Les agrafes de ceinturon du sanctuaire de la Villeneuve-au-Catelot (Aube). Archäologisches Korrespondenzblatt 31, 2001, 443-460.

Bazovský 2003 - I. Bazovský: Dve bronzové spony z Blatnice. Zborník SNM 97. Archeológia 13, 2003, 185, 186.

Bazovský 2014 - I. Bazovský: Bronzové predmety z Križovian nad Dudváhom (okr. Trnava, JZ Slovensko). In: J. Čižmářová/N. Venclová/G. Březinová (ed.): Moravské křižovatky. Střední Podunají mezi pravěkem a historií. Brno 2014, 615-620.
Bazovský 2017 - I. Bazovský: K otázke výskytu noricko-panónskych spôn s krídelkami severne od stredného toku Dunaja. In: Droberjar/Komoróczy 2017, 157-161.

Beckmann 1969 - Ch. Beckmann: Metallfingerringe der römischen Kaiserzeit im Freien Gemanien. Saalburg Jahrbuch 26, 1969, 5-106.

Beckmann 1981 - Ch. Beckmann: Arm- und Halsringe aus den Kastellen Feldberg. Saalburg und Zugmantel. Saalburg Jahrbuch 37, 1981, 10-22.

Bemmann 1999 - J. Bemmann: Norisch-pannonische Trachtbestandteile aus Mitteldeutschland. Arbeits- und Forschungsberichte zur sächsischen Bodendenkmalpflege 41, 1999, 151-174.

Bemmann/Voß2007 - J. Bemmann/H-U. Voß: Anmerkungen zur Körpergrabsitte in den Regionen zwischen Rhein und Oder vom 1. bis zur Mitte des 5. Jahrhunderts n. Chr. In: A. Faber/P. Fasold/M. Struck/M. Witteyer (Hrsg.): Körpergräber des 1.-3. Jahrhunderts in der römischen Welt. Schriften des Archäologischen Museums Frankfurt 21. Frankfurt am Main 2007, 153-183.

Benediková 2017 - L. Benediková: Kulturkontakte des slowakischen Teils der Westkarpaten während der Hallstattzeit. In: E. Miroššayová/Ch. Pare/S. Stegmann-Rajtár (Hrsg.): Das nördliche Karpatenbecken in der Hallstattzeit. Wirtschaft, Handel und Kommunikation in früheisenzeitlichen Gesellschaften zwischen Ostalpen und Westpannonien. Archaeolingua 38. Budapest 2017, 335-381. 
Benediková/Pieta 2018a - L. Benediková/K. Pieta: Využitie krajiny stredného Liptova v praveku a včasnej dobe dejinnej. Študijné zvesti Aú SAV 63, 2018, 147-193.

Benediková/Pieta 2018b - L. Benediková/K. Pieta: Lužické hradisko s následným laténskym osídlením v Soblahove (okres Trenčín). In: L. Benediková/M. Horňák (eds.): Sídla, artefakty a čas... Zborník štúdií o dobe bronzovej a dobe halštatskej $k$ 75. narodeninám Ladislava Veliačika. Nitra Vrútky 2018, 37-54.

Benediková/Pieta, in print - L. Benediková/K. Pieta: Early and Middle La Tène Period in the Slovak Carpathians. In: Unité et diversité du monde celtique. $42^{e}$ colloque international. Prague 2019, in print.

Beninger 1937 - E. Beninger: Die germanischen Bodenfunde in der Slowakei. Reichenau/Leipzig 1937.

Bialeková/Pieta 1964 - D. Bialeková/K. Pieta: Zistovací výskum v Hradci, okres Prievidza. Slovenská archeológia 12, 1964, 447-461.

Blankenfeldt 2015 - R. Blankenfeldt: Das Thorsberger Moor. Band 2. Die persönlichen Ausrüstungen. Schleswig 2015.

Bockius 1990 - R. Bockius: Eingefriedete endlatènezeitliche Gräber bei Thür, Kr. Mayen-Koblenz. In: H.-H. Wegner (Hrsg.): Berichte zur Archäologie an Mittelrhein und Mosel 2. Trierer Zeitschrift 12. Trier 1990, 145-168.

Bockius/Łuczkiewicz 2004 - R. Bockius/P. Łuczkiewicz: Kelten und Germanen im 2.-1. Jahrhundert vor Christus. Römisch-Germanisches Zentralmuseum. Monographien 58. Mainz 2004.

Böhme-Schönberger 1998 - A. Böhme-Schönberger: Die provinzialrömischen Fibeln bei Almgren. 100 Jahre Fibelformen nach Oscar Almgren. Forschungen zur Archäologie im Land Brandenburg 5. Wünsdorf 1998, 351-366.

Budinský-Krička/Lamiová-Schmiedlová 1990 - V. Budinský-Krička/M. Lamiová-Schmiedlová: A late $1^{\text {st }}$ century B. C. $-2^{\text {nd }}$ Century A. D. Cemetery at Zemplín. Slovenská archeológia 38, 1990, 245-354.

Bujna 2005 - J. Bujna: Kruhový šperk z laténskych ženských hrobov na Slovensku. Nitra 2005.

Caesar BG - G. I. Caesar: Commentarii de bello gallico. Zápisky o válce galské. In: G. I. Caesar: Válečné paměti. Antická knihovna 16. Praha 1972, 231-263.

v. Carnap-Bornheim 2002 - C. von Carnap-Bornheim: Der Trachtschmuck, die Gürtel und das Gürtelzubehöhr. In: J. Peška/J. Tejral (Hrsg.): Das germanische Fürstengrab von Mušov in Mähren. Germanisches Zentralmuseum Monographien 55/1, 2. Mainz 2002, 189-305, 537-557.

Czarnecka 1989 - K. Czarnecka: Ein Ring aus Roggendorf un Niederösterreich und seine Parallelen im Barbaricum. Fundberichte aus Österreich 27, 1988, 1989, 11-17.

Čambal 2017 - R. Čambal: Spony z neskorej doby laténskej z územia juhozápadného Slovenska s dôrazom na zázemie Bratislavského oppida. In: Droberjar/Komoróczy 2017, 87-106.

Čambal/Budaj 2009 - R. Čambal/M. Budaj: Keltské tetradrachmy z Pezinka a Bratislavy-Rače. Zborník SNM 103. Archeológia 19, 2009, 197-208.

Čambal et al. 2014 - R. Čambal/I. Bazovský/G. Březinová/ B. Kovár/M. Karwowski: Problematika hrncov s tzv. „kyjovitým“ okrajom zo záveru neskorej doby laténskej v stredodunajskom priestore. In: B. Komoróczy (ed.): Sociální diferenciace barbarských komunit ve světle nových hrobových, sídlištních a sběrových nálezů (Archeologie barbarů 2011). Spisy AÚ AV ĆR 44. Brno 2014, $63-77$.
Čižmář 2000 - M. Čižmář: Nálezy lidských kostína moravských sídlištích doby laténské. Památky Archeologické. Supplementum 13. Brno 2000, 81-91.

Danielisová/Militký 2014 - A. Danielisová/J. Militký: Pozdně laténské spony z oppida Třísov, získané povrchovou prospekcí v letech 2008-2013. Archeologické rozhledy 66, 2014, 40-66.

Deimel 1987 - M. Deimel: Die Bronze-Kleinfunde vom Magdalensberg. Archäologische Forschungen zu den Grabungen auf dem Magdalensberg 9. Klagenfurt 1987.

Demetz 1999 - S. Demetz: Typen der Spätlatène- und frühen römischen Kaiserzeit in den Alpenländern. Rahden/Westf. 1999.

Dizdar/Božič 2010 - M. Dizdar/D. Božič: O nekim oblicima fibula s kasnolatenskog naselja Virovitica - Kiškorija sjever. On some shapes of fibulae from the Late La Tène settlement of Virovitica - Kiškorija sjever. Prilozi Instituta za Arheologiju u Zagrebu 27, 2010, 145-160.

Drescher 1995 - H. Drescher: Die Verbreitung von Buntmetall auf der Heuneburg. In: E. Gersbach (Hrsg.): Baubefunde der Perioden IVc-IVa der Heuneburg. Heuneburgstudien IX. Römisch-germanische Forschungen 53. Mainz 1995, 255-364.

Droberjar 1999 - E. Droberjar: Dořichov-Pičhora. Ein Brandgräberfeld der älteren römischen Kaiserzeit in Böhmen (Ein Beitrag zur Kenntnis des Marbod-Reiches). Fontes Archaeologici Pragenses 23. Praha 1999.

Droberjar 2006 - E. Droberjar: Plaňanská skupina grossromstedtskej kultury. K chronologii germánských nálezů. In: E. Droberjar/M. Lutovský (eds.): Archeologie barbarů 2005. Praha 2006, 11-90.

Droberjar/Komoróczy 2017 - E. Droberjar/B. Komoróczy (eds.): Ǩimské a germánské spony ve střední Evropě (Archeologie barbarů 2012). Spisy AÚ AV ČR 53. Brno 2017.

v. Endert 1991 - D. van Endert: Die Bronzefunde aus dem Oppidum von Manching. Stuttgart 1991.

Garbsch 1965 - J. Garbsch: Die Norisch-pannonische Frauentracht im 1. und 2. Jahrhundert. Münchner Beiträge zur Vor- und Frühgeschichte 11. München 1965.

Garbsch 1985 - J. Garbsch: Die norisch-pannonische Tracht. In: H. Temporini (Hrsg.): Aufstieg und Niedergang der Romischen Welt II. Principat 12/3. Berlin - New York 1985, 546-577.

Glunz 1997 - B. Glunz: Studien zu den Fibeln aus dem Gräberfeld von Hallstatt, Oberösterreich. Linzer Archäologische Forschungen 25. Linz 1997.

Glüsing 1968 - P. Glüsing: Studien zur Chronologie und Trachtgeschichte der Spätlatèzeit und der frühen römischen Kaiserzeit. Kiel 1968.

Grasselt 1998 - Th. Grasselt: Die Fibelformem Almgren I, 10-14. Geschichte und Stand der Forschung. In: J. Kunow (Hrsg.): 100 Jahre Fibelformen nach Oscar Almgren. Forschungen zur Archäologie im Land Brandenburg 5. Wünsdorf 1998, 29-38.

Hoenning O'Caroll/Halaša 1903 - E. Hoenning O'Caroll/ A. Halaša: Púchovské starožitnosti. Sborník muzeálnej slovenskej spoločnosti 8, 1903, 1-23.

Husár 2014 - M. Husár: Žrd’ovo-bodné zbrane včasného stredoveku v Karpatskej kotline. 1. diel. Typológia a jej vyhodnotenie. Nitra 2014.

Ilkjaer 1993 - J. Ilkjaer: Illerup Ådal 3. Die Gürtel. Bestandteile und Zubehör. Ârhus 1993.

Istvánovics/Kulcsár 2017 - E. Istvánovics/V. Kulcsár: Once more about Sarmatian and Germanic connections - 
from a new point of wiew. In: B. Valentin Eriksen/ A. Abegg-Wigg/R. Bleile/U. Ickerodt (Hrsg.): Interaktion ohne Grenzen. Beispiele archäologischer Forschungen am Beginn des 21. Jahrhunderts. Schleswig 2017, 387-397.

Jakab 2011 - J. Jakab: Kostry zo ženského dvojhrobu púchovskej kultúry v Bytči. AVANS 2008, 2011, 116-118.

Ježišková/Pieta 2019 - L. Ježišková/K. Pieta: Neskorolaténske hradisko v Stupnom. Študijné zvesti Aú SAV 65, 2019, 71-88.

Karwowski/Militký 2011 - M. Karwowski/J. Militký: The Oberleiserberg types in the context of Taurisci influeces. In: M. Guštin/M. Jevtić (eds.): The Eastern Celts. The Communities between the Alps and the Black Sea. KoperBeograd 2011, 131-136.

Keller 1984 - E. Keller: Die frühkaiserzeitlichen Körpergräber von Heimstetten. Veröffentlichungen der Kommission zur Erforschung des spätrömischen Raetien der Bayerischen Akademie der Wissenschaften. München 1984.

Kolník 1977 - T. Kolník: Anfänge der germanischen Besiedlung in der Südwestslowakei und das Regnum Vannianum. In: Symposium Ausklang der Latène-Zivilisation und Anfänge der germanischen Besiedlung im mittleren Donaugebiet. Bratislava 1977, 143-171.

Kolník 1980 - T. Kolník: Römerzeitliche Gräberfelder in der Slowakei. Archaeologica Slovaca. Fontes 14. Bratislava 1980.

Kolníková/Kolník 2004 - E. Kolníková/T. Kolník: Mince a spony - depot z neskorolaténskeho hradiska Rochovica pri Žiline (numizmaticko-archeologické súvislosti). Slovenská archeológia 52, 2004, 1-34.

Kotigoroško 1989 - V. G. Kotigoroško: Gorodišča rubeža našej ery v verchnem Potisje. Slovenská archeológia 37, 1989, 21-67.

Kunow 1998 -J. Kunow: Hauptserie der Augenfibeln: Gruppe III, fig. 45-54. In: J. Kunow (Hrsg.): 100 Jahre Fibelfgormen nach Oscar Almgren. Internationale Arbeitstagung 25-28. Mai 1997, Kleinmachnow, Land Brandenburg. Forschungen zur Archäologie im Land Brandenburg 5. Wünsdorf 2002, 93-118.

Kvetánová 2006 - I. Kvetánová: Noricko-panónske súčasti odevu v germánskych hroboch zo severnej časti stredného Podunajska. In: E. Droberjar/M. Lutovský (eds.): Archeologie barbaru 2005. Praha 2006, 379-404.

Kvetánová 2008 - I. Kvetánová: Kroj a šperk stredodunajských Germánov v 1.-4. stor. po Kr. (na základe hrobových nálezov). Dizertačná práca. Archeologický ústav SAV. Nitra 2008. Unpublished.

Lichardus 1984 - J. Lichardus: Körpergräber der frühen Kaiserzeit im Gebiet der südlichen Elbgermanen. Saarbrücker Beiträge zur Altertumskunde 43. Bonn 1984.

Livius - T. Livius: Ab urbe condita. Livius, Dějiny IV. Antická knihovna 21. Praha 1973.

Łuczkiewicz 2009 - P. Łuczkiewicz: Norisch-pannonische Doppelknopffibeln im Osten des Barbaricums. Ethnogrpahisch-Archäologische Zeitschrift 50/3, 2009, 409-423.

Madyda-Legutko 1987 - R. Madyda-Legutko: Die Gürtelschnallen der römischen Kaiserzeit und der frühen Völkerwanderungszeit im mittelauropäischen Barbaricum. BAR International Series 360. Oxford 1987.

Madyda-Legutko 1990 - R. Madyda-Legutko: Gürtelhaken der frührömischen Kaiserzeit im Gebiet des mitteleuropäischen Barbarikum. Przeglad Archeologiczny 37, 1990, 157-180.
Mansfeld 1973 - G. Mansfeld: Die Fibeln der Heuneburg 1950-1970. Ein Beitrag zur Geschichte der Späthallstattfibel. Römisch-germanische Forschungen 33. Heuneburg Studien II. Berlin 1973.

Mazuch 2003 - M. Mazuch: Fischereigerät aus Mikulčice und die Frage des Fischanteils an der Ernährung der Bewohner des Burgwalls. In: L. Poláček (Hrsg.): Studien zum Burgwall von Mikulčice. Band 5. Brno 2003, 355-399.

Niezabitowska-Wiśniewska 2012 - B. Niezabitowska-Wiśniewska: Distribution of Roman Mirrors in Scandinavia and in the Crimea - the Diferences ans Similarities (against the Distribution of Roman Mirrors in the European Barbaricum). In: P. Łuczkiewicz (ed.): The Younger Generation. Akten des ersten Lublin-Berliner Doktorandenkolloquiums am 9.-10. 6. 2010 in Lublin. Lublin 2012, 181-342.

Petrovský-Šichman 1965 - A. Petrovský-Šichman: Severozápadné Slovensko v dobe laténskej a rímskej. Vlastivedný zborník Považia 7, 1965, 53-129.

Pieta 1982 - K. Pieta: Die Púchov-Kultur. Archaeologica Slovaca Monographiae. Studia 1. Nitra 1982.

Pieta 1996 - K. Pieta: Der römische Import der Spätlatènezeit in der Slowakei. Arheološki Vestnik 47, 1996, 183-195.

Pieta 1997 - K. Pieta: Die frühen norisch-pannonischen Handelsbeziehungen mit dem nördlichen Mitteldonaugebiet. In: Z. Měchurová/J. Čižmářová (eds.): Peregrinatio Gothica. Jantárová stezka. Supplementum ad Acta Musei Moraviae Scientiae Sociales 82. Brno 1997, 39-56.

Pieta 2000 - K. Pieta: Die Siedlung Liptovská Mara II und die Anfänge der Einflüsse der Latène-Kultur im Westkarpatenraum. Slovenská archeológia 48, 2000, 315-346.

Pieta 2006 - K. Pieta: Ein junglatènezeitlicher Stieranhänger aus Udiča/Slowakei. In: W. R. Teegen/R. Cordie/ O. Dörrer/S. Rieckhoff-Hesse/H. Steuer (Hrsg.): Studien zur Lebenswelt der Eisenzeit. Reallexikon germanischer Altertumskunde 53. Berlin - New York 2006, 133-147.

Pieta 2008 - K. Pieta: Keltské osídlenie Slovenska. Archaeologica Slovaca Monographiae. Studia 11. Nitra 2008.

Pieta 2009 - K. Pieta: Untergang der Burgwälle der Púchov-Kultur. In: V. Salač/J. Bemmann (Hrsg.): Mittelauropa in der Zeit Marbods. Praha - Bonn 2009, 273-287.

Pieta 2010 - K. Pieta: Die keltische Besiedlung der Slowakei. Jüngere Latènezeit. Archaeologica Slovaca Monographiae. Studia 12. Nitra 2010

Pieta 2012 - K. Pieta: Bronzové náramky s vývalkami z konca doby halštatskej a začiatku doby laténskej na severnom Slovensku. In: R. Kujovský/V: Mitáš (eds.): Václav Furmánek a doba bronzová. Zborník k sedemdesiatym narodeninám. Archaeologica Slovaca Monographiae. Communicationes 13. Nitra 2012, 315-324.

Pieta 2014 - K. Pieta: Hradiská vo Folkušovej-Necpaloch a Blatnici. Juhovýchodné prvky v púchovskej kultúre. Slovenská archeológia 62, 2014, 125-165.

Pieta 2017 - K. Pieta: Včasnostredoveké mocenské centrum Bojná - výskumy v rokoch 2007-2013. In: K. Pieta/ Z. Robak (eds.): Bojná 2. Nové výsledky výskumov včasnostredovekých hradísk. Archaeologica Slovaca Monographiae. Fontes 22. Nitra 2017, 11-45.

Pieta 2018 - K. Pieta: Ein mittellatènezeitlicher Brandopferplatz in Slatina nad Bebravou (Slowakei). Študijné zvesti AÚ SAV 64, 2018, 89-113.

Pieta/Plachá 1999 - K. Pieta/V. Plachá: Die ersten Römer im nördlichen Mitteldonauraum im Lichte der neuen Grabungen in Devín. In: Th. Fischer/G. Precht/J. Tejral 
(Hrsg.): Germanen beiderseits des spätantiken Limes. KölnBrno 1999, 179-205.

Pieta/Stloukal 1991 - K. Pieta/M. Stloukal: L’udské pozostatky z neskorolaténskeho obetiska v Liptovskej Mare. Antropologie 156/1-4, 1991, 49-66.

Pieta/Švihurová, in print-K. Pieta/M. Švihurová: Influence of the Przeworsk culture in the Púchov culture milieu. In: Movement and stabilization. Przeworsk culture in the upper Tisa river basin in the Roman period. Kraków, in print.

Pollak 1980 - M. Pollak: Die germanischen Bodenfunde des 1.-4. Jahrhunderts $n$. Chr. im nördlichen Niederösterreich. Wien 1980.

Pöllath 2002 - R. Pöllath: Karolingerzeitliche Gräberfelder. Eine archäologisch-historische Interpretation mit der Vorlage der Ausgrabungen von K. Schwartz in Weismain und Thurnau-Alladorf. München 2002.

Prohászka 2017 - P. Prohászka: Észrevételek a Púchov-kultúra Kr. U. 1. századi temetkezéseihez. Bemerkungen zu den Bestattungen der Púchov-Kultur im 1. Jahrhundert n. Chr. In: J. Kisné Cseh (szerk.): Korszakok és Birodalmak Határán - Kelták a Kárpát-medencében. Tatabányai Múzeum Tudományos Füzetek 12. Tatabánya 2017, 133-146.

Redlich 1977 - C. Redlich: Zur Trinkhornsitte bei den Germanen der älteren Kaiserzeit. Prähistorische Zeitschrift 52, 1977, 61-102.

Repka 2015 - D. Repka: Odraz historických udalostí staršej doby laténskej v hrobovej výbave na keltských pohrebiskách v Karpatskej kotline. Nitra 2015.

Riha 1994 - E. Riha: Die römischen Fibeln aus Augst und Kaiseraugst. Die Neufunde seit 1975. Forschungen in Augst 18. Augst 1994.

Rothe 2013 - U. Rothe: Die norisch-pannonische Tracht: gab es wirklich? In: G. Grabherr/B. Kainrath/Th. Schierl (Hrsg.): Verwandte in der Fremde. Fibeln und Bestandteile der Bekleidung als Mittel zur Rekonstruktion von interregionalen Austausch und zur Abgrenzung von Gruppen vom Angreifern Roms während des 1. Punischen Krieges bis zum Ende des weströmischen Reiches. IKARUS. Innsbrucker klassisch-archäologische Universitätsschriften 8. Innsbruck 2013, 34-48.

Rustoiu 1997 - A. Rustoiu: Fibulele din Dacia preromană (sec II $\hat{\imath}$. e. n. $-I$ e. n.). Bibliotheca Thracologica 23. Institutul Român de Tracologie. Bucureşti 1997.

Salač 2010 - V. Salač: K rozsahu a významu tzv. keltského dědictví v hospodářství starší doby římské v Čechách a ve střední Evropě. In: J. Beljak/G. Březinová/V. Varsik (eds.): Archeológia barbarov 2009. Hospodárstvo Germánov. Nitra 2010, 351-370.

Manuscript accepted 14. 10. 2019

Translated by Magdalena Adamus
Schuster 2010 - J. Schuster: Lübsow. Älterkaiserzeitliche Fürstengräber im nördlichen Mitteleuropa. Bonner Beiträge zur Vor- und Frühgeschichtlichen Archäologie 12. Bonn 2010.

Sedlmayer 2009 - H. Sedlmayer: Die Fibeln von Magdalensberg. Funde der Grabungsjahre 1948-2002 und Altfunde des 19. Jahrhunderts. Archäologische Forschungen zu den Grabungen auf dem Magdalensberg 16. Klagenfurt am Wörthersee 2009.

Stöllner 2002 - Th. Stöllner: Die Hallstattzeit und der Beginn der Latènezeit im Inn-Salzach-Raum. Archäologie in Salzburg 3/1. Salzburg 2002.

Štolcová 2011 - T. Štolcová: Bytča-Hrabové. Výskumná správa. Archeologický ústav SAV. Nitra 2011. Unpublished.

Švihurová 2017 - M. Švihurová: Osídlenie severného Slovenska v staršej dobe rímskej na základe sídliska Liptovská Mara III. Dizertačná práca. Archeologický ústav SAV. Nitra 2017. Unpublished.

Tacitus, Annales - C. Tacitus: Ab excessu divi Augusti. Tacitus, Letopisy. Antická knihovna 27. Praha 1975.

Tempelmann-Mączyńska 1985-M. Tempelmann-Mączyńska: Die Perlen der römischen Kaiserzeit und der frühen Phase der Völkerwanderungszeit im mitteleuropäischen Barbaricum. Römisch-germanische Forschungen 43. Mainz 1985.

Urban 2006 - O. H. Urban: Ausgewählte latènezeitliche Eisendepotfunde aus Österreich. In: G. Bataille/J.-P. Guillaumet (eds.): Les depôts métalliques au second âge du Fer en Europe tempére. Collection Bibracte 11. Glux-en-Glenne 2006, 83-99.

Voigt 1965 - Th. Voigt: Zur Neugliederung der eingliedrigen Armbrustfibel mit breitem Fußteil (Almgren Gruppe I, 10-14). Jahrbuch der Bodendenkmalpflege. Mecklenburg 1964, 1965, 175-225.

Waldhauser 2010 - J. Waldhauser: Lidské osteologické pozůstatky v sídelních strukturách z období HaD-LD v Čechách a na Moravě. In: J. Bouzek (ed.): Hrobky, pohřby a lidské pozůstatky na pravěkých a středověkých sídlištích. Živá archeologie. Supplementum 3. Hradec Králové 2010, 151-156.

Zajacová/Pivovarová 2015 - B. Zajacová/Z. Benkovsky-Pivovarová: Archeologické prieskumy a výskumy v katastri obce Mikušovce (okr. Ilava). In: O. Oždáni (ed.): Popolnicové polia a doba halštatská. Archaeologica Slovaca Monographiae. Communicationes 17. Nitra 2015, 253-262.

Zeman 2017 - T. Zeman: Střední Pomoraví v době ř́mské. Svědectví povrchové prospekce. Archaeologica Olomoucensia II. Olomouc 2017.

PhDr. Karol Pieta, DrSc.

Archeologický ústav SAV

Akademická 2

SK - 94921 Nitra

karol.pieta@savba.sk 


\title{
Pohreby z včasnej doby rímskej v oblasti púchovskej kultúry: pochovaní domáci alebo obetovaní cudzinci?
}

\author{
Ka rol Pieta
}

\author{
SÚHRN
}

\begin{abstract}
Spôsob pochovávania domáceho obyvatel'stva doby laténskej v západokarpatskej horskej oblasti nie je známy. L'udské pozostatky sa v tejto dobe nachádzajú v podobe ojedinelých nespálených kostí v sídliskových vrstvách alebo ako súčast’ obetných miest, ktoré sa objavujú na konci staršieho stupňa strednej doby laténskej (Pieta 2010, 317-324; 2018). Objav kostrových hrobov na neskorolaténskych opevneniach púchovskej kultúry na strednom Považí bol prekvapením a impulzom k prehodnoteniu funerálnych zvyklostí i kultúrno-etnických pomerov v tejto oblasti na prelome doby laténskej a rímskej. Výskumy v Bytči-Hrabovom a v Mikušovciach umožnili nový pohlad na túto problematiku a viedli aj $\mathrm{k}$ prehodnoteniu starších nálezov tohto typu.
\end{abstract}

\section{Bytča-Hrabové}

Na strmom svahu poniže valu neskorolaténskeho hradiska Hlavina ( 575 m n. m. Bytča-Hrabové, okres Bytča) sa v roku 2008 zistili l’udské kosti (obr. 1; 2). Odborne sa tu preskúmali a zdokumentovali dve vedl'a seba ležiace kostry vo vystretej polohe, orientované hlavami na juh. Išlo nepochybne o dvojhrob (obr. 3-5). Miestami porušenú polohu jednotlivých súčastí hrobovej výbavy sa podarilo spolahlivo zrekonštruovat'. Kostra 1 mala na pleciach spony, na hrdle železný kruh, ovinutý cínovým drôtom a na pravej ruke jeden a na prstoch lavej ruky štyri bronzové prstene. Odev doplńal kožený opasok s ozdobnými pukličkami a kovaniami ukončený prelamovanou bronzovou záponou. Za hlavou sa našlo kovové zrkadlo (obr. 6). Skelet patril 30- až 40-ročnej žene gracilnej stavby. V oblasti čelovej kosti, na l’avom spánku a na temene lebky boli stopy po úderoch tupým predmetom z perimortálneho obdobia (Jakab 2011). Kostra 2 mala na oboch ramenách spony a v oblasti pása železnú záponu, za hlavou čast' kovového zrkadla (obr. 7). Medzi hlavami oboch jedincov ležala roztlačená nádobka a o niečo nižšie v blízkosti hrudníka kostry 2 sa našiel praslen. Kostra 2 patrila 20- až 30-ročnej žene gracilnej stavby. Na lebke sa zachovali záseky z perimortálneho obdobia, nepochybne ako dôsledok úderov ostrým predmetom, azda sekerou (Jakab 2011).

Počas prieskumov sa na hradisku našli dva hromadné nálezy (obr. 8; 9), množstvo artefaktov i železná troska ako doklad remeselnej výroby. Podla nájdených spôn bolo hradisko využívané od konca stredolaténskeho obdobia a zaniklo na začiatku doby rímskej (obr. 10). Do tohto obdobia patrí aj hromadný nález 2 (garnitúra opaska) i opísaný dvojhrob. K charakteristikám násilného zániku hradísk na severnom Slovensku patrí množstvo projektilov, najmä hroty šípov (obr. 13; 14) a riečnych kameňov do praku. Hroty šípov sa na lokalite aj vyrábali (obr. 15).

\section{Mikušovce}

Hradisko Mikušovce, okres Ilava, Malý hrádok (500 m n. m.) patrí k typickým malým opevneniam púchovskej kultúry (obr. 16; 17). Na strmom zalesnenom svahu pod valovým opevnením sa v roku 2001 našiel kostrový hrob 3, ktorý bol neodborne preskúmaný a zdokumentovaný. V rokoch 2011-2012 sa v jeho blízkosti odborne odkryli d’alšie hroby označené ako hrob 1 a hrob 2 (obr. 18; 19). V hrobe 1 ležala vo vystretej polohe v smere sever - juh kostra bližšie neurčeného jedinca vo veku adultus I spolu s kostami novorodenca (infans I). Súčastou výbavy boli bronzové spony na oboch pleciach, šest’ korálikov s transparentného skla so zlatou fóliou, tri bronzové prstene a železná zápona opaska (obr. 20). Ned’aleko nôh tohto jedinca bola hlava rovnako orientovaného hrobu 2. Bola to žena vo veku adultus I nízkeho vzrastu $(148 \mathrm{~cm})$. Jej výbavu tvorili dve spony, prsteň a zápona opaska (obr. 21). V hrobe 3 podla dochovaných fotografií (obr. 22) ležal dospelý jedinec vo vystretej polohe, so sponami na pleciach a pod bradou. $V$ oblasti pása sa našli súčasti bronzovej noricko-panónskej opaskovej garnitúry, ale aj sklená perla a pseudofiligránový bronzový kruhový závesok. Pri stehennej kosti ležal hrot šípu (obr. 23).

Lokalita bola osídlená už v eneolite a koncom doby halštatskej. Laténske a včasnorímske nálezy, získané pri prieskumoch a sondážach predstavujú vel'kú väčšinu inventára náleziska (obr. 24; 25). Na lokalite sa podla rôznych informácií ojedinele našli dve mince. Razba vel'kobystereckého typu bola nájdená v južnej časti opevnenia, minca typu Divinka v spodnej časti východného svahu. $\mathrm{V}$ jeho strednej časti sa našiel depot deviatich vel'kobystereckých mincí. Významnú čast nálezov predstavujú početné riečne kamene a hroty šípov (obr. 26).

\section{Uloženie a inventár hrobov}

Na náleziskách v Bytči-Hrabovom a v Mikušovciach boli zistené dva samostatné, ale bezprostredne pri sebe ležiace hroby a dva hroby s dvomi jedincami. Vo všetkých prípadoch išlo o kostrové hroby vo vystretej polohe a okrem dietata neurčeného pohlavia z hrobu Mikušovce 1 to boli výlučne ženy. Na oboch lokalitách boli hroby umiestnené na strmom svahu pred opevnením. Zosnulé mali pri sebe najmä kovové a sklené súčasti kroja, ktorého základom bola dvojica spínadiel na pleciach reprezentovaných noricko-panónskymi sponami. Typy A 67 a A 236 patria k charakteristickým nálezom zánikového horizontu hradísk púchovskej kultúry (obr. 28: 1-3, 7-18). V hroboch Bytča 1 a 2 s uložením štyridsatročnej a dvadsat'- až tridsat'ročnej 
ženy, ako aj v hrobe Mikušovce 3 sa našli typy A 67b1, časovo spadajúce do včasnotibériovskej doby (Demetz 1999, 135). Aj krídelkové spony z hrobu Mikušovce 3 patria k skorým variantom A 238b (podl'a Garbscha), resp. $238 b 2$ (podla Demetza). Vzniku, rozšíreniu a datovaniu týchto spínadiel sa venovala značná pozornost' (Bazovský 2017; Čambal 2017; Demetz 1999, 42-47; Garbsch 1985).

\section{Opasky}

Opasky zomrelých predstavujú dekoratívne garnitúry (Bytča 1 a Mikušovce 3) i pásy s jednoduchým zapínaním pomocou železnej zápony neskorolaténskeho pôvodu (Droberjar 2006, 32-35; Madyda-Legutko 1990, 159; Salač 2010, 362). Hrdlo ženy z hrobu Bytča 1 zdobil otvorený železný kruh ovinutý drôtom z cínovej kompozície, ktorý nemá presné paralely, aj ked' kovové nákrčníky patrili v tejto dobe k oblúbeným ozdobám. K ozdobám hrdla, ale aj opaska patrili sklené koráliky. Bronzové závesky, podobné nálezu z hrobu Mikušovce 3 boli značne rozšírené na neskorolaténskych sídliskách vrátane oblasti púchovskej kultúry (Benedikovál Pieta 2018b, obr. 4; Bazovský 2014, 166; Pieta 2014, 137, obr. 7: 12). Častou ozdobou boli prstene - jednoduché obrúčky alebo dlhodobo oblúbené drôtené prstene s posuvnými koncami Beckmann typ 16 (obr. 28: 4; Beckmann 1969, 34; Czarnecka 1989).

\section{Zrkadlá}

V dvojhrobe v Bytči-Hrabovom mali obe ženy za hlavou uložené zrkadlá z bronzovej zliatiny, z ktorých sa zachovali len kovové disky (obr. 6: 7; 7: 4). Pre problematiku sú zaujímavé časté vyobrazenia zrkadiel na norických náhrobkoch (Kvetánová 2006, 394, s literatúrou) a ich výskyt v germánskych hroboch včasnej doby rímskej, čo možno pokladat za prvok prevzatý z východoalpskej oblasti, najmä v kombinácii s kovovými súčastami tzv. noricko-panónskeho kroja (Adler 1976; Bemmann 1999, 165; Niezabitowska-Wiśniewska 2012; Schuster 2010, 179-185; Zeman 2017, 146, s literatúrou).

\section{Ďalšie kostrové nálezy v oblasti púchovskej kultúry}

Prvé včasnohistorické hroby boli na území púchovskej kultúry zistené ešte koncom 19. stor. na eponymnej lokalite Skalka v Púchove (Beninger 1937, 61, 62; Hoenning O'Caroll/Halaša 1903, 21, 22). Na základe archívnych dokumentov viaceré z najmenej siedmich odkrytých kostrových hrobov podla zisteného inventára (obr. 28) patrili do včasnorímskeho obdobia (Prohászka 2017). Ďalšie kostrové hroby z považských lokalít nie sú datované sprievodným inventárom, prípadne sa ich nálezové okolnosti nedajú spol’ahlivo overit' (Udiča-Okrut, Liptovská Sielnica-Liptovská Mara, Lysica).

\section{Kultové praktiky a pohreby na náleziskách púchovskej kultúry}

Hradiská v Bytči-Hrabovom a v Mikušovciach sú typickými lokalitami púchovskej kultúry. Množstvo nájdených projektilov i nálezové súbory vrátane hro- madných nálezov, ako aj absencia dokladov ich d’alšieho využívania sú sprievodným znakom ich násilného zániku na začiatku doby rímskej, ktorý je sledovaný na mnohých d’alších lokalitách tohto typu na celom území s osídlením púchovskej kultúry, ale najmä na strednom Považí (Pieta 2009). Ide o výrazný fenomén, ktorý bezpochyby odzrkadluje dramatické historické udalosti s významným dopadom na osídlenie celej západokarpatskej oblasti i širšieho priestoru stredného Podunajska. Hroby, zistené na oboch náleziskách ponúkajú nové možnosti výkladu procesu zániku púchovských opevnení a zároveň sú príspevkom k zložitej a dosial' neobjasnenej problematike pochovávania či kultových praktík v tejto oblasti i spoznávania etnicko-kultúrnych pomerov $\mathrm{v}$ časoch dramatických zmien v priebehu 1. stor. po Kr. v širšom priestore stredného Podunajska.

V stredoeurópskom priestore je vývoj pochovávania v rámci laténskej civilizácie pomerne dobre doložený. Ukladanie zomrelých na keltských radových pohrebiskách sa skončilo na konci stupňa C1. Pre neskorolaténske obdobie doklady pochovávania nie sú známe (Pieta 2018; Repka 2015). V horských oblastiach Slovenska od konca staršej či začiatku mladšej doby železnej až do počiatku stredoveku doteraz nie sú doložené hroby tamojšieho obyvatel'stva. Nositelia púchovskej kultúry podobne ako aj iné spoločenstvá laténskej civilizácie zrejme nahradením viery v posmrtný život predstavou o reinkarnácii stratili záujem o uctievanie či starostlivost’ o pozostatky mŕtvych (Pieta 1982, 191). Oheň ako sprostredkovatel kontaktov pozemského a nadpozemského sveta dominuje prevahe archeologicky i písomne doložených náboženských obradov doby laténskej včítane kultových miest v západných Karpatoch (Prosné - Pietal Moravč́k 1980; Slatina - Pieta 2018). Niekedy boli podla miestnej zvyklosti obetované zvieratá spalované a časti nespálených ludských tiel zasa ukladané do obetných jám (Liptovská Mara - Pieta 1982,198-201; Pieta/Stloukal 1991). Podl’a súčasného stavu bádania sa zdá, že masívna zmena v osídlení púchovskej kultúry, ktorá sa jasne črtá horizontom zničených hradísk s hromadnými nálezmi na začiatku doby rímskej znamenala aj určité prerušenie náboženských tradícií vrátane "ohňových“ rituálov. V Liptovskej Mare bola svätyňa v stupni LTD2 opustená a pri prestavbe opevnenia v stupni B1a už toto posvätné miesto s dlhou tradíciou nebolo rešpektované. Zdá sa však, že v niektorých regiónoch staré kremačné rituály prežívali aj nad’alej (Blatnica, Mošovce; obr. 30).

Kostrové hroby doby rímskej v oblasti naddunajského barbarika s jednoznačnou prevahou kremačného pochovávania sú zvláštnym, opakovane analyzovaným fenoménom (Bemmann/Voß 2007; Kvetánová 2008; Lichardus 1984; Pollak 1980, 11-13). Odlišnost̉ inhumačného pohrebného rítu bola vysvetlovaná rôzne: sociálnym postavením, inou kmeňovou príslušnost’ou, či vplyvom provinciálneho prostredia. Kostrové hroby v prostredí púchovskej kultúry, ako už bolo spomenuté, nevykazujú väzby na silne tradičné domáce prostredie, a to ani pohrebným rítom, a len čiastočne svojim kovovým inventárom. Kroj zomrelých jasne inklinuje k okruhu noricko-panónskych ozdôb, najmä spôn a opaskov, ktorý je, ako sa ukazuje, skôr tažko uchopitel'ným a značne variabilným „módnym“ trendom staršej doby rímskej než exportom uceleného štýlu odievania či zdobenia tak v provinciálnom, ako aj v barbarskom prostredí (Rothe 2013). 


\section{Závery}

Na začiatku doby rímskej došlo na území púchovskej kultúry k zásadným zmenám sídliskovej štruktúry, nepochybne spojeným s politickými turbulenciami a nepochybne aj s významnými etnickými presunmi. Pohyby v tomto smere naznačujú písomné správy, týkajúce sa vzniku nového mocenského fenoménu na západnom Slovensku - Vanniovho královstva a bojových kontaktov Kvádov a zakarpatských Lugiov. Súčastou týchto zmien bol aj nový fenomén opísaný $\mathrm{v}$ tejto štúdii - skupinky kostrových hrobov, v predpoliach výšinných opevnení. Nie je známe, či k pochovaniam došlo pred alebo po zániku hradísk, ktorý sa udial približne v rovnakom čase. Sú to hroby alebo neznáme rituálne pohreby? Umiestnenie v osídlenom priestore a na strmých svahoch pred opevnením vyvoláva predstavu, že nejde o štandardný spôsob pochovávania miestnej populácie, ako to naznačujú aj zranenia na hlavách žien z Bytče-Hrabového a možno aj hrot šípu pri kostre $3 \mathrm{v}$ Mikušovciach. Naviac, inhumačné pochovávanie (a pochovávanie ako také) nemalo na území púchovskej kultúry žiadnu tradíciu. V hroboch nájdené opaskové garnitúry a spony do určitej miery evokujú smer pôvodu týchto jedincov v prialpskej oblasti. Šírenie norického vplyvu na sever bolo možné sledovat už v nesko- rokeltskom osídlení západného Slovenska, čo sa prejavuje vo viacerých aspektoch materiálnej kultúry, mimo iného aj šírením viacerých typov keramiky z východonorickej oblasti na západné Slovensko (Čambal et al. 2014, 67; Pieta 1996, 190; 2010, 54; Pieta/Plachá 1999, 200, 201). Ešte zretel'nejšie možno kontakty s juhom sledovat v rozšírení mincí z Panónie či Norika, ktoré sú evidované aj na púchovskom území, avšak prevažne len v jeho západnej časti, ktorá sa odvíjala do istej miery odlišne od centrálnej časti púchovskej kultúry.

Začiatkom doby rímskej noricko-panónsky „štýl“ v podobe atraktívnych doplnkov ženského kroja prenikol do rozsiahlych priestorov vrátane územia púchovskej kultúry. Touto cestou sa z formujúceho sa provinciálneho prostredia hypoteticky mohol na Považie dostat nielen kostrový rítus, ale možno aj príslušníci, či príslušníčky nového obyvatel'stva, prenikajúceho (azda ako súčast' novej kolonizačnej vlny, ktorú zavŕšil príchod Kvádov na západné Slovensko) do uvolneného priestoru osídlenia západnej časti púchovského územia, v tom čase oslabeného vojnovými udalostami (plošné zničenie púchovských hradísk). V súčasnosti podobné hypotetické úvahy, pri vhodnom biologickom materiáli, pomáhajú efektívne riešit’ analýzy izotopov stroncia a DNA. ${ }^{3}$

\footnotetext{
2 Analýza osteologického materiálu z hrobov v Bytči-Hrabove a v Mikušovciach v laboratóriu R. Pinhasiho, Universität Wien
} pripravuje S. Sawyer. 